\title{
A STUDY IN CONSTITUTIONAL RIGIDITY. II*
}

\author{
Kenneth C. Sears † and Charles V. Laughitn $\ddagger$
}

Mississippi-Since the publication of the first instalment of this article, additional information concerning Mississippi has been examined. It is therefore necessary to revise and to some extent correct the previous discussion concerning that state..$^{25}$

The present constitution of Mississippi was adopted in 189o. Section 273 provides for amendments. The essential requirements are: (I) that a proposed amendment shall be passed by a two-thirds vote of each house; (2) that it shall be submitted at "an election," at which the people may vote for or against each amendment separately; and (3) that if "a majority of the qualified electors voting shall have voted for the proposed change," then it shall be inserted as a part of the constitution at the next succeeding session of the legislature. ${ }^{\mathrm{x} 26}$

As far as is known there has been no interpretation by the Mississippi courts of the expression "an election." Apparently, this would permit the legislature to pass an act that would provide for the submission of constitutional amendments at a specifically designated special election. Mississippi has, despite its population of about two million, a very small and select group of voters at the general November elections in the even-num-

* Párt II of an article, of which Part I appeared in the January, I943, issue of this Review. See ro Univ. Chi. L. Rev. 142 ( 1943 ). This article is based upon original research by Charles V. Laughlin. Owing to Mr. Laughlin's induction into the military service in September, I942, before the article was in an appropriate form for publication, revision thereof was undertaken by Professor Sears. This process of revision entailed additional research, and much of the text was largely re-written. It is at Mr. Laughlin's instance that the primary credit for authorship is attributed to Professor Sears.

$\dagger$ Professor of Law, University of Chicago.

$\ddagger$ Of the Illinois Bar.

$\$ 26$ "Whenever two-thirds of each house of the legislature shall deem any change, alteration or amendment necessary to this Constitution, such proposed amendment, change or alteration shall be read and passed by two-thirds vote of each house, respectively on each day, for three several days; public notice shall then be given by the secretary of state at least three months preceding an election, at which the qualified electors shall vote directly for or against such change, alteration or amendment, and if more than one amendment shall be submitted at one time, they shall be submitted in such manner and form that the people may vote for or against each amendment separately; and if it shall appear that a majority of the qualified electors voting shall have voted for the proposed change, alteration or amendment, then it shall be inserted at the next succeeding session of the legislature as a part of the Constitution and not otherwise." Miss. Const. art. 15, $\$ 273$.

As to the meaning of the expression "passed by two-thirds vote of each house" see the interpretation of a similar expression in the constitution of 1832 . Green v. Weller, 32 Miss. 650, 33 Miss. Appendix (I856). 
bered years. This has been particularly true in the years when a president was not elected. There has been no great difficulty in adopting amendments in these even-numbered years. Accordingly, there has been, apparently, no pressure to provide for the submission of amendments at a specifically designated special election, where only those interested in voting on amendments would vote. If, in the future, it should happen that the voters at the general November elections in the even-numbered years should increase so that they would be comparable in number to the voters in general elections in northern and western states, then it is posssible that Mississippi might have trouble in adopting amendments. If so, the device of a specifically designated special election could be tried as a remedy. In the meantime, it is to be remembered that Section Ioz of the Mississippi constitution provides that "all general elections for state and county officers shall commence and be holden every four years, on the first Tuesday after the first Monday in November, until altered by the law." But this section does not provide that state and county officers shall be elected in evennumbered years. And the Mississippi statutes provide that state and county officers, all of them, apparently, except judges, shall be elected in odd-numbered years. ${ }^{127}$ Thus, it would appear that the only officers elected in November in the even-numbered years are the presidential electors, members of the Congress, and state judges. ${ }^{\mathbf{x} 8}$ Since Mississippi has been invariably Democratic since reconstruction days, it is easy to understand why the vote has been very small in the elections at which constitutional amendments have usually been submitted, since 1890 .

In a section dealing primarily with other requirements, these two sentences were found: "Constitutional amendments shall be voted for at the time fixed by the concurrent resolution. The election, whether held separately or with other elections, shall be conducted, in all respects, as required for elections generally." ${ }_{22}$ "The" concurrent resolution apparently means the resolution which is used to pass the proposed amendment through the legislature and submit it to the electors. These resolutions have usually provided for a vote in the even-numbered years at the gen-

${ }^{22}$ Miss. Code Ann. (I942) $\$ \S 3237,3238$. In exceptional cases, apparently, municipal elections have occurred on the second Tuesday in November in even-numbered years. Occasionally this has been the same day as the first Tuesday after the first Monday. Miss. Code Ann. (1930) § 2597. Cf. 1938 Supplement, ch. 50, Sec. 273, and Miss. Code Ann. (I942) § 3764 .

${ }_{228}$ Miss. Code Ann. (r942) $\$ \S 3297$ (electors chosen during presidential year), 3302 (representatives in the Congress every even-numbered year), 3307 (U.S. senators), 33I0 (judges of circuit and chancery court districts), $33 \times 3$ (judges of the supreme court). Cf. Miss. Const., Art. 5, $\S 243$.

129 Miss. Code Ann. (I942) $\S 3280$. 
eral election on the first Tuesday after the first Monday in November. The two sentences quoted tend to confirm the suggestion made previously that in Mississippi amendments can be submitted at a specifically designated special election, if the legislature should so desire. However, it would appear that the general November election in the even-numbered years in Mississippi is not a contested election in any ordinary sense of that expression. This is due to the severe restrictions on voting, ${ }^{130}$ and generally to the fact that for practical purposes Mississippi is a one-party state. The real contests occur in the primaries and the run-off primaries. ${ }^{{ }^{3}{ }^{\mathrm{I}}}$ So.it would seem at least reasonably accurate to conclude that the only actual contest in the elections at which constitutional amendments are submitted is that which arises over the adoption of the amendments. The Democratic candidates are regarded as certain to be elected. Herein lies one striking difference between Mississippi and Tennessee. In effect, elections in Mississippi, at which constitutional amendments are either adopted, not adopted, or defeated, are to a very large extent special elections. And this seems to be the main explanation for the success that Mississippi has had in amending its constitution.

Section 273 of the Mississippi constitution as adopted in 1890 provides that if an amendment of it is ratified by the voters "it shall be inserted by the next succeeding legislature as a part of this constitution, and not otherwise." But this would appear to be a judicially non-enforcible constitutional provision. If so, the "next succeeding legislature" can defy the wishes of the voters and nothing can be done about it. In the Mississippi Code (I930) and in the Annotated Code (I942) there appears this annotation to Section ro5 of the constitution: "An amendment eliminating the foregoing section was submitted to the people by the legislature at the session of I894, see Laws I894 ch. 43; an election was held in November, I894, and seems to have resulted in favor of the elimination of the section, but no action was taken by the legislature after the election." As a result, Section I05 is still printed as a part of the Mississippi constitution.

The Mississippi legislature in 1898 submitted two amendments. One of them concerned the powers of the commissioners of levee districts, and the result is recorded in Table $8 .{ }^{132}$ The other proposed to eliminate five sections of the constitution and adopt one section in lieu thereof. The purpose

${ }^{130}$ Miss. Code Ann. (1942) $\$ \S 3235,3236$.

${ }^{x 3}$ Miss. Code Ann. (ז942) $\S \S 3$ rog-3rxx. In r940 Roosevelt received $x 68,252$ and Willkie 7,364. World Almanac 785 (1942).

${ }^{{ }^{132}}$ See Io Univ. Chi. L. Rev. $x_{72}$ (r943). According to Mississippi, Laws, I900, p. 238, the affirmative vote was 14,515 , instead of 14,516 , an immaterial difference. 
was to provide for an elective, instead of an appointive, judiciary. It was provided, however, that this proposal should be submitted at the November, $x 899$, election instead of the November, 1898 , election. ${ }^{{ }^{333}}$ It was apparently adopted, according to a resolution to insert it into the constitution, by a vote of $2 I, I 69$ for to 8,643 against. ${ }^{134}$ But it was decided in State v. Powell ${ }^{135}$ that this amendment was invalid, because there were at least four amendments submitted as one proposition, in violation of Section 273 of the Mississippi constitution. It was also decided that the amendment had not been ratified by the necessary majority. It was stated in the defendant's plea, apparently accepted as correct in view of the demurrer to the plea by the state, that the amendment received 2I,I69 votes, to 8,643 against it, but that in the same election there were 48,370 votes cast for governor. Thus, the vote for the amendment was less than half of the vote for governor, to say nothing of the total vote at the election. The supreme court interpreted the $\mathrm{r} 890$ constitutional provision that an amendment is adopted "if it shall appear that a majority of the qualified electors voting shall have voted for the proposed" amendment to require a majority of the total number voting at the election for any purpose even though the I 890 requirement was different from the provisions in the three preceding Mississippi constitutions. The last two had required a majority of those voting "for members of the legislature." The omission of the quoted words from the 1890 constitution not only had not weakened the requirement, but, as the court said, had "absolutely strengthened" it.

The Ig04 legislature submitted a constitutional amendment to elimi-

${ }^{133}$ Mississippi, Laws, Spec. Sess., 1898 , chs. 83,84 , pp. $97,98$.

${ }^{234}$ Mississippi, Laws, I900, ch. I99, pp. 236-237. The total vote was not stated in the resolution to insert.

${ }^{235} 77$ Miss. 543, 27 So. 927 ( 1900$)$. Accordingly, the second item in table 8 under the date of r 900 should be regarded as corrected as herein indicated.

The Mississippi legislature in its $19 \infty 0$ session submitted two amendments to the voters at the November, rgoo, election. One concerned the disposition of the poll tax, and the other provided for a new apportionment of senators and representatives. Mississippi, Laws, 1900, pp. 239-24x. These amendments were not inserted "at the next succeeding session of the legislature" as now provided by Section 273 of the Mississippi constitution; but they were inserted by the rgo4 session, and apparently this was in conformity with Sections 36 and 273 of the constitution as then worded. The resolution to insert stated that the first one received 43,128 votes for and 7,733 against, and that the amendment had received " $a$ majority of all the legal votes polled at said election." The resolution to insert the second amendment stated that the total vote cast at the election was $5 \mathrm{r}, 238$; that the vote for was 32,295 and the vote against was 6,9I7; and that "the same was carried by a majority of 2,744 of all the legal votes polled at said election." The latter part of the quoted statement seems erroneous. Instead of the amendment having a majority of 2,744, it would appear to have had 6,675 more votes than necessary for it to be ratified. In any event both amendments seem to have been adopted and actually inserted. Mississippi, Laws, 1904, pp. 223-226. Neither is included in Table 8. 
nate Section I05 of the constitution. ${ }^{\mathrm{r}}{ }^{6}$ No record concerning this amendment has been found in later session acts: The normal inference from this would be that the proposed amendment was either defeated or not adopted, and Section ro5 still appears to be a part of the printed constitution. ${ }^{{ }^{23}}$

In I908 an amendment concerning the grant of donations was inserted into the constitution. It was duly submitted in 1906 and the Ig08 legislature asserted that it had received $I 5,425$ votes, to $I, 267$ against it, and that it had "received a majority of all the legal votes polled at said election." The total vote at the election was not set forth. ${ }^{{ }^{13} 8}$

The legislature of $x 908$ submitted an amendment to provide for the insertion of ratified constitutional amendments "at the next succeeding session of the legislature" rather than "by the next succeeding legislature." ${ }_{\mathbf{x}_{39}}$ Since no record of this proposal has been found in later session acts, it will be assumed that it was either defeated or not adopted.

The Supreme Court of Mississippi in IgI3 held that the amendment submitted in Igro to provide for the election, rather than the appointment, of circuit and chancery court judges had been properly submitted and adopted even though the amendment could have been divided into two amendments, one providing for circuit court judges and the other providing for chancery court judges. The court, in State v. Jones, expressly refused to follow State v. Powell ${ }^{\mathrm{x} 4^{\circ}}$ to this logical but absurd extreme..$^{\mathrm{I} 4 \mathrm{I}}$

The initiative and referendum proposal of $\mathrm{Ig} \mathrm{x}_{4}$ is listed in Table 8 as "not adopted." This proposal was the subject of considerable litigation. In Power v. Ratliff ${ }^{x^{42}}$ the Mississippi Supreme Court refused to enjoin the secretary of state from proceeding under the amendment to submit to the voters in the I $9 \mathrm{r} 6$ election certain acts of the legislature for their decision under the referendum provision. It held that there was no jurisdiction in the court, but intimated no opinion as to the validity of the amendment.

In State v. Brantley ${ }^{\mathrm{T} 43}$ the initiative and referendum amendment was again challenged. But in a per curiam opinion the supreme court, Sykes, J., dissenting, merely held that a statute was not in effect. This statute

${ }^{236}$ Mississippi, Laws, I904, ch. $x 7 x$, p. 223. This amendment is not listed in Table 8.

${ }^{137}$ See the discussion, supra, concerning this same section and the amendment submitted in 1894 .

${ }^{138}$ Mississippi, Laws, I906, ch. 238 , p. 277 . Ibid., I908, ch. I49, p. I68. This amendment is not listed in Table 8.

${ }^{139}$ Mississippi, Laws, I908, ch. 286, p. 259. Cf. Miss. Ann. Code, 1892, Section 273 of the constitution. This amendment is not listed in Table 8.

$14^{\circ}$ See note 135 supra.

${ }^{\text {I4x }}$ I06 Miss. 522, 64 So. 24I (I9I3).
${ }^{142}$ Ir2 Miss. 88,72 So. 864 (Igr6).

${ }^{143}$ I13 Miss. 786,74 So. 662 (I917). 
had been referred, and the majority vote was against it. But the members of the court were not agreed "upon any one reason that should be assigned" for their decision.

"On suggestion of error," Smith, C. J., later wrote an opinion for a majority of the court. He answered the argument that the initiative and referendum amendment was invalid because (I) it had failed to receive a majority of the votes cast at the November I9I4 election and (2) because the amendment contained more than one proposition. His first answer was in part:

.... that the original election returns transmitted to the secretary of state by the election commissioners of the various counties disclose that $\mathrm{I9,}$,II 8 votes were cast in favor of the amendment, 8,718 against it, and that the highest vote cast for any officer voted for at the election was 37,583 , but do not disclose the total number of votes cast at the election, unless all of the voters voted for the officer receiving the highest number of votes. After the receipt of these returns, the secretary wrote a circular letter to the election commissioners of each county, requesting them to reconvene and ascertain and certify to him the total number of votes cast in each county, with which request the election commissioners of all but six counties complied by certifying to the secretary of state, not the number of votes counted by them in ascertaining the result of the election, but the number of qualified electors who deposited ballots in the ballot boxes as appeared from the list thereof made by the clerk of the election as each ballot was deposited. The number of such qualified electors was 40,070 . If the amended returns are to govern, the amendment was rejected; and if they are not, it was ratified.

Then he stated that "the amended returns are of no value here; for they show, not the number of 'qualified electors voting,' but simply the number thereof who appeared at the polls and deposited ballots, legal or otherwise, in the ballot boxes, which ballots may or may not have been counted by the managers or commissioners in ascertaining the result of the election." Consequently, Judge Smith relied upon previous legislative practice and upon a presumption "that the highest number of votes cast for any officer represents the total number of votes cast at the election."

Smith, C. J., for the majority, also disagreed with the second argument. He followed "the liberal and common sense" interpretation in State v. Jones, and refused to return to "the strict and narrow interpretation" in State v. Powell. Thus, it was concluded that the initiative and referendum amendment was properly inserted in the constitution.

Sykes, J., in dissenting, differentiated the Powell and the Jones cases, and asserted that the amendment under consideration in this case was unconstitutional because it was a "double amendment" submitted as one. Holden, J., also wrote a dissenting opinion. He agreed with the point of view stated by Judge Sykes. He also dissented because "a majority of the 
qualified electors voting at the election did not vote for it," i.e., the initiative and referendum amendment. He believed that the amended returns established "the truth to be that 40,070 votes were cast at the election." ${ }^{4} 44$ Judge Holden, however, arrived at this conclusion in this manner:

The effort of the majority opinion to discredit or undervalue these amended and complete returns can find no support in reason or authority. The certified voting list showing the registration of the names of the voters and that they voted by putting their ballots in the box, is presumptive, and even conclusive, evidence of the total number of votes cast at the election, and should prevail, unless the presumption is rebutted and overcome by evidence to the contrary.

The clash between Smith, C. J., and Holden, J., on the proposition of the "majority of the qualified electors voting" comes down to this: Smith, C. J., relied on one presumption, while Holden, J., relied on another presumption. Neither presumption seems to be in accord with voting experience. Both appear to be artificial. Which should be preferred seems to be a toss-up. Smith's presumption is the liberal one; it makes the process of amending somewhat less restrictive, and it appears to be clear that Smith, C. J., had that type of mind. Holden's presumption makes for a greater restriction on amendment and for a more rigid constitution. It is clear that Holden, J., had the latter type of mind. To him the Mississippi constitution was "that sacred instrument." He had very strong emotions against the initiative and referendum amendment. He feared that it would seriously impair "a government by the white man." In the opinion written by Sykes, J., dissenting, there also appears language that seems to have the same meaning.

In the Mississippi election of I9I4, nine proposed amendments were submitted to the voters. Seven of them were adopted by a majority of the 40,070 votes, the total vote cast according to Judge Holden. The initiative and referendum amendment received a yes vote of 19,118 , which was less than a majority of this total vote. So, Judge Holden was of the opinion that it had not been adopted. But what about the ninth amendment, for reapportionment of senatorial districts? It received a yes vote of only

${ }^{144}$ No mention was made of the statement by Smith, C. J., that the election commissioners of six counties failed to fle corrected returns.

In State v. Jackson, rrg Miss. 727, 8I So. I (IgIg), both the majority and the minority opinions assume that the initiative and referendum amendment had become a part of the Mississippi constitution.

Minnesota has also had trouble in determining the total vote cast at any election due to the presence of illegal, blank, and unintelligible ballots. Hopkins v. Duluth, 8I Minn. I89, 83 N.W. 536 (I900); Lodoen v. Warren, I I8 Minn. 37I, I36 N.W. ro3I (rgr 2); Eikmeier v. Steffen, I3 I Minn. 287, I55 N.W. 92 (I9I5); Godward v. Minneapolis, rgo Minn. 5I, 250 N.W. 7 I9 (I933). 
I9,249. Judge Holden made the argument that the Mississippi legislature in I9I6 inserted the first seven amendments in the constitution, and in doing so, asserted that each of them had received a majority of the qualified electors voting at the November, I9I4, election. He also stated that the legislature made the same assertion concerning the reapportionment amendment; but this statement is contrary to the record. Instead, the legislative assertion was this: ". . . . that nineteen thousand two hundred and forty-nine votes were cast in favor of said amendment, and eight thousand six hundred and fifty votes were cast against said amendment; said amendment having received a majority of all the legal votes polled at said election: Therefore," etc. ${ }^{\mathrm{I} 5}$ Judge Holden insisted that the initiative and referendum amendment had failed because it had not received at least 20,036 votes. But he did not suggest that the reapportionment amendment had failed for the same reason. On the contrary, he seems to have accepted the legislative assertion concerning it, i.e., it had received "a majority of all the legal votes polled." Judge Holden emphasized the different sort of statement made by the legislature in the resolution inserting the initiative and referendum amendment, viz.: “.... I9,Ir8 votes were cast in favor of said amendment, and 8,718 votes were cast against said amendment"; therefore be it resolved that said amendment is inserted in the constitution..$^{x 6}$ Unless there is a vital difference between the expression "a majority of the qualified electors voting" and the expression "a majority of all the legal votes polled," then the legislative assertion concerning the reapportionment amendment was patently false. Yet, the reapportionment amendment is a part of the Mississippi constitution. ${ }^{147}$ This probably proves that it was not a dangerous amendment; but it is plain that the initiative and referendum amendment aroused great fears in some white Mississippians.

In the September term, I922, in Power v. Robertson, the Supreme Court of Mississippi reversed its decision in State v. Brantley, and held that the initiative and referendum amendment was not a part of the state constitution, and that the amendment contained distinct subjects, which were improperly submitted as a single amendment. Judges Ethridge and Cook changed the votes they had cast in the Brantley case. Judges Holden and Sykes agreed with them, and Judge Anderson, a new judge, agreed with these four. That left only Judge Smith to dissent and thus retain the position that he had previously taken. There was no comment in

${ }^{245}$ Mississippi, Laws, I916, ch. I60, p. 221.

${ }^{246}$ Mississippi, Laws, I916, ch. I59, p. 218.

${ }^{147}$ See Miss. Const. Art. I3 $_{3} \S 255$. 
Power v. Robertson on the debated question whether the initiative and referendum had received sufficient votes for adoption, except that Judge Holden repeated his belief that the amendment had not been adopted "by a majority of the qualified electors yoting at the election." ${ }_{548}$

An amendment to provide for the terms of office and for the election, rather than the appointment, of levee commissioners by the governor was submitted to the voters in I920. Table 8 shows that this amendment was "not adopted." But the Mississippi legislature in February, I922, before Power v. Robertson was decided, adopted a resolution that this amendment had received $33,236^{\mathrm{x} 49}$ votes to 26,743 against it and that "having received a majority of the qualified electors voting for or against the same" it was inserted in the constitution..$^{50}$ This conduct was followed by a request that the supreme court overrule the second holding in State v. Powell, as discussed above. The court refused to do this and adhered to the view that an amendment fails of adoption, if it fails to receive a majority of the qualified electors voting at the election, even though it receives a majority of those voting on the amendment. Then it was argued that there was no provision in the Mississippi law "whereby the total vote cast at the election may be determined." The court answered this by purporting to quote from State v. Brantley as follows: "In the absence of a correct certification of the number of electors voting at an election at which a constitutional amendment is voted upon, the court must presume that the highest number of votes cast for any officer or measure represented the number of votes cast at the election." "Isx Accordingly, it was held that the levee-commissioner amendment was not adopted. Yet; marvelous to state, this amendment appears as part of the Mississippi constitution, ${ }^{152}$ despite the

${ }_{148}$ I30 Miss. I88, 93 So. 769 (I922). This decision makes the statement in Table 8 that the initiative and referendum was not adopted technically correct, but not for the reason assumed in Table 8. The statement concerning the reapportionment amendment, discussed supra, is erroneous, if we accept the legislative action concerning it. Apparently the supreme court has never ruled upon the latter amendment.

Table 8, under the year I9I8, lists the vote on an amendment to change the qualifications of the governor. This amendment could not be located. Was it submitted under the initiative before the initiative amendment was held not to be a part of the constitution?

${ }^{149}$ The figure in Table 8 is 32,236 , but this may be an error which for the purposes here considered is immaterial. In State v. Cato, I3 ${ }^{\mathrm{r}}$ Miss. 7 Ig; 95 So. $69 \mathrm{I}$ (I923), yet other figures are given; viz: 82,380 , the "total" vote; i.e., "the highest number of votes cast for any candidate or measure voted for at such election"; 33,238 for and $26,79 x$ against the amendment.

${ }^{250}$ Mississippi, Laws, 1922 , ch. 155 , p. $x 4$.

${ }^{251}$ Apparently, instead of quoting exactly from the overruled opinion of the majority in State v. Brantley, supra note 143 , the court quoted a headnote in the very case in which the opinion was written; viz., State v. Cato, supra note 149 .

${ }^{152}$ Miss. Const. Art. II, $\S 23$ I. This has been corrected in Miss. Code Ann. (1942) Const., Art. II, \$23r. 
fact that another amendment of this same Section $23 \mathrm{r}$ was submitted in I924 and defeated, ${ }^{153}$ and despite the further fact that practically the same amendment was again submitted in $1926^{\mathrm{r} 54}$ and adopted and then formally "inserted" in $1928 .{ }^{155}$ It seems, in conclusion, to be a fair comment that attempting to determine the total number of voters in the evennumbered years at the November elections has caused confusion in Mississippi and that the state would have been served better if it had been held that under Section 273 of the I89o constitution an amendment could be adopted by a majority of those voting on a particular amendment. ${ }^{156}$

Nebraska-The history of the amendment of the Nebraska constitution is of unusual interest. Its constitution of 1875 provided that proposed amendments to the constitution "shall be submitted to the electors for approval or rejection" at "the next election of senators and representatives." It also provided that "if a majority of the electors voting at such election adopt such amendments, the same shall become a part of this constitution."'157

This constitutional provision was interpreted by the Nebraska Supreme Court to mean that an amendment was not adopted even though it received a majority of those voting on the amendment, when the number voting for the amendment was less than a majority of those voting at the general election for senators and representatives. ${ }^{\mathrm{x} 8}$ Under this interpreta-

${ }_{53}$ Mississippi, Laws, x924, ch. I44, p. I9r. See Table 8, supra.

${ }^{154}$ Mississippi, Laws, 1926, ch. 200, p. 3 II. See Table 8, supra.

${ }_{155}$ Mississippi, Laws, I928, ch. 356 , p. 45 r. At the same session an amendment to Section 229 was inserted in the constitution, and yet it does not appear in the constitution printed in the Mississippi Code for r93o. Perhaps someone who is more familiar with the Mississippi legal system can explain these apparent contradictions. Correction has been made in Miss. Code Ann. (I942) Const., Art. II, § 229.

${ }^{r 56}$ Mississippi, Laws, 1930, ch. 290, p. 730, sets forth a proposed amendment to Section 2 II of the constitution to be submitted in November, 1930. This is not recorded in Table 8 , and no further record concerning it has been found. It if was submitted, it was presumably defeated or not adopted.

A similar statement is proper concerning a proposed gross income or gross sales tax, submitted in 1936. Mississippi, General Laws, I936, ch. 353, p. 622.

In 1938 two amendments were proposed. They were voted upon at the November, r939, election. On one, the vote was 57,326 for to 4,888 against; on the other, 58,354 for to 4,847 against. The total vote was not stated; but in one case it was asserted by the legislature that the amendment had received a majority "of all the legal votes polled" and in the other case "a majority of the legal votes polled." Both were formally inserted, even though one merely repealed an existing section of the constitution. Mississippi, Laws, Ex. Sess., 1938, ch. 94, 95,

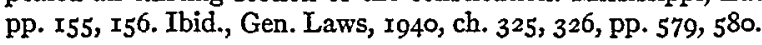

${ }^{257}$ Neb. Ann. Stat. (Cobbey's, I9II) Article XVII, § I.

${ }^{15^{8}}$ State v. Babcock, 17 Neb. 188,22 N. W. 372 (1885). These were the assumed facts in the case: 134,000 votes were cast for governor and other state officers; 132,000 for senators and representatives; $5 \mathrm{x}, 959$ in favor of the constitutional amendment; and 17,766 against it. Would it have been sufficient if the favorable vote on the amendment had been one-half of 
tion. Nebraska found it very difficult to amend its constitution. Of the twenty-two amendments submitted from 1882 to 1896 , inclusive, only one was adopted. ${ }^{159}$ Four were defeated because they received fewer affirmative votes than negative votes. The remaining seventeen were not adopted even though they received more affirmative votes than negative votes.

Faced with this situation, the Nebraska legislature, contrary to the Illinois General Assembly, determined to solve its problem. Accordingly in I $90 \mathrm{I}$ it amended a number of sections of its election laws and provided: "A state convention of any political party may take action upon any con. stitutional amendment, which is to be voted upon at the following election, and said convention may declare for or against such amendment, and such declaration shall be considered as a portion of their ticket to be filed with the Secretary of State and by him certified to the various county clerks." "r6o It also enacted other provisions to make its main purpose effective, and then it provided that if a voter "wishes to vote a straight party ticket he shall make a cross in the circle at the right of the name of his party at the head of the ballot, and his vote shall be considered as a vote for every candidate and endorsed constitutional amendment of that party on the ballot."I6r Then followed a provision by which a voter need not vote a straight

I32,000 plus $x$ ? Or would it have been necessary for the amendment to have secured one-half of 134,000 plus $\mathrm{I}$ ? In the majority opinion there is languague that appears to assert both points of view. Therefore, it would seem that the court did not carefully discriminate between the two positions. Compare Rosewater, A Curious Chapter in Constitution-Changing, 36 Pol. Sci. Q. 409, 4II (Ig2I), with the majority opinion in Tecumseh Nat'l. Bank v. Saunders, 5I Neb. $80 x, 805-806,7 \mathrm{r}$ N.W. $779,78 \mathrm{r}(\mathrm{I} 897)$, where the second position is asserted to be the correct interpretation of the constitution: "to secure the adoption of an amendment to our constitution it is necessary that the favorable votes be in excess of one-half of the highest aggregate number of votes cast at said election, whether such highest number be for the selection of an officer or upon the adoption of a proposition." Norval, J., in agreeing with this part of the majority opinion, expressed this regret: "Taking the past as a criterion by which to foretell the future, it would seem, under the construction adopted, it will be almost, if not quite, impossible to change the present constitution, however meritorious may be the amendment proposed." Tbid., at 8I6 and 785. See State v. State Election Board, 18r Okla. 622, 75 P. (2d) $86 x$, for pertinent comments on this Nebraska opinion.

${ }^{159}$ With reference to this one adopted amendment it has been stated: "After having been lost once, this was rescued and declared adopted upon re-submission two years later, thanks to the dubious expedient of a 'recount,' the recount being made with liberal allowances by the lawmakers who were to be the beneficiaries." Rosewater, op. cit. supra note 158 , at $4 \mathrm{Ir}$. See, also, Sheldon, I5 Am. Pol. Sci. Rev. 39 I (I92I).

${ }_{360}$ Neb. L. (IgOI) c. $29, \S 3$.

${ }^{16 x}$ Neb. L. (I9OI) c. $29, \S 7$. It should be observed that these laws of Igor made provision for constitutional amendments. No mention of calling a constitutional convention appears. See also Section II, setting forth the instructions to voters, and Section I2, setting forth the form of the official ballot that includes the mechanics by which party-circle voting on constitutional amendments was made effective. Observe that the party circles are at the top of the blanket ballot and that the constitutional amendments are at the bottom. 
ticket and also a provision by which a voter might vote a straight party ticket with exceptions as to particular candidates or a particular constitutional amendment.

In 1903 Sections I 40 and I60 of Chapter 26 , which had been amended in IgOI, were again amended. These amendments provided that "questions to be submitted to the vote of the people" should be "printed above the names of all candidates, and below the space for a straight party vote" upon the regular blanket candidates' ballot. The only expressions on the ballot under the 1903 amendment that were above the constitutional amendments were the title of the ballot and the names of the political parties which had candidates for office, followed in each instance by a party circle. And above these party circles was this instruction: "To Vote a Straight Ticket make a Cross within Your Party Circle." "ro

In 1904 there was submitted to the voters of Nebraska a proposition for calling a constitutional convention. This proposition was not adopted since 75.7 per cent of the voters did not vote on the proposition. Victor Rosewater, in his article entitled "A Curious Chapter in ConstitutionChanging," stated: "By oversight, probably, it [the party circle law] was not employed in connection with the amendment submitted in Nebraska in I904, no action being taken by the party conventions of that year."'163 It is submitted that Rosewater, even though a resident of Nebraska, made two errors in this statement. In the first place, an amendment was not submitted in I904. It was a proposition to call a constitutional convention. ${ }^{{ }^{64}}$ In the second place the Nebraska laws at that time did not permit partycircle voting on a proposition to call a constitutional convention, even though the statutory amendments passed in 1903 to a certain extent squinted in that direction. ${ }^{165}$

The party-circle law was used successfully in $1906 .{ }^{166}$ In 1907 the Nebraska legislature enacted a primary election law. Section 35 of this law provided that all proposed constitutional amendments should be printed on the primary election ballots of all political parties, "and each elector may declare himself in favor of or against any such amendments the same as at such general election." It was also provided in this section that "If a majority of the electors of any party voting upon such amendment shall declare in favor of or against any such amendment, such declaration shall

${ }^{162}$ Neb. L. (Ig03) c. 4I.

${ }^{163}$ Rosewater, op. cit. supra note ( $\left.15^{8}\right)$, at $4{ }^{13}$.

${ }^{166}$ State v. Winnett, 78 Neb. 379,395 , I IO N.W. III3, III8-I9 (I907): "We conclude that the constitutional amendment in question has been regularly adopted and has become a part of the constitution of the state. ...." 
be considered as a portion of the ticket of such party." ${ }^{207}$ Thus it was that the legislature combined the party-circle law and primary-election law. Constitutional amendments were first submitted to the voters in the primary, and then to the voters in the general election that followed. A voter in the general election, if he voted without limitation in the party circle, voted for or against each proposed constitutional amendment as a majority of the voters in the primary in his party had voted. Under this scheme, Nebraska, with a single exception, ${ }^{x 68}$ succeeded in adopting all proposed constitutional amendments until the election of I9I4. In that election the three constitutional amendments submitted by the legislature were indorsed in the primary election by a majority of the voters in the six parties. Yet they failed to secure a majority of the total vote in the general election which followed. The reason for this reversal of form is not clear. One may guess that it was due to the unpopularity of one of the three amendments, which proposed a progressive income tax. The voting in other states which have been considered in this article supports the theory that one may expect difficulty if a taxation amendment is submitted to the voters. Why the opposition did not manifest itself in the primary yoting is a question. Perhaps it took time and agitation to change the usual complacency of the voters to an attitude of opposition. The significant thing in the I9I4 vote in the general election was the large increase in the percentage of the negative vote. This would indicate a positive conviction against at least one of the amendments proposed by the legislature in r9r4. There was also in I914 an amendment in favor of woman suffrage proposed by the initiative process. It is rather significant that this amendment for woman suffrage was defeated, i.e., it received more negative than affirmative votes. Apparently, therefore, this amendment was an unpopular one at that time, and together with the income-tax amendment may have placed the voters in the frame of mind to oppose all propositions at the Igr4 election. The most significant conclusion to be drawn from the I9I4 experience in Nebraska is that while the party-circle method of voting on constitutional amendments is an immense advantage, still there is nothing inevitable about it. For three amendments indorsed by all parties and submitted under the party circle were not adopted. And a fourth amendment submitted without the aid of the party-circle device was defeated. This party-circle device should, therefore, be contrasted with the

${ }_{167}$ Neb. L. (1907) 52, §35.

${ }^{168}$ The failure of this amendment to be adopted in rgro appears to be due to the fact that it was defeated in the Democratic primary even though it carried in the primary voting of the other four parties. See Rosewater, op. cit. supra note 158 , at 416 . 
device used in Alabama to adopt the "Birmingham Amendment" proposed by the Cook County Judicial Advisory Council in Illinois. ${ }^{170} \mathrm{It}$ does not appear that an amendment submitted under this latter device could fail of adoption short of a political revolution. It will be observed that in Nebraska in r9r4 those not voting on the party-circle amendments constituted more than 30 per cent of the total number of voters. But there will be no nonvoters, whenever the Alabama and Illinois device is used.

In Igr 2 the Nebraska constitution was amended to provide for the initiative and referendum. While this amendment was adopted by using the party-circle method of voting, nevertheless the amendment as adopted provided that: "All such measures [initiative or referendum] shall become the law or a part of the constitution when approved by a majority of the votes cast thereon, provided, the votes cast in favor of said initiative measure or part of said Constitution shall constitute thirty-five per cent (35\%) of the total vote cast at said election, and not otherwise." $77^{x}$ This 35 per cent provision made it more difficult, in theory at least, to adopt a constitutional amendment by the initiative than to adopt with the help of the party-circle device a constitutional amendment which had been proposed by the legislature.

The constitutional amendment containing the initiative and referendum also provided that "all propositions submitted in pursuance hereof shall be submitted in a non-partisan manner and without any indication or suggestion on the ballot that they had been approved or indorsed by any political party or organization."'172 While this language does not directly forbid the use of the party-circle method of voting on initiated constitutional amendments, that seems to be the purpose of the language. It appears also that such was the administrative construction of the language, because initiated constitutional amendments were not submitted to a vote in the party primaries under the law of $1907 .{ }^{173}$

After the initiative and referendum amendment was adopted in I912, the Nebraska legislature in I9I3 passed an act to carry the amendment into effect. Section 8 of this act provided that initiative and referendum propositions should be printed or the blanket ballot "above and preceding

${ }^{169}$ Laughlin, A.Study in Constitutional Rigidity. I, Io Univ. Chi. L. Rev. 142, I47 (1943). 170 Ibid., at 153.

${ }_{17 x} \mathrm{Neb}$. L. (I9II) 223, §Id. This language was changed in $x 920$, but as far as the initiative is concerned the change appears to be of no significance. Neb. Comp. St. (r929) Art. 3, $\$ 4$.

172 Neb. L. (I9II) c. $223, \S$ Id.

${ }^{173}$ Information received from the Nebraska Secretary of State. Also, see Table in Rosewater, op. cit. supra note 158 , at 416 . 
all party names and circles." ${ }^{174}$ This section also repeated the language of the initiative and referendum constitutional amendment requiring the submission of initiative and referendum propositions in a nonpartisan manner and without indication of their approval by political parties or organizations.

In I9I 7 the Nebraska legislature submitted to the voters the question of calling a constitutional convention. ${ }^{775}$ It also decided to make use of the party-circle device, in order to prevent to a large extent nonvoters on the proposition from defeating it. Accordingly, the legislature amended the primary law of $I 97^{176}$ to provide that the proposition for calling a convention should be presented in the primary in the same manner and with the same results as was true with reference to constitutional amendments proposed by the legislature. ${ }^{77}$ The convention was called, and one of its amendments, which was adopted, changed the amending article of the Nebraska constitution. Thereafter, in order to adopt a legislatively proposed amendment, it was no longer necessary to secure for it a majority of the electors voting in a general election. Instead, it was provided: "If a majority of the electors voting on any such amendment adopt the same, it shall become a part of this constitution, provided the votes cast in favor of such amendment shall not be less than thirty-five per cent of the total votes cast at such election." It is a safe guess that the proviso clause was copied from the initiative and referendum provision. Another change was made, and it provided.that: "At such election said amendments shall be submitted to the electors for approval or rejection upon a ballot separate from that upon which the names of candidates appear."' ${ }^{778}$ This would appear to make it impossible to use the party-circle device on constitutional amendments, and it was not thereafter used in Nebraska. But Section 2 of Article XVI of the Nebraska Constitution which concerns the calling of a constitutional convention was not amended, and there appears to be no constitutional prohibition against the use of the party-circle for that limited purpose. For a time the statutes concerning elections seem confused; the Nebraska legislature was slow in repealing the old laws that provided for the party-circle device. ${ }^{x 9}$ The final step was the act of 1933 , which abolished the whole system of party-circle voting, even for candidates for

${ }_{174} \mathrm{Neb}$. L. (I9I3) I59, § 8. See, also, the form of the ballot and the card of instructions to voters in Neb. L: (I9I5) $3 \mathrm{I}$.

275 Neb. L. (IgI7) $24 \mathrm{I}$.

${ }_{176}$ Notes $163-67$ supra.

$x 77$ Neb. L. (IgI7) 36.

${ }_{178}$ Neb. Const. Art. $x 6, \S$ I.

${ }^{179}$ Neb. Comp. St. (I929) c. 32, $\S \S 503,504,517, x 138$. 
political offices. ${ }^{180} \mathrm{~A}$ wise state, Nebraska has been in this difficult situation. It found itself in a constitutional bog. It used the party-circle device to get out by adopting the initiative and referendum and then by changing its constitutional method of submitting and adopting legislatively proposed constitutional amendments. ${ }^{18 x}$ Once out of the bog, it finally abandoned the use of the party circle completely. There were no results to regret, no constitutional hangovers. Too bad that Tllinois has not been equally wise! It has been said that in the long run people obtain the type of government that they deserve.

Table 9 presents the figures of the voting on constitutional propositions in both the general elections and the primary elections in Nebraska.

Ohio-The history of constitutional proposals in Ohio from I85I to I902, inclusive, is similar to that of Illinois. The history of constitutional proposals in Ohio from I 902 to Igr2 reminds one of Nebraska. The constitution of Ohio of $185^{I}$ provided that: "All elections shall be by ballot." ${ }_{200}$ This simple statement, however, did not require that the ballot should be an official ballot prepared by a governmental agency. Accordingly, it did not prohibit party organizations from preparing the ballots to be used in elections. Likewise, it did not prohibit party organizations from printing their ballots in the form they pleased, so far as constitutional proposals were concerned. Thus, it was permissible for a party organization to print only the affirmative of a constitutional proposition, and so all persons using such a ballot would be voting for a constitutional proposal that appeared on the ballot, unless they used care to mark it otherwise. Likewise, a party organization could print the negative and ignore the affirma-

${ }^{180}$ Neb. Comp. St. Supp. (I94I) c. 32, $\$ \S 503,504$.

${ }^{18}$ The following quotation is from the Proceedings of the Constitutional Convention of Nebraska (xgrg-20) vol. I, pp. 667-668.

"Mr. Norton: I think this amendment to the Constitution is a very important one. At the present time it requires, as the chairman has stated, a majority vote at the election. As a result of that provision of the Constitution it has been necessary in the past, in order to secure the adoption of amendments submitted by the legislature, to resort to party endorsements, and count all straight party votes for the amendments; that has been the only way by which we have been able to make a majority voting on the question equal or exceed a majority at the election. I think one of the reasons the Committee had for providing for a separate ballot was to remove the party endorsement of Constitutional Amendments, and that is certainly desirable, because amending the Constitution by a straight party vote is not a desirable procedure, and I am certainly not in favor of this.

You will find one other change, and that is the thirty-five per cent provision which has been added and which makes this provision the same in that regard as the one which provides for initiating. The main importance of this proposal is that it will give the chance to adopt Constitutional Amendments by a majority voting on the question."

See for a brief general discussion, Procedure of Amending the Nebraska Constitution, 22 Neb. L. Rev. 39 (I943).

${ }^{200}$ Ohio Const. of $188_{5}$, art. $5, \S 2$, Ohio Code $(1853)$, p. $x_{5}$. 
TABLE $988 z$

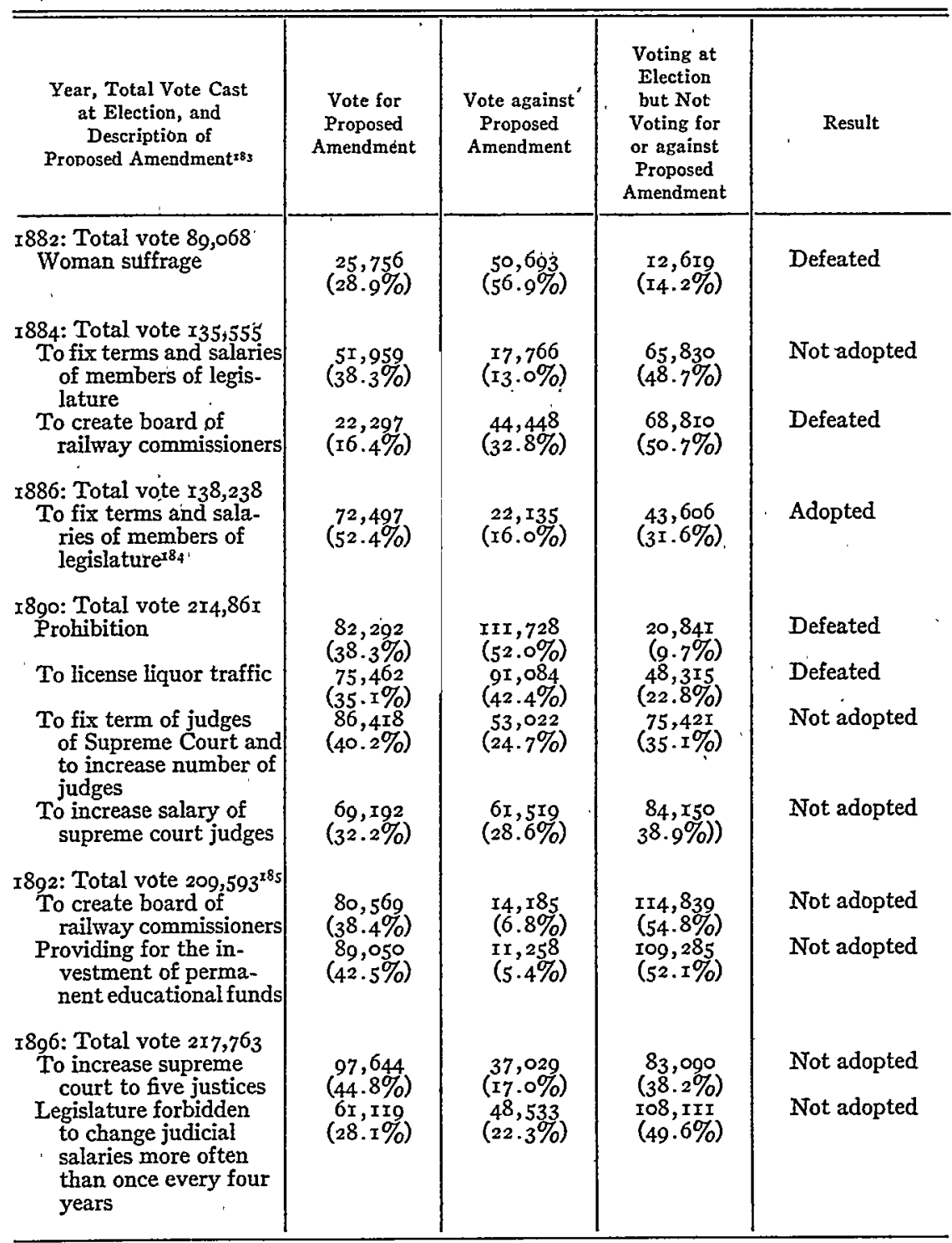

${ }_{182}$ Material in this table was taken from Nebraska Blue Book for r 942 , pp. 86-87; 4r2-r3, and from Rosewater, op. cit. supra note ${ }_{5} 8$.

${ }^{183}$ All amendments prior to IgI4 were proposed by the Nebraska legislature. In Igr2 an initiative and referendum amendment was adopted. Such of the amendments proposed after I I I2, as were proposed by initiative petitions, will be indicated by an asterisk. Except for the forty-one amendments submitted and adopted in 1920 , none was submitted by a constitutional convention.

${ }^{18} 4$ The figures stated at this place are the figures given on the legislative recount. The honesty of this recount vote has been challenged. See note 159 supra.

${ }^{185}$ The recount figures of the 1892 election are used. 
TABLE 9-Continued

\begin{tabular}{|c|c|c|c|c|}
\hline $\begin{array}{l}\text { Year, Total Vote Cast } \\
\text { at Election, and } \\
\text { Description of } \\
\text { Proposed Amendment }\end{array}$ & $\begin{array}{l}\text { Vote for } \\
\text { Proposed } \\
\text { Amendment }\end{array}$ & $\begin{array}{l}\text { Vote against } \\
\text { Proposed } \\
\text { Amendment }\end{array}$ & $\begin{array}{l}\text { Voting at } \\
\text { Election } \\
\text { but Not } \\
\text { Yoting for } \\
\text { or against } \\
\text { Proposed } \\
\text { Amendment }\end{array}$ & Result \\
\hline $\begin{array}{l}\text { 1896:-Contimued } \\
\text { Legislature forbidden } \\
\text { to change execu- } \\
\text { tive salaries more } \\
\text { often than once every } \\
\text { four years }\end{array}$ & $\begin{array}{c}59,496 \\
(27 \cdot 3 \%)\end{array}$ & $\begin{array}{c}47,6 \mathrm{rr} \\
(2 \mathrm{I} .9 \%)\end{array}$ & $\begin{array}{l}\text { rio, 656 } \\
(50.8 \%)\end{array}$ & Not adopted \\
\hline $\begin{array}{l}\text { Judicial power to be in } \\
\text { supreme court and } \\
\text { specified inferior } \\
\text { courts }\end{array}$ & $\begin{array}{c}60,094 \\
(27.6 \%)\end{array}$ & $\begin{array}{c}45,377 \\
(20.8 \%)\end{array}$ & $\begin{array}{l}\mathrm{Ir2}, 292 \\
(5 \mathrm{I} .6 \%)\end{array}$ & Not adopted \\
\hline $\begin{array}{l}\text { Legislature may increase } \\
\text { number of judges in } \\
\text { supreme and district } \\
\text { courts, but not oftener } \\
\text { than once in four years }\end{array}$ & $\begin{array}{c}59,343 \\
(27.3 \%)\end{array}$ & $\begin{array}{c}46,576 \\
(21.4 \%)\end{array}$ & $\begin{array}{l}\mathrm{III}, 844 \\
(5 \mathrm{I} .3 \%)\end{array}$ & Not adopted \\
\hline $\begin{array}{l}\text { To permit juries of less } \\
\text { than } 12 \text { and verdict } \\
\text { by vote of } 5 / 6 \text { of } \\
\text { jury }\end{array}$ & $\begin{array}{c}73,573 \\
(33.8 \%)\end{array}$ & $\begin{array}{c}39,006 \\
(\mathrm{I} 7.9 \%)\end{array}$ & $\begin{array}{l}\text { I05, 184 } \\
(48.3 \%)\end{array}$ & Not adopted \\
\hline $\begin{array}{l}\text { Fixing number of ex- } \\
\text { ecutive officers and } \\
\text { their terms of office }\end{array}$ & $\begin{array}{c}67,045 \\
(30.8 \%)\end{array}$ & $\begin{array}{c}40,597 \\
(18.6 \%)\end{array}$ & $\begin{array}{l}\text { Iro, I2I } \\
(50.6 \%)\end{array}$ & Not adopted \\
\hline $\begin{array}{l}\text { To establish the manner } \\
\text { of increasing number } \\
\text { of state officers }\end{array}$ & $\begin{array}{c}60,246 \\
(27.7 \%)\end{array}$ & $\begin{array}{c}44,063 \\
(20.2 \%)\end{array}$ & $\begin{array}{l}\text { II } 3,454 \\
(52.1 \%)\end{array}$ & Not adopted \\
\hline $\begin{array}{l}\text { Proposed amendment } \\
\text { relating to investment } \\
\text { of educational funds }\end{array}$ & $\begin{array}{c}78,447 \\
(36.0 \%)\end{array}$ & $\begin{array}{c}36,619 \\
(16.8 \%)\end{array}$ & $\begin{array}{l}\text { IO2,697 } \\
(47.2 \%)\end{array}$ & Not adopted \\
\hline $\begin{array}{l}\text { To permit merger of } \\
\text { city and county func- } \\
\text { tions in cities of } \\
\text { metropolitan class }\end{array}$ & $\begin{array}{c}56,960 \\
(26.2 \%)\end{array}$ & $\begin{array}{c}47,634 \\
(21.9 \%)\end{array}$ & $\begin{array}{l}\text { rr3, x69 } \\
(51.9 \%)\end{array}$ & Not adopted \\
\hline $\begin{array}{l}\text { Future elections to be } \\
\text { by ballot, or by such } \\
\text { other method as pro- } \\
\text { vided by law }\end{array}$ & $\begin{array}{c}62,303 \\
(28.6 \%)\end{array}$ & $\begin{array}{c}44,370 \\
(20.4 \%)\end{array}$ & $\begin{array}{l}\text { III, }, 090 \\
(51.0 \%)\end{array}$ & Not adopted \\
\hline $\begin{array}{l}\text { To permit submittal of } \\
\text { questions concerning } \\
\text { donations to works of } \\
\text { internal improvement } \\
\text { and manufacture to } \\
\text { voters }\end{array}$ & $\begin{array}{c}60,479 \\
(27.8 \%)\end{array}$ & $\begin{array}{l}45,669 \\
(21.0 \%)\end{array}$ & $\begin{array}{l}\mathrm{rrI}, 6 \mathrm{r} 5 \\
(5 \mathrm{I} .2 \%)\end{array}$ & Not adopted \\
\hline $\begin{array}{l}\text { I902: Total vote } 198,574 \\
\text { Change in method of } \\
\text { amending constitution }\end{array}$ & $\begin{array}{c}49,147 \\
(24.7 \%)\end{array}$ & $\begin{array}{l}15,999 \\
(8.1 \%)\end{array}$ & $\begin{array}{l}133,428 \\
(67.2 \%)\end{array}$ & Not adopted \\
\hline $\begin{array}{l}\text { I904: Total vote } 232,457 \\
\text { For calling constitu- } \\
\text { tional convention }\end{array}$ & $\begin{array}{c}32,820 \\
(14.1 \%)\end{array}$ & $\begin{array}{r}23,497 \\
\text { (10.1 } \%)\end{array}$ & $\begin{array}{l}176,140 \\
(75.8 \%)\end{array}$ & Not adopted \\
\hline $\begin{array}{l}\text { I906: Total vote } 194,692 \\
\text { To create a railway } \\
\text { commission }\end{array}$ & $\begin{array}{l}147,472 \\
(75 \cdot 7 \%)\end{array}$ & $\begin{array}{c}8,896 \\
(4.6 \%)\end{array}$ & $\begin{array}{l}38,324 \\
(19.7 \%)\end{array}$ & Adopted \\
\hline
\end{tabular}




\section{TABLE 9-Continued}

\begin{tabular}{|c|c|c|c|c|}
\hline $\begin{array}{l}\text { Year, Total Vote Cast } \\
\text { at Election, and } \\
\text { Description of } \\
\text { Proposed Amendment }\end{array}$ & $\begin{array}{l}\text { Vote for } \\
\text { Proposed } \\
\text { Amendment }\end{array}$ & $\begin{array}{l}\text { Vote against } \\
\text { Proposed } \\
\text { Amendment }\end{array}$ & $\begin{array}{l}\text { Voting at } \\
\text { Election } \\
\text { but Not } \\
\text { Voting for } \\
\text { or against } \\
\text { Proposed } \\
\text { Amendment }\end{array}$ & Result \\
\hline $\begin{array}{l}\text { 1908: Total vote } 27 \mathrm{~T}, 49 \mathrm{I} \\
\text { Change in number of } \\
\text { supreme court } \\
\text { justices }\end{array}$ & $\begin{array}{l}214,218 \\
(79.0 \%)\end{array}$ & $\begin{array}{l}16,271 \\
(6.0 \%)\end{array}$ & $\begin{array}{l}41,002 \\
(15.0 \%)\end{array}$ & Adopted \\
\hline $\begin{array}{l}\text { To prescribe method of } \\
\text { investing educational } \\
\text { funds }{ }^{187}\end{array}$ & $\begin{array}{l}213, \infty 00 \\
(78.5 \%)\end{array}$ & $\begin{array}{l}14,395 \\
(5.3 \%)\end{array}$ & $\begin{array}{l}44,096 \\
(16.2 \%)\end{array}$ & Adopted \\
\hline $\begin{array}{l}\text { 1910: Total vote } 243,390 \\
\text { To limit suffrage to } \\
\text { full citizens }\end{array}$ & $\begin{array}{l}100,450 \\
(4 \mathrm{I} .3 \%)\end{array}$ & $\begin{array}{l}74,878 \\
(30.7 \%)\end{array}$ & $\begin{array}{c}68,062 \\
(28.0 \%)\end{array}$ & Not adopted \\
\hline $\begin{array}{l}\text { I9 2: Total vote } 259, \text { I } 24 \\
\text { Initiative and referen- }\end{array}$ & 189,200 & I5,5I5 & 54,409 & Adopted \\
\hline $\begin{array}{l}\text { dum }{ }^{89} \\
\text { Term and salary of }\end{array}$ & $\begin{array}{l}(73.0 \%) \\
173,225\end{array}$ & $\begin{array}{l}(6.0 \%) \\
26,335\end{array}$ & $\begin{array}{l}(21.0 \%) \\
59,564\end{array}$ & Adopted \\
\hline $\begin{array}{l}\text { legislators } \\
\text { To create board of }\end{array}$ & $\begin{array}{l}(66.8 \%) \\
174,939\end{array}$ & $\begin{array}{l}\text { (10.2\%) } \\
25,439\end{array}$ & $\begin{array}{l}(23.0 \%) \\
58,746\end{array}$ & Adopted \\
\hline institutions $\mathrm{s}^{\mathrm{Igs}}$ of state & $(67.5 \%)$ & $(9.8 \%)$ & $(22.7 \%)$ & \\
\hline Biennial elections ${ }^{192}$ & $\begin{array}{l}\text { I 74, I5I } \\
(67.2 \%)\end{array}$ & $\begin{array}{l}25,048 \\
(9.7 \%)\end{array}$ & $\begin{array}{l}59,925 \\
(23.1 \%)\end{array}$ & Adopted \\
\hline $\begin{array}{l}\text { Home-rule charters for } \\
\text { cities of more than } \\
\text { five thousand }{ }^{993}\end{array}$ & $\begin{array}{l}\text { I } 64,579 \\
(63.5 \%)\end{array}$ & $\begin{array}{l}32,04 \mathrm{I} \\
(\mathrm{I} 2.4 \%)\end{array}$ & $\begin{array}{c}62,504 \\
(24.1 \%)\end{array}$ & Adopted \\
\hline $\begin{array}{l}\text { I9I4: Total vote } 246,94 \mathrm{I} \\
\text { Progressive income } \\
\text { tax }\end{array}$ & $\begin{array}{c}88,068 \\
(35.6 \%)\end{array}$ & $\begin{array}{c}82,136 \\
(33-3 \%)\end{array}$ & $\begin{array}{l}76,737 \\
(3 \mathrm{r} .1 \%)\end{array}$ & Not adopted \\
\hline
\end{tabular}

${ }^{186}$ Republican primary; Yes 26,153. No 7,824; Democratic primary, Yes $\mathrm{x} 2,716$. No 5,947.

${ }^{287}$ Republican primary, Yes 31,127. No 5,770; Democratic primary, Yes 15,513. No 4,335.

${ }^{188}$ Republican primary, Yes 11,779 . No 6,936; Democratic primary, Yes Io,062. No 11,524 .

${ }_{889}$ Republican primary, Yes 47,880 . No 7,754; Democratic primary, Yes 32,400 . No $4,4 \mathrm{II}$.

${ }_{190}$ Republican primary, Yes 37,724. No 12,832 ; Democratic primary, Yes 24,386 . No' 8,570 .

${ }_{19 x}$ Republican primary, Yes 38,168. No I0,791; Democratic primary, Yes 23,968 . No 7,683 .

${ }^{192}$ Republican primary, Yes 39,038 . No Ir,837; Democratic primary, Yes 26,118. No 7,273.

193 Republican primary, Yes 33,700 . No 15,007 ; Democratic primary, Yes 23,397. No 8,895. ${ }_{294}$ Republican primary, Yes 27,74 I. No 12,662 ; Democratic primary, Yes 24, 158. No I2,295. 
TABLE 9-Continued

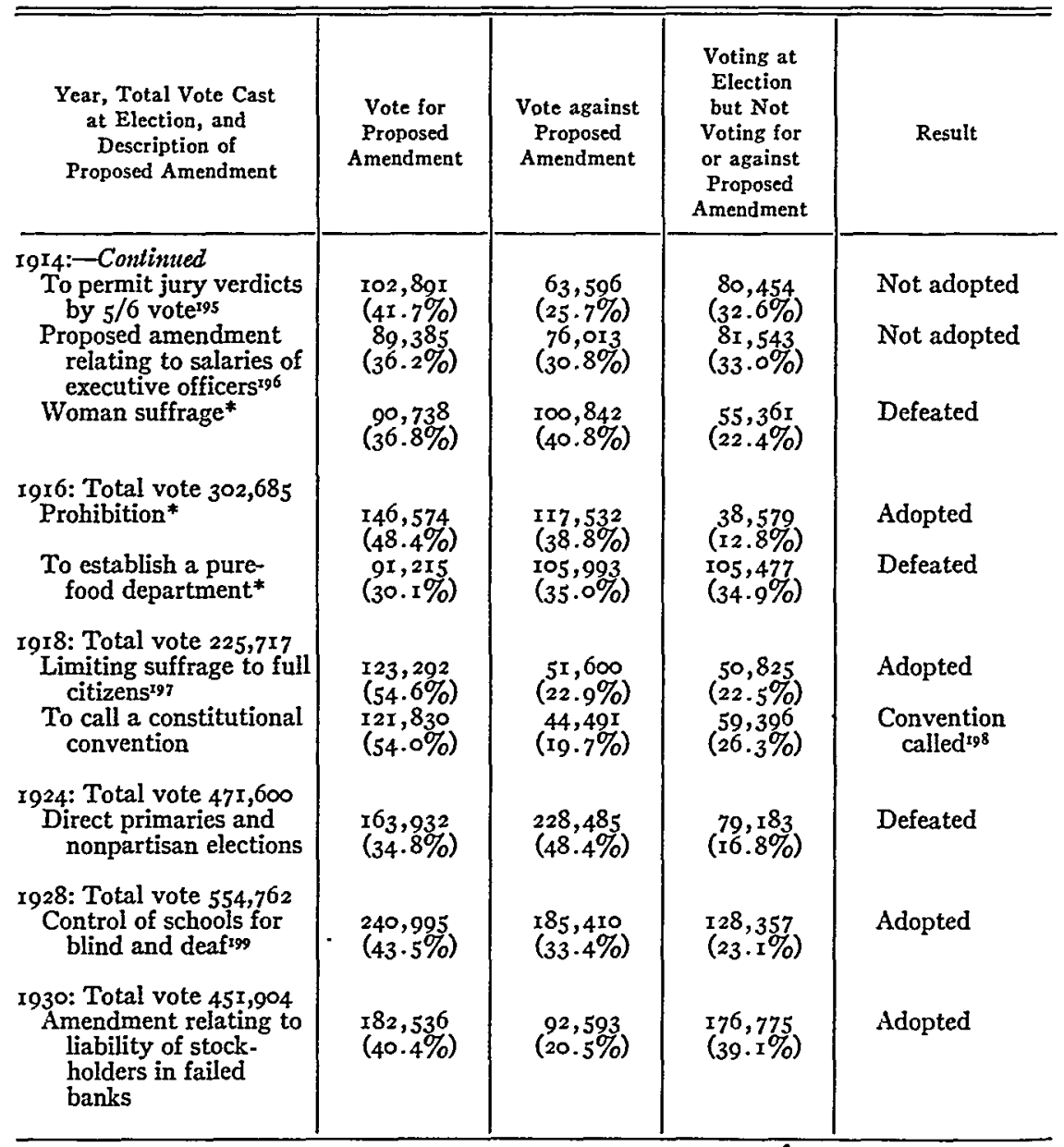

395 Republican primary, Yes 27,256. No r 2,986;

Democratic primary, Yes 24,04I. No I2,I52.

${ }^{196}$ Republican primary, Yes 23,020 . No 14,$545 ;$

Democratic primary, Yes 20,219. No I3,949.

${ }_{97}$ Rosewater, op. cit. supra note (158), does not present the primary vote on this amendment; but there is no reason to believe that it was not approved in the primary voting. The primary vote on the convention proposal was:

Republican primary, Yes 27,353 . No 18,635 ;

Democratic primary, Yes 23,033 . No 18,982 .

${ }^{98}$ The convention met and proposed forty-one amendments, all of which were approved by popular vote in 1920. Nebraska Blue Book 83 (1942).

${ }^{299}$ This election was declared void by the Supreme Court. State v. Cline, II8 Neb. I5O, 224 N.W. 6 (1929). 
TABLE 9-Continued

\begin{tabular}{|c|c|c|c|c|}
\hline $\begin{array}{l}\text { Year, Total Vote Cast } \\
\text { at Election, and } \\
\text { Description of } \\
\text { Proposed Amendment }\end{array}$ & $\begin{array}{l}\text { Vote for } \\
\text { Proposed } \\
\text { Amendment }\end{array}$ & $\begin{array}{l}\text { Vote against } \\
\text { Proposed } \\
\text { Amendment }\end{array}$ & $\begin{array}{l}\text { Voting at } \\
\text { Election } \\
\text { but Not } \\
\text { Voting for } \\
\text { or against } \\
\text { Proposed } \\
\text { Amendment }\end{array}$ & Result \\
\hline $\begin{array}{l}\text { 1930:-Continued } \\
\text { Increasing state debt } \\
\text { limitation }\end{array}$ & $\begin{array}{l}120,554 \\
(26.7 \%)\end{array}$ & $\begin{array}{l}\mathrm{r} 44,882 \\
(32.0 \%)\end{array}$ & $\begin{array}{l}\mathrm{x} 86,468 \\
(4 \mathrm{I} \cdot 3 \%)\end{array}$ & Defeated \\
\hline $\begin{array}{l}\text { I934: Total vote } 578,764 \\
\text { Repeal of Pro- } \\
\text { hibition } \\
\text { Unicameral legis- } \\
\text { lature* } \\
\text { Pari-mutuel betting* }\end{array}$ & $\begin{array}{l}328,074 \\
(56.7 \%) \\
286,086 \\
(49.4 \%) \\
251,111 \\
(43.4 \%)\end{array}$ & $\begin{array}{l}218,107 \\
(37.7 \%) \\
193,152 \\
(33.4 \%) \\
187,455 \\
(32.4 \%)\end{array}$ & $\begin{array}{c}32,583 \\
(5.6 \%) \\
99,526 \\
(17.2 \%) \\
140,198 \\
(24.2 \%)\end{array}$ & $\begin{array}{l}\text { Adopted } \\
\text { Adopted } \\
\text { Adopted }\end{array}$ \\
\hline $\begin{array}{l}\text { 1936: Total vote } 6 \times 7,066 \\
\text { To abolish office of } \\
\text { land commissioner } \\
\text { Proposed amendment } \\
\text { relating to liability of } \\
\text { stockholders in failed } \\
\text { banks }\end{array}$ & $\begin{array}{l}246,682 \\
(40.0 \%) \\
204,9 \% 4 \\
(33.2 \%)\end{array}$ & $\begin{array}{l}210,143 \\
(34.0 \%) \\
234,908 \\
(38.1 \%)\end{array}$ & $\begin{array}{l}160,24 \mathrm{I} \\
(26.0 \%) \\
177,254 \\
(28.7 \%)\end{array}$ & $\begin{array}{l}\text { Adopted } \\
\text { Defeated }\end{array}$ \\
\hline $\begin{array}{l}\text { I938: Total vote } 5 \circ 7,47 \mathrm{I} \\
\text { To license slot } \\
\text { machines* } \\
\text { Proposed amendment } \\
\text { relating to liability of } \\
\text { stockholders in closed } \\
\text { banks }\end{array}$ & $\begin{array}{l}115,189 \\
(22.7 \%) \\
190,328 \\
(37.5 \%)\end{array}$ & $\begin{array}{l}333,120 \\
(65.6 \%) \\
178,998 \\
(35.3 \%)\end{array}$ & $\begin{array}{l}59,162 \\
(11.7 \%) \\
\text { r } 38,145 \\
(27.2 \%)\end{array}$ & $\begin{array}{l}\text { Defeated } \\
\text { Adopted }\end{array}$ \\
\hline $\begin{array}{l}\text { To reduce number of } \\
\text { elective executive } \\
\text { officers }\end{array}$ & $\begin{array}{c}89,357 \\
(17.6 \%)\end{array}$ & $\begin{array}{l}233,319 \\
(46.0 \%)\end{array}$ & $\begin{array}{l}I 84,795 \\
(36.4 \%)\end{array}$ & Defeated \\
\hline $\begin{array}{l}\text { To make state superin- } \\
\text { tendent of public in- } \\
\text { struction a member of } \\
\text { the board of educa- } \\
\text { tional lands and funds }\end{array}$ & $\begin{array}{l}145,345 \\
(28.6 \%)\end{array}$ & $\begin{array}{l}I 68,035 \\
(33.1 \%)\end{array}$ & $\begin{array}{l}\text { I94,ogr } \\
(38.3 \%)\end{array}$ & Defeated \\
\hline $\begin{array}{l}\text { To change number of } \\
\text { members of board of } \\
\text { pardons }\end{array}$ & $\begin{array}{l}\operatorname{IxI}, 284 \\
(2 \mathrm{x} .9 \%)\end{array}$ & $\begin{array}{l}189,056 \\
(37-3 \%)\end{array}$ & $\begin{array}{l}207,13 \mathrm{I} \\
(40.8 \%)\end{array}$ & Defeated \\
\hline $\begin{array}{l}\text { To establish recall of } \\
\text { elective executive } \\
\text { officers of the state }\end{array}$ & $\begin{array}{l}\mathrm{I} 24,829 \\
(24.6 \%)\end{array}$ & $\begin{array}{l}\text { I7o,883 } \\
(33 \cdot 7 \%)\end{array}$ & $\begin{array}{l}211,759 \\
(41.7 \%)\end{array}$ & Defeated \\
\hline $\begin{array}{l}\text { 1940: Total vote } 623,78 \mathrm{I} \\
\text { State superintendent of } \\
\text { public instruction } \\
\text { member of board of } \\
\text { educational lands and } \\
\text { funds }\end{array}$ & $\begin{array}{l}239,805 \\
(38.4 \%)\end{array}$ & $\begin{array}{l}\mathrm{I} 79,600 \\
(28.8 \%)\end{array}$ & $\begin{array}{l}204,376 \\
(32.8 \%)\end{array}$ & Adopted \\
\hline $\begin{array}{l}\text { Optional form of county } \\
\text { government }\end{array}$ & $\begin{array}{l}173,107 \\
(27.8 \%)\end{array}$ & $\begin{array}{l}254,639 \\
(40.8 \%)\end{array}$ & $\begin{array}{l}\mathrm{Ig} 6,035 \\
(3 \mathrm{r} \cdot 4 \%)\end{array}$ & Defeated \\
\hline $\begin{array}{l}\text { I942: Total vote } 387,992 \\
\text { County home rule }\end{array}$ & $\begin{array}{l}\mathrm{I} 25,513 \\
(32.4 \%)\end{array}$ & $\begin{array}{l}I 60,80 \mathrm{I} \\
(4 \mathrm{I} .4 \%)\end{array}$ & $\begin{array}{l}\text { IOI }, 678 \\
(26.2 \%)\end{array}$ & Defeated \\
\hline
\end{tabular}


tive. Also, there apparently was nothing to prevent a party organization from printing both the affirmative and the negative of the proposition, thus taking no position on the constitutional proposal. Furthermore, there was nothing to require a party organization or any group or person who prepared a ballot from entirely omitting a constitutional proposal from that ballot:

Information has been obtained as to the practice of the political parties in preparing their ballots in Ohio prior to $189 \mathrm{r}$. In the Ohio constitutional convention of I9I2 Mr. Starbuck' Smith of Hamilton County made this statement: "The old custom, as you will remember, from I85I to I89r, was for the political party machine to print a separate ballot and, if it saw fit, to print the constitutional amendment right on the ballot with the party ticket. The parties did this so that a man going in to cast his vote would vote for the constitutional amendment that his political party desired." ${ }^{20 x}$

The importance of this method of preparing ballots on constitutional proposals in Ohio becomes manifest when one considers the amending article, i.e., Article XVI of the Ohio Constitution of $x 8_{5}$ r. This article provided for legislatively proposed constitutional amendments, for the calling of a constitutional convention upon a resolution of the General Assembly, and for the automatic submission of the question of calling a constitutional convention every twenty years. Section I of Article XVI concerning constitutional amendments provided that ". . . if a majority of the electors, voting at such election, shall adopt such amendments, the same shall become a part of the constitution." "Such election" was a general election, viz., "the next election for Senators and Representatives." 202 Sections 2 and 3 contain similar requirements. This language of Section I was construed to mean that an amendment failed of adoption, even though it received more affirmative than negative votes, when it failed to receive a majority of the total number of electors voting in the general election..$^{203}$ This provision, therefore, is the same restrictive provision that appears in the Illinois constitution and the constitutions of the five other states which are being considered. ${ }^{204}$

During the period of forty years from $185 \mathrm{I}$ to $\mathrm{I} 8 \mathrm{~g} \mathrm{I}$, twenty-five consti-

${ }^{20 x} 2$ Proceedings and Debates of the Const. Convention of Ohio I366 (IgI2). Mr. Smith also stated: "We have adopted some constitutional amendments in Ohio, but they have been adopted because the political parties wanted them."

${ }^{202}$ Ohio Code (1853), p. 26.

${ }^{203}$ State v. Foraker, 46 Ohio St. 677,23 N.E. 49 ( (I 889 ). The proposed amendment considered in that case was the one submitted in 1889 to provide for biennial elections. See Table Io.

${ }^{204}$ See ro Univ. Chi. L. Rev. 142 (1943). 
tutional proposals were submitted to the voters of Ohio. Seven were adopted, but twelve were not adopted, even though they received a favorable majority of those voting on the propositions. Six of the propositions were defeated. Table to presents the figures. It will be observed that four of the seven proposals adopted, were adopted in the election of 1885 .

It is interesting to observe that on the amendment submitted in 1867 all but 2.5 per cent of the voters expressed themselves on the amendment. Also observe that in $187 \mathrm{I}$ and in 1885 more than 80 per cent of the voters expressed themselves on the constitutional propositions except one. Such heavy voting would indicate that party organizations had taken a position on the propositions and had printed this on the ballots which they had prepared.

But it is unnecessary to speculate. Galbreath in his comprehensive History of Ohio has explained the method by which all six amendments were adopted before $18 \mathrm{gr}$. Concerning the supreme court commission amendment adopted in 1875 he states:207 "The two leading political parties united in an effort to pass this amendment. Practically all the newspapers of the state favored it and the speakers of both parties, in the stirring campaign of 1875 , paused long enough in their partisan appeals to urge all voters to support it."

Relative to the adoption of the judiciary amendment in 1883 , Galbreath gives a more detailed explanation: ${ }^{208}$

The amendment was but little-discussed in the campaign of 1883 . Popular interests centered in two other amendments, relating to the prohibition and regulation of the liquor traffic, and yet the amendment relating to the judiciary carried easily, while those relating to the liquor traffic failed.

The following extract from an editorial in the Ohio State Journal explains why the judiciary amendment had such "plain sailing":

"The constitutional amendment proposing a change in the state judiciary has had pretty plain sailing thus far, and arrangements having been made whereby 'Judicial amendment, Yes' appears on the ticket of both parties, it will doubtless be adopted. The State Bar Association, after a discussion of the proposed measure, decided to adopt it and advocate it, and lawyers generally have pronounced in favor of it, as far as they have taken any position at all in regard to it."

This reveals the plan to catch the indifferent and uninformed voter at an election before the present modified Australian system was adopted. Instead of writing on the ballot

Judicial amendment, Yes

Judicial amendment, No

207 i Galbreath, History of Ohio 9I (I925).

${ }^{208}$ Ibid., at 91-92. 
TABLE $10^{205}$

\begin{tabular}{|c|c|c|c|c|}
\hline $\begin{array}{l}\text { Year, Total Vote Cast } \\
\text { at Election, and } \\
\text { Description of } \\
\text { Proposed Amendment }\end{array}$ & $\begin{array}{l}\text { Vote for } \\
\text { Proposed } \\
\text { Amendment }\end{array}$ & $\begin{array}{l}\text { Vote against } \\
\text { Proposed } \\
\text { Amendment }\end{array}$ & $\begin{array}{l}\text { Voting at } \\
\text { Election } \\
\text { but Not } \\
\text { Voting for } \\
\text { or against } \\
\text { Proposed } \\
\text { Amendment }\end{array}$ & Result \\
\hline $\begin{array}{l}\text { I857: Total vote }{ }^{206} 332,126 \\
\text { Annual sessions of }\end{array}$ & $15 \mathrm{I}, 202$ & 31,890 & & Not adopted \\
\hline $\begin{array}{l}\text { General Assembly } \\
\text { To give General As- } \\
\text { sembly more control } \\
\text { over corporations }\end{array}$ & $\begin{array}{l}(45 \cdot 5 \%) \\
123,229 \\
(37 . x \%)\end{array}$ & $\begin{array}{c}(9.6 \%) \\
35,973 \\
(10.8 \%)\end{array}$ & $\begin{array}{l}(44.9 \%) \\
172,924 \\
(52.1 \%)\end{array}$ & Not adopted \\
\hline $\begin{array}{l}\text { Equality of individual } \\
\text { and bank taxation }\end{array}$ & $\begin{array}{l}160,470 \\
(48.3 \%)\end{array}$ & $\begin{array}{l}20,609 \\
(6.2 \%)\end{array}$ & $\begin{array}{l}\text { I5I, 047 } \\
(45.5 \%)\end{array}$ & Not adopted \\
\hline $\begin{array}{l}\text { Single legislative dis- } \\
\text { tricts }\end{array}$ & $\begin{array}{l}147,260 \\
(44.3 \%)\end{array}$ & $\begin{array}{l}32,657 \\
(9.8 \%)\end{array}$ & $\begin{array}{l}152,209 \\
(45.0 \%)\end{array}$ & Not adopted \\
\hline $\begin{array}{l}\text { Proposed amendment } \\
\text { changing district } \\
\text { court }\end{array}$ & $\begin{array}{l}156,646 \\
(47.2 \%)\end{array}$ & $\begin{array}{l}30,039 \\
(9.0 \%)\end{array}$ & $\begin{array}{l}\mathrm{r} 45,44 \mathrm{I} \\
(43.8 \%)\end{array}$ & Not adopted \\
\hline $\begin{array}{l}\text { 1859: Total vote } 355,794 \\
\text { Annual sessions of } \\
\text { General Assembly }\end{array}$ & $\begin{array}{l}\text { Ior }, \text { I } 78 \\
(28.4 \%)\end{array}$ & $\begin{array}{l}75,394 \\
(21.2 \%)\end{array}$ & $\begin{array}{l}179,222 \\
(50.4 \%)\end{array}$ & Not adopted \\
\hline 1867: Total vote 484,227 & & & & \\
\hline Suffrage restrictions & $\begin{array}{l}216,987 \\
(44.8 \%)\end{array}$ & $\begin{array}{l}255,340 \\
(52.7 \%)\end{array}$ & $\begin{array}{l}\mathrm{II}, 900 \\
(2.5 \%)\end{array}$ & Defeated \\
\hline I871: Total vote 459,990 & & & & \\
\hline $\begin{array}{l}\text { Proposed constitutional } \\
\text { convention }\end{array}$ & $\begin{array}{l}267,618 \\
(58.2 \%)\end{array}$ & $\begin{array}{l}\text { I04, 23I } \\
(22.6 \%)\end{array}$ & $\begin{array}{c}88, I_{4} I \\
\left(x_{9} .2 \%\right)\end{array}$ & Adopted \\
\hline 1875: Total vote 595,248 & & & & \\
\hline Dog tax & $\begin{array}{l}278,005 \\
(46.7 \%)\end{array}$ & $\begin{array}{l}73,80 \mathrm{r} \\
(\mathrm{I} 2.4 \%)\end{array}$ & $\begin{array}{l}243,442 \\
(40.9 \%)\end{array}$ & Not adopted \\
\hline $\begin{array}{l}\text { Supreme court com- } \\
\text { mission }\end{array}$ & $\begin{array}{l}339,076 \\
(57.0 \%)\end{array}$ & $\begin{array}{l}98,561 \\
(16.6 \%)\end{array}$ & $\begin{array}{l}\text { I57,6I1 } \\
(26.4 \%)\end{array}$ & Adopted \\
\hline 1877: Total vote $5,57,503$ & & & & \\
\hline Judiciary amendment & $\begin{array}{l}54,896 \\
(9.8 \%)\end{array}$ & $\begin{array}{l}268,478 \\
(48.2 \%)\end{array}$ & $\begin{array}{l}234,129 \\
(42.0 \%)\end{array}$ & Defeated \\
\hline $\begin{array}{l}\text { 1879: Total vote } 670,7 \mathrm{II} \\
\text { Change of time of } \\
\text { election of members } \\
\text { of General Assembly }\end{array}$ & $\begin{array}{l}166,285 \\
(24.8 \%)\end{array}$ & $\begin{array}{l}r 58,642 \\
(23.6 \%)\end{array}$ & $\begin{array}{l}345,784 \\
(5 \times .6 \%)\end{array}$ & Not adopted \\
\hline
\end{tabular}

${ }^{205}$ This table and Tables $\mathrm{I}_{1}, \mathrm{I}_{2}, \mathrm{I}_{3}$, and $\mathrm{I}_{4}$ were compiled from information in Patterson, The Constitutions of Ohio and Allied Documents $161-299$ (I9I2). Many of the votes are also recorded in Galbreath, op. cit. infra note 207 , at 68-94. There are discrepancies in the two reports, but for our purposes they are not material. Valuable assistance was rendered by Professor Paul Kelso of Ohio State University.

${ }^{206} \mathrm{All}$ elections referred to in these tables were general elections. The constitution of 1851 specified that constitutional amendments should be submitted to popular vote at the elections of members of the state legislature. Such elections occurred in odd-numbered years until after an amendment adopted in 1905 . 
TABLE 10-Continued

\begin{tabular}{|c|c|c|c|c|}
\hline $\begin{array}{l}\text { Year, Total Vote Cast } \\
\text { at Election, and } \\
\text { Description of } \\
\text { Proposed Amendment }\end{array}$ & $\begin{array}{l}\text { Vote for } \\
\text { Proposed } \\
\text { Amendment }\end{array}$ & $\begin{array}{l}\text { Vote against } \\
\text { Proposed } \\
\text { Amendment }\end{array}$ & $\begin{array}{l}\text { Voting at } \\
\text { Election } \\
\text { but Not } \\
\text { Voting for } \\
\text { or against } \\
\text { Proposed } \\
\text { Amendment }\end{array}$ & Result \\
\hline $\begin{array}{l}\text { r879:-Contimied } \\
\text { Change of time of } \\
\text { election of state } \\
\text { officials }\end{array}$ & $\begin{array}{l}. \mathrm{I} 62,728 \\
(24.3 \%)\end{array}$ & $\begin{array}{l}x 55,257 \\
(23.1 \%)\end{array}$ & $\begin{array}{l}352,726 \\
(52.6 \%)\end{array}$ & Not adopted \\
\hline $\begin{array}{l}\text { Change of time of } \\
\text { election of township } \\
\text { trustees }\end{array}$ & $\begin{array}{l}\text { I97,223 } \\
(29.4 \%)\end{array}$ & $\begin{array}{l}\mathrm{r} 30,455 \\
\text { (r9.5\%) }\end{array}$ & $\begin{array}{l}343,033 \\
(51.1 \%)\end{array}$ & Not adopted \\
\hline Judiciary amendment & $\begin{array}{l}I 59,630 \\
(23.8 \%)\end{array}$ & $\begin{array}{l}\text { I63,639 } \\
(24.4 \%)\end{array}$ & $\begin{array}{l}347,442 \\
(51.8 \%)\end{array}$ & Defeated \\
\hline $\begin{array}{l}\text { I883: Total vote } 72 \mathrm{I}, 3 \mathrm{xo} \\
\text { Regulation and taxation }\end{array}$ & 99,238 & 288,605 & 333,467 & Defeated \\
\hline $\begin{array}{l}\text { of liquor traffic } \\
\text { Prohibition of liquor }\end{array}$ & $\begin{array}{l}(13.8 \%) \\
323,129\end{array}$ & $\begin{array}{l}(40.0 \%) \\
226,595\end{array}$ & & Not adopted \\
\hline $\begin{array}{l}\text { traffic } \\
\text { Judiciary amendment }\end{array}$ & $\begin{array}{l}(44.8 \%) \\
400,919 \\
(55.6 \%)\end{array}$ & $\begin{array}{l}(3 r .4 \%) \\
144,335 \\
(20.0 \%)\end{array}$ & $\begin{array}{l}(23.8 \%) \\
176,056 \\
(24.4 \%)\end{array}$ & Adopted \\
\hline $\begin{array}{l}\text { 1885: Total vote } 733,967 \\
\text { To change fall elections } \\
\text { of members of } \\
\text { General Assembly to } \\
\text { November }\end{array}$ & $\begin{array}{l}538,858 \\
(73.4 \%)\end{array}$ & $\begin{array}{l}53,177 \\
(7.3 \%)\end{array}$ & $\begin{array}{l}\text { I4I,932 } \\
(\mathrm{I} 9.3 \%)\end{array}$ & Adopted \\
\hline $\begin{array}{l}\text { To change fall elections } \\
\text { of state officials to } \\
\text { November }\end{array}$ & $\begin{array}{l}536,273 \\
(73.1 \%)\end{array}$ & $\begin{array}{l}53,223 \\
(7.2 \%)\end{array}$ & $\begin{array}{l}I_{44}, 47 \mathrm{r} \\
\left(\mathrm{I}_{9.7 \%}\right)\end{array}$ & Adopted \\
\hline $\begin{array}{l}\text { To change fall elections } \\
\text { of county officials to } \\
\text { November }\end{array}$ & $\begin{array}{l}534,660 \\
(72.8 \%)\end{array}$ & $\begin{array}{l}53,629 \\
(7 \cdot 3 \%)\end{array}$ & $\begin{array}{l}\text { I } 45,678 \\
\text { (I9.9\%) }\end{array}$ & Adopted \\
\hline $\begin{array}{l}\text { Election and term of } \\
\text { township officials }\end{array}$ & $\begin{array}{l}469, \pm 13 \\
(63.9 \%)\end{array}$ & $\begin{array}{l}59,929 \\
(8.2 \%)\end{array}$ & $\begin{array}{l}204,925 \\
(27.9 \%)\end{array}$ & Adopted \\
\hline $\begin{array}{l}\text { I88g: Total vote } 780,304 \\
\text { Giving General Assem- } \\
\text { bly power over tax- } \\
\text { ation }\end{array}$ & $\begin{array}{l}245,438 \\
(3 \mathrm{x} .5 \%)\end{array}$ & $\begin{array}{l}273,268 \\
(35.0 \%)\end{array}$ & $\begin{array}{l}26 x, 598 \\
(33 \cdot 5 \%)\end{array}$ & Defeated \\
\hline $\begin{array}{l}\text { Proposed single legis- } \\
\text { lative district }\end{array}$ & $\begin{array}{l}245,444 \\
(3 \mathrm{I} .4 \%)\end{array}$ & $\begin{array}{l}259,420 \\
(33 \cdot 3 \%)\end{array}$ & $\begin{array}{l}275,440 \\
(35.3 \%)\end{array}$ & Defeated \\
\hline Biennial elections & $\begin{array}{l}257,662 \\
(33.0 \%)\end{array}$ & $\begin{array}{l}254,215 \\
(32.6 \%)\end{array}$ & $\begin{array}{l}268,427 \\
(34.4 \%)\end{array}$ & Not adopted \\
\hline
\end{tabular}

and permitting the voter to express his preference by striking out one of the two, by mutual arrangement the political parties placed on each ballot

Judicial amendment, Yes.

This arrangement was denounced by Judge Rufus R. Ranney in a letter to the Cleveland Leader. After an argument against the amendment on its merits, Judge Ranney stated: ". . . . But leaving all this aside, I certainly should not have felt myself called upon to more than deposit my vote against the scheme, if an equal opportunity 
were afforded those who favor or oppose it to express their wishes at the ballot box in accordance with the legislative resolution submitting it, which expressly requires the affirmative or negative to be placed upon the ballot as the elector may desire to vote.

"I am now, however, informed (whether correctly or not I can not say) that an understanding between the committees of the several political parties exists, by which affirmation only is to be printed upon the ballots to be used at the election. If such a conspiracy really exists and is attempted to be carried out, I have no hesitation in declaring it a base fraud and imposition upon the electors and an attempt to change the constitution by a species of juggling without the free consent of the majority of them....."

The revelation of the clever arrangement of the political leaders did not affect the result of the election, and the judicial amendment easily prevailed, the vote standing:

Total 731,310 Necessary 365,656 For 400,9I9 Against 144,335

Four amendments were adopted in 1885 . Concerning at least three of them and probably all of them, Galbreath makes this comment:209 "They were all submitted in the same manner as the judiciary amendment of I883, and by mutual agreement of political parties only the affirmative votes were printed on the ballots."

In I89I, Ohio adopted a revised Australian ballot law. Section I 4 of this law provided: "Whenever the approval of a constitutional amendment or other question is to be submitted to a vote of the people, such question shall be printed on the ballot after the list of candidates." 2 ro Thus, Ohio attempted to solve the problem of submitting constitutional proposals in the same way that Illinois attempted to solve it in the same year. ${ }^{2 x x}$ This attempt proved to be a failure in both states. In the elections of $189 \mathrm{I}$ and I893 four proposed constitutional propositions were submitted. As shown by Table II, one for a convention was defeated. The three amendments were not adopted even though they received approximately four times as many affirmative votes as negative. These were the only two elections on constitutional proposals in Ohio after the adoption of the revised Australian ballot law until Igo3.

On May 2, I902, the Ohio General Assembly passed an act which came to be known as the Longworth Act. This law in truth was a party-circle law, and was similar to the law enacted in Nebraska in IgoI. The first three sections of the Ohio law provided:2r2

209 Ibid., at 93. 2ro Ohio L. (I89I), p. 458. 21x Op. cit. supra note 204, at I52.

${ }^{212}$ Ohio L. (IgO2), P. 352. The validity of this act was challenged, but the Ohio Supreme Court held it constitutional, State v. Laylin, 69 Ohio St. x, 68 N.E. 574 (I903) ("It was not the design or intention of the constitution to put a premium on ignorance or indifferentism [sic] at the same time that it is the duty of every citizen to inform himself and to vote upon everymatter submitted to a vote of the people"). 
Section $x$. That whenever the approval of any constitutional amendment is to be submitted to a vote of the people, any state convention of a political party, which at the last preceding general election polled at least one per cent. of the entire vote cast in the state, may take action in favor of, or against the adoption of such constitutional amendment to be submitted at the next succeeding annual election, and shall certify such action to the secretary of state in the manner provided for certifying nominations for state offices, whereupon said action upon such constitutional amendment shall be printed upon the regular ballot at said election as a part of the party ticket of said party in the manner hereinafter provided.

Section 2. Such constitutional amendment or amendments shall be stated in words sufficient to clearly designate the same, and. such statement or statements shall be printed in a separate column on the regular ballot. On the line below such statement

TABLE 11

\begin{tabular}{|c|c|c|c|c|}
\hline $\begin{array}{l}\text { Year, Total Vote Cast } \\
\text { at Election, and } \\
\text { Description of } \\
\text { Proposed Amendment }\end{array}$ & $\begin{array}{l}\text { Vote for } \\
\text { Proposed } \\
\text { Amendment }\end{array}$ & $\begin{array}{l}\text { Vote against } \\
\text { Proposed } \\
\text { Amendment }\end{array}$ & $\begin{array}{l}\text { Voting at } \\
\text { Election } \\
\text { but Not } \\
\text { Voting for } \\
\text { or against } \\
\text { Proposed } \\
\text { Amendment }\end{array}$ & Result \\
\hline $\begin{array}{l}\text { 189r: Total vote } 803,328 \\
\text { Proposed constitutional } \\
\text { convention } \\
\text { Taxation }\end{array}$ & $\begin{array}{l}99,789 \\
(12.4 \%) \\
303,177 \\
(37.7 \%)\end{array}$ & $\begin{array}{l}\mathrm{r} 61,722 \\
(20.1 \%) \\
65,014 \\
(8.1 \%)\end{array}$ & $\begin{array}{l}54 \mathrm{x}, 8 \mathrm{r} \\
(67.5 \%) \\
435, \mathrm{x} 37 \\
(54.2 \%)\end{array}$ & $\begin{array}{l}\text { Defeated } \\
\text { Not adopted }\end{array}$ \\
\hline $\begin{array}{l}\text { I893: Total vote } 835,604 \\
\text { Proposed single legis- } \\
\text { lative district } \\
\text { Tax on franchises and } \\
\text { privileges }\end{array}$ & $\begin{array}{l}322,887 \\
(38.6 \%) \\
322,422 \\
(38.6 \%)\end{array}$ & $\begin{array}{l}8 \mathrm{I}, 48 \mathrm{r} \\
(9.8 \%) \\
82,28 \mathrm{I} \\
(9.8 \%)\end{array}$ & $\begin{array}{l}431,236 \\
(51.6 \%) \\
430,901 \\
(51.6 \%)\end{array}$ & $\begin{array}{l}\text { Not adopted } \\
\text { Not adopted }\end{array}$ \\
\hline
\end{tabular}

shall be printed the word "Yes," and on the next line below shall be printed the word "No"; provided that said statement shall also be placed on the official ballot immediately below the names of the candidates for state offices on the regular ticket of any party or parties certifying action thereon as provided in section I of this act, being followed by the word "yes" or the word "no" accordingly as affirmative or negative action shall have been certified thereon by said party or parties, and said statement of said amendment or question, with the action taken thereon by said party, shall thereupon become a part of said party ticket.

Section 3. The elector shall observe the following rules in [marking] making his ballot:

I. He may make a cross mark in the blank space to the left of and before the answer he desires to give to the submission of any constitutional amendment, in the separate column devoted to said amendment, or he may make a cross mark in the blank space to the left of and before the statement, and answer thereto, of any constitutional amendment, as the same may be printed and certified on the ticket of any political party; whereupon, such mark shall cast his ballot for the answer opposite which it is made. 
2. The voter may make a cross mark in the blank circular space at the head of any ticket upon which is printed the statement of any constitutional amendment or question, and the certified answer thereto, which mark shall cast his ballot for the certified answer to the submission of each and every constitutional amendment so printed on said ticket, unless he shall have specifically answered any of said constitutional amendments otherwise elsewhere on the ballot in the manner heretofore stated.

TABLE 12

\begin{tabular}{|c|c|c|c|c|}
\hline $\begin{array}{l}\text { Year, Total Vote Cast } \\
\text { at Election, and } \\
\text { Description of } \\
\text { Proposed Amendment }\end{array}$ & $\begin{array}{l}\text { Vote for } \\
\text { Proposed } \\
\text { Amendment }\end{array}$ & $\begin{array}{l}\text { Vote against } \\
\text { Proposed } \\
\text { Amendment }\end{array}$ & $\begin{array}{l}\text { Voting at } \\
\text { Election } \\
\text { but Not } \\
\text { Voting for } \\
\text { or against } \\
\text { Proposed } \\
\text { Amendment }\end{array}$ & Result \\
\hline $\begin{array}{l}\text { 1903: Total vote } 877,203 \\
\text { Amendment giving each } \\
\text { county at least one } \\
\text { representative }\end{array}$ & $\begin{array}{l}757,505 \\
(86.4 \%)\end{array}$ & $\begin{array}{l}26,497 \\
(3.0 \%)\end{array}$ & $\begin{array}{l}93,201 \\
(10.6 \%)\end{array}$ & Adopted \\
\hline $\begin{array}{l}\text { Single liability of } \\
\text { stockholders }\end{array}$ & $\begin{array}{l}751,783 \\
(85.7 \%)\end{array}$ & $\begin{array}{l}29,383 \\
(3.3 \%)\end{array}$ & $\begin{array}{l}96,037 \\
(\mathrm{II} .0 \%)\end{array}$ & Adopted \\
\hline Taxation & & & $\begin{array}{l}507,018 \\
(57.8 \%)\end{array}$ & Not adopted \\
\hline Governor's veto & $\begin{array}{l}458,681 \\
(52.3 \%)\end{array}$ & $\begin{array}{l}338,317 \\
(38.6 \%)\end{array}$ & $\begin{array}{l}80,205 \\
(0.1 \%)\end{array}$ & Adopted \\
\hline Municipal classification & $\begin{array}{l}21,664 \\
(2.5 \%)\end{array}$ & $\begin{array}{l}32, \mathrm{IIO} \\
(3.6 \%)\end{array}$ & $\begin{array}{l}823,429 \\
(93.9 \%)\end{array}$ & Defeated \\
\hline $\begin{array}{l}\text { 9005: Total vote } 96 \mathrm{I}, 505 \\
\text { Tax exemption of } \\
\text { public bonds }\end{array}$ & $\begin{array}{l}655,508 \\
(68.2 \%)\end{array}$ & $\begin{array}{l}139,062 \\
(x 4.4 \%)\end{array}$ & $\begin{array}{l}166,935 \\
(17.4 \%)\end{array}$ & Adopted \\
\hline $\begin{array}{l}\text { State and county elec- } \\
\text { tion to be held in } \\
\text { even years }\end{array}$ & $\begin{array}{l}702,699 \\
(73.1 \%)\end{array}$ & $\begin{array}{l}90,762 \\
(9.4 \%)\end{array}$ & $\begin{array}{l}\text { I68,044) } \\
(\mathrm{I} 7.5 \%)\end{array}$ & Adopted \\
\hline
\end{tabular}

During the period of time that the Ohio party-circle law was effective the Ohio voters voted upon seven constitutional amendments. As shown by Table 12 , five of the seven were adopted. One was not adopted, and one was defeated. Of the five which were adopted, four were endorsed by both the Democratic and the Republican parties, and one was endorsed by the Republicans but opposed by the Democrats. The amendment which was not adopted was endorsed by the Democrats, but the Republicans refused to endorse it, merely advising "careful consideration." Since the law did not provide for such an endorsement, it follows that this amendment was not carried under the Republican party circle. The single amendment which was defeated during this period of time was not indorsed by either party. ${ }^{213}$

${ }^{2 \times 3}$ Dodd, The Revision and Amendment of State Constitutions 197 (rgro). "Under this law amendments that had the support of the two political parties (and in one instance that had the 
Even though the party-circle law had been highly effective, or perhaps for 'this' very reason, the Ohio General Assembly in rgo8 passed an act which amended Section I of the party-circle law of rgo2. This act then proceeded in Section 2 to repeal the entire party-circle law. ${ }^{214}$ There are expressions as to the reasons for the repeal of the party-circle law..$^{255}$ In the fall of $x 908$, after the repeal of the party-circle law, three constitutional amendments were submitted to the Ohio voters. All three of them failed of adoption. The percentage of the voters in the Igo8 general election who failed to vote on these constitutional proposals ranged from $6 x .7$ per cent to 66.x per cent. Thus, Ohio had again made the amendment of its constitution practically impossible.

TABLE 13

\begin{tabular}{|c|c|c|c|c|}
\hline $\begin{array}{l}\text { Year, Total Vote Cast } \\
\text { at Election, and } \\
\text { Description of } \\
\text { Proposed Amendment }\end{array}$ & $\begin{array}{c}\text { Vote for } \\
\text { Proposed } \\
\text { Amendment }\end{array}$ & $\begin{array}{l}\text { Vote against } \\
\text { Proposed } \\
\text { Amendment }\end{array}$ & $\begin{array}{l}\text { Voting at } \\
\text { Election } \\
\text { but Not } \\
\text { Voting for } \\
\text { or against } \\
\text { Proposed } \\
\text { Amendment }\end{array}$ & Result \\
\hline $\begin{array}{l}\text { I908: Total vote I, } 136,525 \\
\text { Repassage of bill over } \\
\text { governor's veto } \\
\text { The time of meeting of } \\
\text { the General Assembly } \\
\text { Removal of limitations } \\
\text { upon the taxing power } \\
\text { of the General As- } \\
\text { sembly }\end{array}$ & $\begin{array}{l}323,770 \\
(28.5 \%) \\
328,362 \\
(28.9 \%)\end{array}$ & $\begin{array}{l}61,754 \\
(5.4 \%) \\
63,006 \\
(5.5 \%)\end{array}$ & $\begin{array}{l}751,001 \\
(66.1 \%) \\
745,157 \\
(65.6 \%)\end{array}$ & $\begin{array}{l}\text { Not adopted } \\
\text { Not adopted }\end{array}$ \\
\hline
\end{tabular}

In Igro a proposition to call a constitutional convention was submitted to the Ohio voters. It carried in a big way, as shown by Table $x 4$.

After the Ohio General Assembly decided to submit the constitutional convention proposal, it re-enacted the principle of the repealed Long-

support of one political party) readily passed and were incorporated in the constitution." Galbreath; op. cit: supra note 207 .

${ }^{214}$ Ohio L. (Igo8), p. I20. Section I as amended provided for the submission of constitutional amendments by printing the proposition in the first column of the official ballot.

"215 Professor Dodd stated that it was repealed for "political reasons," whatever that may mean. Dodd, op. cit. supra note $2 \mathrm{I}_{3}$, at $x 94$.

Galbreath states that, except for the bond exemption amendment, those adopted under the Longwiorth Act proved fairly satisfactory. However, opposition to the veto amendment caused a material modification of it in the Igra convention. "But the exception noted above and the possibility that party leaders might shape the constitution to their will and to the detriment of the people aroused opposition to the Longworth Act and led to its repeal in rgo8." Galbreath, op. cit. supra note 207 , at 94 . 
worth Act, but made it applicable only to the question of calling a constitutional convention. ${ }^{256}$ This act became a law despite the failure of the governor to sign it, and was in effect at the November, rgio, election. The two major parties made use of it. The historian Galbreath states:217

No constitutional amendment was adopted after the repeal of the Longworth Act until I912. The principle of this act, however, was invoked in the law which provided for submitting to the electors of the state the question, "Slall there be a convention to revise, alter or amend the constitution?" This act went into effect May II, rgro.

While neither of the two leading political parties assumed responsibility for the work of the constitutional convention of $19 \mathrm{I} 2$, both of them went on record in favor of holding it and included "constitutional convention, yes" as part of their respective tickets in the fall election of $x 910$. While it is very doubtful whether the proposition

TABLE 14

\begin{tabular}{|c|c|c|c|c|}
\hline $\begin{array}{l}\text { Year, Total Vote Cast } \\
\text { at Election, and } \\
\text { Description of } \\
\text { Proposed Amendment }\end{array}$ & $\begin{array}{l}\text { Vote for } \\
\text { Proposed } \\
\text { Amendment }\end{array}$ & $\begin{array}{l}{ }^{t} \\
\text { Vote against } \\
\text { Proposed } \\
\text { Amendment } \\
\end{array}$ & $\begin{array}{c}\text { Voting at } \\
\text { Election } \\
\text { but Not } \\
\text { Voting for } \\
\text {. or against } \\
\text { Proposed } \\
\text { Amendment }\end{array}$ & Result \\
\hline $93^{2,262}$ & $\begin{array}{l}693,263 \\
(74.4 \%)\end{array}$ & $\begin{array}{l}67,718 \\
(7.2 \%)\end{array}$ & $\begin{array}{l}x 7 x, 28 x \\
(18.4 \%)\end{array}$ & Adopted \\
\hline
\end{tabular}

would have carried if placed in a separate column of the ballot, with the endorsement of the two parties as above described, the result was as follows:

$$
\text { Total } 932,262 \text { For } 693,263 \text { Against } 67,718
$$

The constitutional convention of IgI2 proceeded to propose radical changes in the method of adopting constitutional amendments and in the calling of a constitutional convention.

- Mr. Starbuck Smith, the chairman of the committee on the method of amending the constitution, stated:

At first the committee seemed hopelessly divided. Every member was of the opinion that on this committee rested the greatest work that this convention was called upon to do; to provide a simple and easy method of amending the constitution, because if we do that it matters not so much what else we do; the people will have the machinery whereby they can, in a simple and business-like way, get what they want. ${ }^{218}$

${ }^{216}$ Ohio L. (rgro) p. 169.

${ }^{217}$ Op. cit. supra note 207 , at 94 .

${ }^{258}$ Op. cit. supra note 201 , at $\times 365$. 
The point of view of Mr. Cunningham was similar. He stated:

I think the important thing for this convention-to do, and I believe the proposal accomplishes that, is to make the constitution easily amended, not to make it easy to call a new convention, because I do not think the people of Ohio will be guilty of that offense in the next forty years. I think that is well settled in Ohio, but let us make it easy of amendment. That is my theory about it. It was a mistake in the framers of the constitution of $x 85 \mathrm{I}$, that they made that constitution too difficult to amend, and we have had to resort" to various devices to get it amended. The gentlemen who propose this amendment or this proposal I think have made it quite easy to amend the constitution, and I think if the constitution with this proposal in it is adopted by the people[,] in a very short time they will regard it as the dearest right they have, the ease with which they can amend their constitution. Therefore I heartily agree with the proposal, because it makes it easy to get rid of a bad amendment that may be placed in the constitution. I shall heartily support the proposal as amended by the committee.

These two statements appear fairly to present the attitude of the Ohio convention. There was debate and disagreement about certain aspects of the committee's proposal, but it is significant that no question was raised as to the most substantial change that was proposed. This change abolished the former requirement that a constitutional proposal must receive the approval of a majority of all persons voting for anybody or any measure in a general election. For that provision in the I85I constitution the constitutional convention of IgI2 substituted the following: "If the majority of the electors voting on the same [i.e., amendments] shall adopt such amendments the same shall become a part of the constitution." ${ }^{\prime 2 x 9}$ The committee also proposed, and the convention accepted, a change that provided that amendments shall be submitted "on a separate ballot without party designation of any kind, at either a special or a general election as the General Assembly may prescribe." 2200 This latter provision would seem to eliminate the possibility of using a party-circle law again, but it does not seem to eliminate the Alabama method of voting, ${ }^{22 x}$ which was proposed by the Cook County Illinois Judicial Advisory Council and was embodied in bills that were introduced in the Illinois General Assembly in

${ }^{219}$ Ohio Const., art. I6, $\S \mathrm{I}$, as amended September 3, I9I2. Sections 2 and 3 concerning constitutional conventions have similar provisions.

${ }^{220}$ Ohio Const., art. 16, $\S$ 1, as amended September 3 , xgr2. Section 2 also requires "a separate ballot without party designation of any kind." But Section 3 , which provides for the automatic submission of the question of a constitutional convention every twenty years, has no similar provision, except for the ballot for the election of delegates.

${ }^{22 x}$ Perhaps it would be better to call it the Illinois method of voting, since, as far as is known, it was first used in Illinois on constitutional propositions. ro Univ. Chi. L. Rev. I42, I47, I 53 (1943). 
TABLE $15^{223}$

GENERAL ELECTIONS

\begin{tabular}{|c|c|c|c|c|}
\hline $\begin{array}{l}\text { Year, Total Vote Cast } \\
\text { for Governor, and } \\
\text { Description of } \\
\text { Proposed Amendment }\end{array}$ & $\begin{array}{l}\text { Vote for } \\
\text { Proposed } \\
\text { Amendment }\end{array}$ & $\begin{array}{l}\text { Vote against } \\
\text { Proposed } \\
\text { Amendment }\end{array}$ & $\begin{array}{l}\text { Voting for } \\
\text { Governor } \\
\text { but Not } \\
\text { Voting for } \\
\text { or against } \\
\text { Proposed } \\
\text { Amendment }\end{array}$ & Result \\
\hline \multicolumn{5}{|l|}{ I9r4: Vote for governor } \\
\hline $\begin{array}{l}\text { Local option as to } \\
\text { alcoholic liquor* }\end{array}$ & $\begin{array}{l}559,872 \\
(49.6 \%)\end{array}$ & $\begin{array}{l}547,254 \\
(48.4 \%)\end{array}$ & $\begin{array}{l}22,097 \\
(2.0 \%)\end{array}$ & Adopted \\
\hline Limitation on $\operatorname{tax}$ rate $^{*}$ & $\begin{array}{l}223,873 \\
\text { (I } 9.8 \%)\end{array}$ & $\begin{array}{l}551,760 \\
(48.9 \%)\end{array}$ & $\begin{array}{l}353,590 \\
(31.3 \%)\end{array}$ & Defeated \\
\hline Woman suffrage* & 335,390 & 518,295 & 275,538 & Defeated \\
\hline Prohibition* & $\begin{array}{l}504,177 \\
(44.6 \%)\end{array}$ & $\begin{array}{l}488.970) \\
588,329 \\
(52.1 \%)\end{array}$ & $\begin{array}{l}(24 \cdot 4 \%) \\
36,717 \\
(3 \cdot 3 \%)\end{array}$ & Defeated \\
\hline \multicolumn{5}{|l|}{$\begin{array}{l}\text { I918: Vote for governor } \\
960,862\end{array}$} \\
\hline $\begin{array}{l}\text { Popular referendum } \\
\text { upon legislative action } \\
\text { on amendments to } \\
\text { United States Con- } \\
\text { stitution* }\end{array}$ & $\begin{array}{l}508,282 \\
(52.9 \%)\end{array}$ & $\begin{array}{l}315,030 \\
(32.8 \%)\end{array}$ & $\begin{array}{l}137,550 \\
(14.3 \%)\end{array}$ & Adopted \\
\hline Prohibition* & 463,654 & 437,895 & 59,313 & Adopted \\
\hline $\begin{array}{l}\text { Classification of prop. } \\
\text { erty for purposes of } \\
\text { taxation* }\end{array}$ & $\begin{array}{l}336,6 \mathrm{r6} \\
(35.0 \%)\end{array}$ & $\begin{array}{l}304,399 \\
(3+.7 \%)\end{array}$ & $\begin{array}{r}(0.2 \%) \\
319,847 \\
(33 \cdot 3 \%)\end{array}$ & Adopted \\
\hline $\begin{array}{l}\text { Prohibition of such } \\
\text { double taxation as re- } \\
\text { sults from the taxa- } \\
\text { tion of both real es- } \\
\text { tate and mortgage } \\
\text { debts secured thereby }\end{array}$ & $\begin{array}{l}479,420 \\
(49.9 \%)\end{array}$ & $\begin{array}{l}371,176 \\
(38.6 \%)\end{array}$ & $\begin{array}{l}\text { IIO, 266 } \\
(\mathrm{II} .5 \%)\end{array}$ & Adopted \\
\hline \multicolumn{5}{|l|}{$\begin{array}{l}\text { 1922: Vote for governor } \\
\text { I,625,799 }\end{array}$} \\
\hline $\begin{array}{l}\text { To allow beverage of } \\
2.75 \text { per cent alcohol }\end{array}$ & 719,050 & $908,5^{22}$ & $\begin{array}{l}\text { more voting } \\
\text { on amend- } \\
\text { ment than for } \\
\text { governor }\end{array}$ & Defeated \\
\hline $\begin{array}{l}\text { Debt limitations on all } \\
\text { political subdi- } \\
\text { visions* }\end{array}$ & $\begin{array}{l}499,203 \\
(30.7 \%)\end{array}$ & $\begin{array}{l}691,471 \\
(42.5 \%)\end{array}$ & $\begin{array}{l}435,125 \\
(26.8 \%)\end{array}$ & Defeated \\
\hline Limitation on tax rates $*$ & $\begin{array}{l}475,740 \\
(29 \cdot 3 \%)\end{array}$ & $\begin{array}{l}720,237 \\
(44 \cdot 3 \%)\end{array}$ & $\begin{array}{l}429,822 \\
(26.4 \%)\end{array}$ & Defeated \\
\hline $\begin{array}{c}\text { I926: Vote for governor } \\
\text { I,396,272 }\end{array}$ & & & & \\
\hline $\begin{array}{l}\text { To eliminate compul- } \\
\text { sory primary elec- } \\
\text { tions* }\end{array}$ & $\begin{array}{l}405,142 \\
(29.0 \%)\end{array}$ & $\begin{array}{l}743,313 \\
(53.2 \%)\end{array}$ & $\begin{array}{l}247,8 \mathrm{r} \\
(\mathrm{r} 7.8 \%)\end{array}$ & Defeated \\
\hline
\end{tabular}

${ }^{223}$ The information contained in Tables $\mathrm{I}_{5}$ and $\mathrm{I} 6$ was obtained from John E. Sweeney, Secretary of State of Ohio. He did not furnish data as to the total vote cast in the general elections, but did provide information as to the vote for governor. Amendments marked with an asterisk were proposed by initiative petition. 
TABLE 15-Continued

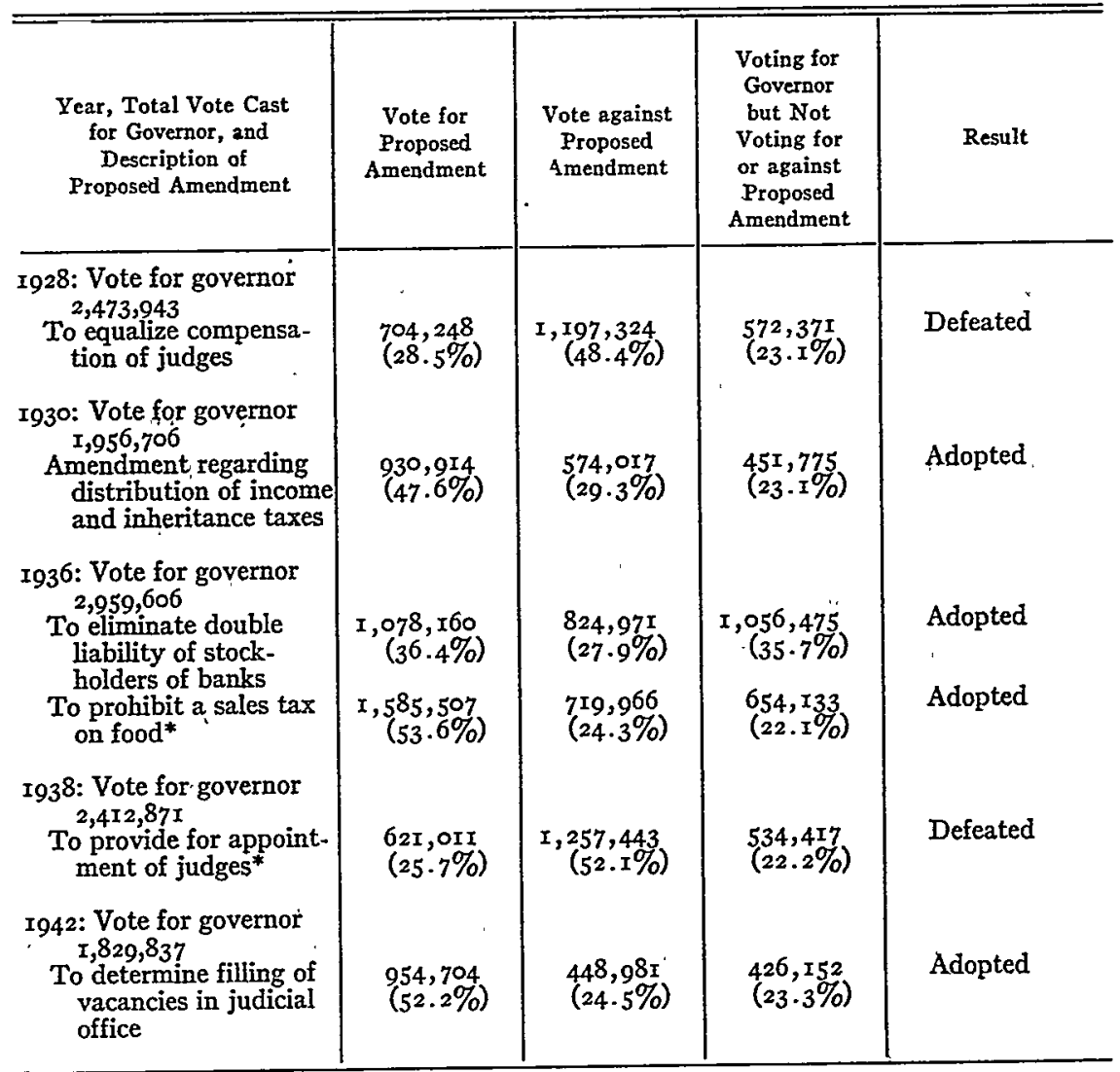

$1943^{222}$ However, the proposed amendments to the amending article of the Ohio constitution were adopted in I9I2, and now the Ohio constitution is in fine shape with reference to future amendments and the calling of constitutional conventions. There is no need for any party-circle method of voting or for any other device like that proposed by the Cook County Judicial Advisory Council. In other words, Ohio is now in line with nearly all the states except the six which are the subject of this particular study. Tables 15 and $x 6$ complete the statistics of voting on constitutional amendments in Ohio since the IgI 2 constitutional convention.

Oklahoma-Amendment of the Oklahoma constitution is complicated from the legal standpoint because of the variety of constitutional and statutory provisions which have been frequently interpreted by the Okla-

${ }^{222}$ Ill. S: B. $33^{6,} 5$ 13; Ill. H. B. $5^{x} 5$, 619. 
TABLE 16

\begin{tabular}{|c|c|c|c|}
\hline $\begin{array}{l}\text { Year of Special Election } \\
\text { and Description of Pro- } \\
\text { posed Amendment }\end{array}$ & $\begin{array}{l}\text { Vote for } \\
\text { Proposed } \\
\text { Amendment }\end{array}$ & $\begin{array}{l}\text { Vote against } \\
\text { Proposed } \\
\text { Amendment }\end{array}$ & Result \\
\hline $\begin{array}{l}\text { 1913: Short ballot for state offices } \\
\text { Short ballot for county and township } \\
\text { officers }\end{array}$ & $\begin{array}{l}239,126 \\
217,875\end{array}$ & $\begin{array}{l}46 \mathrm{r}, 555 \\
449,493\end{array}$ & $\begin{array}{l}\text { Defeated } \\
\text { Defeated }\end{array}$ \\
\hline $\begin{array}{l}\text { Exemption from taxation of state and } \\
\text { municipal lands }\end{array}$ & 312,232 & 340,570 & Defeated \\
\hline $\begin{array}{l}\text { Eligibility of women for appointment } \\
\text { as members of boards or positions in } \\
\text { departments affecting or caring for } \\
\text { women and children }\end{array}$ & 435,222 & $255, \circ 36$ & Adopted \\
\hline Small legislature* & 240,237 & $4 \mathrm{I} 8, \mathrm{x} \mathrm{I} 4$ & Defeated \\
\hline $\begin{array}{l}\text { 1915: Prohibition* } \\
\text { Terms of all county officers to be four } \\
\text { years* }\end{array}$ & $\begin{array}{l}484,969 \\
207,435\end{array}$ & $\begin{array}{l}540,377 \\
604,463\end{array}$ & $\begin{array}{l}\text { Defeated } \\
\text { Defeated }\end{array}$ \\
\hline $\begin{array}{l}\text { To eliminate submission of twice-de- } \\
\text { feated constitutional proposals* }\end{array}$ & $4 \mathrm{I} 7,384$ & 482,275 & Defeated \\
\hline $\begin{array}{l}\text { To exempt state and municipal bonds } \\
\text { from taxation }\end{array}$ & 337,124 & 401,083 & Defeated \\
\hline Igr $7:$ Prohibition* & 522,590 & 523,727 & Defeated \\
\hline $\begin{array}{l}\text { I919: Definition of "intoxicating liquor" } \\
\text { Repeal of state prohibition* } \\
\text { Classification of property for taxation }\end{array}$ & $\begin{array}{l}474,907 \\
454,935 \\
439,897\end{array}$ & $\begin{array}{l}504,688 \\
496,786 \\
5 \mp 7,245\end{array}$ & $\begin{array}{l}\text { Defeated } \\
\text { Defeated } \\
\text { Defeated }\end{array}$ \\
\hline $\begin{array}{l}\text { I921: Soldiers' bonus } \\
\text { To redivide State into senatorial dis- } \\
\text { tricts }\end{array}$ & $\begin{array}{l}949, \text { I09 } \\
336,574\end{array}$ & $\begin{array}{l}324,447 \\
5 \times 8,324\end{array}$ & $\begin{array}{l}\text { Adopted } \\
\text { Defeated }\end{array}$ \\
\hline Poll tax & 244,509 & 672,851 & Defeated \\
\hline $\begin{array}{l}\text { 1923: Increased authority of industrial } \\
\text { commission }\end{array}$ & $588,85^{x}$ & 528,572 & Adopted \\
\hline $\begin{array}{l}\text { Eliminating words "white male" from } \\
\text { state constitution }\end{array}$ & 536,762 & 421,744 & Adopted \\
\hline $\begin{array}{l}\text { Authorizing publication of constitution- } \\
\text { al amendments in newspapers }\end{array}$ & $35^{\mathrm{I}, 5^{\mathrm{I}} 3}$ & 493,786 & Defeated \\
\hline $\begin{array}{l}\text { 1925: Debt limits on political subdivisions } \\
\text { Uniform taxation of real and personal } \\
\text { property }\end{array}$ & $\begin{array}{l}450,218 \\
435,944\end{array}$ & $\begin{array}{l}535,25 I \\
50 I, 22 I\end{array}$ & $\begin{array}{l}\text { Defeated } \\
\text { Defeated }\end{array}$ \\
\hline $\begin{array}{l}\text { Four-year terms for state and county } \\
\text { officers }\end{array}$ & $325,45 \mathrm{I}$ & 543,183 & Defeated \\
\hline I929: Tax limitation & 710,539 & $5^{10}, 874$ & Adopted \\
\hline $\begin{array}{l}\text { I931: To authorize issuance of state } \\
\text { bonds in sum of } \$ 7,500,000,000\end{array}$ & 487,459 & 766,067 & Defeated \\
\hline $\begin{array}{l}\text { 1933: Tax limits on real estate } \\
\text { Amendment relating to township or } \\
\text { county organization } \\
\text { Repeal of state prohibition }\end{array}$ & $\begin{array}{l}979,06 \pi \\
846,594\end{array}$ & $\begin{array}{l}66 \mathrm{I}, \mathrm{I} 5 \mathrm{I} \\
74^{2}, 925\end{array}$ & $\begin{array}{l}\text { Adopted } \\
\text { Adopted }\end{array}$ \\
\hline Repeal of state prohibition & $x, 250,923$ & 578,035 & Adopted \\
\hline
\end{tabular}


homa Supreme Court. In Article V of the Oklahoma constitution provision is made for the initiative and referendum. Amendments to the constitution can be initiated by the voters. Section 3 of Article $V^{224}$ provides in part:

All elections on measures referred to the people of the State shall be had at the next election held throughout the State, except when the Legislature or the Governor shall order a special election for the express purpose of making such reference. Any measure referred to the people by the initiative shall take effect and be in force when it shall have been approved by a majority of the votes cast in such election.

In Atwater v. Hassett, the Oklahoma Supreme Court held that the wellknown "grandfather clause" was legally adopted at a primary election held throughout the state, and that it was not necessary to submit this constitutional amendment at the general November election. ${ }^{225}$ Later, it

${ }_{22+}$ The first three sections of Article $V$ follow:

"Section I. The Legislative authority of the State shall be vested in a Legislature, consisting of a Senate and a House of Representatives; but the people reserve to themselves the power to propose laws and amendments to the Constitution and to enact or reject the same at the polls independent of the Legislature, and also reserve power at their own option to approve or reject at the polls sany act of the Legislature.

"Sec. 2. The first power reserved by the people is the initiative, and eight per centum of the legal voters shall have the right to propose any legislative measure, and fifteen per centum of the legal voters shall have the right to propose amendments to the Constitution by petition, and every such petition shall include the full text of the measure so proposed. The second power is the referendum, and it may be ordered (except as to laws necessary for the immediate preservation of the public peace, health, or safety), either by petition signed by five per centum of the legal voters or by the Legislature as other bills are enacted. The ratio and per centum of legal voters hereinbefore stated shall be based upon the total number of votes cast at the last general election for the State Office receiving the highest number of votes at such election.

"Sec. 3. Referendum petitions shall be filed with the Secretary of State not more than ninety days after the final adjournment of the session of the Legislature which passed the bill on which the referendum is demanded. The veto power of the Governor shall not extend to measures voted on by the people. All elections on measures referred to the people of the State shall be had at the next election held throughout the State, except when the Legislature or the Governor shall order a special election for the express purpose of making such reference. Any measure referred to the people by the initiative shall take effect and be in force when it shall have been approved by a majority of the votes cast in such election. Any measure referred to the people by, the referendum shall take effect and be in force when it shall have been approved by a majority of the votes cast thereon and not otherwise.

"The style of all bills shall be: 'Be It Enacted by the People of the State of Oklahoma.'

"Petitions and orders for the initiative and for the referendum shall be filed with the Secretary of State and addressed to the Governor of the State, who shall submit the same to the people. The Legislature shall make suitable provisions for carrying into effect the provisions of this article."

${ }_{225} 27$ Okla. 292, III Pac. 802 (Igro). On page 296 is this sentence: "Further, the Governor issued his proclamation calling an election for said date at which said proposed amendment was to be submitted." This, however, is not deemed to be the equivalent of a statement that the grandfather clause was adopted at a special election called by the governor. The court does not appear to have considered the primary election as a special election. Cf. State v. Carter, I77 Okla. 382, 59 P. 2 d 948 (I936).

Simpson v. Hill, 128 Okla. 269,263 Pac. 635 (x927) holds that an initiative petition for a statute was not adopted, even though it was voted upon at a special election held October 2 , 
was held that an initiated constitutional amendment could not be submitted at a "run-off" primary election. . $^{26}$ This decision seems questionable; it was adopted by a bare majority of the Oklahoma Supreme Court..27 It was asserted in the majority opinion that a run-off primary election need not necessarily be held in every precinct in the state, because it is possible that candidates by withdrawing from the primary would present "an entire absence of contesting candidates for public offices." ${ }^{228}$ Apparently it was conceded that the particular run-off election would be held throughout the state, and it seems clear that the majority had decided to follow the dictum in Simpson v. Hill and intended to preclude the use of the primary election as well as the run-off primary election unless they were proclaimed to be special elections.

State v. Matheres ${ }^{229}$ is another puzzling decision. There a majority of the Supreme Court of Oklahoma held that an initiated statute was adopted, even though it was apparently conceded that the certificate of the state election board disclosed only that the statute had received a majority of the total vote cast upon that particular proposition. The certificate failed to show the total vote cast upon all of the questions or upon all of

1923, since neither the governor nor the legislature had submitted the petition to this special
election. On rehearing, in a per curiam opinion, reference was made to a statute passed in IgI6.
This statute provided that an initiated measure shall be submitted "at the next regular
election" with a proviso that the governor could submit it at a special election or "designate
the mandatory primary election as a special election for such purpose" (Okla. L. 19I6, p. 89).
In a dictum, this statute was interpreted thus: "This act, by providing that the Governor may
designate the mandatory primary election as a special election, for such purpose, or call a
special election, conclusively shows that the Legislature did not consider a primary election
or special election held throughout the state as a regular election, and it was therefore neces-
sary, before these measures could be voted on at such election that same be submitted thereat
by the Governor." Then reference was made to the action of Governor Trapp in submitting
seven initiative and referendum petitions to the general election in November, r926, rather
than to the primary election held throughout the state in August, I926.

In Looney v. Leeper, I45 Okla. 202, 292 Pac. 365 (I93O) there is a dictum that the language in Section 3 of Article $V$ of the Oklahoma constitution, "the next election held throughout the State," "would include a state-wide primary election." There is also an inference in the opinion that this construction would not apply to Section I, Article 24 of the constitution, providing for the submission of constitutional amendments proposed by the legislature.

${ }^{226}$ State v. Carter, I77 Okla. 382,59 P. $2 \mathrm{~d} 948$ (1936).

${ }^{227}$ It is doubtful whether MCNeill, C.J., did more than agree to the result reached by the majority. He appears to have placed his concurrence on a procedural point.

${ }_{228}$ The majority opinion also states that the language of Section 3 , Article 5 , "next election held throughout the state," has the same meaning as the words "next regular general election" in Section I, Article 24. Furthermore, it was asserted that this had been the administrative construction since the adoption of the constitution.

${ }^{229}$ I34 Okla. 288, 273 Pac. $35^{2}$ (I928). 
the questions and candidates at the state primary election. ${ }^{230}$ This decision was made despite the fact that Section 3 of Article $V$ provides that an initiated measure must be approved "by a majority of the votes in such election." But, as has been seen before, similar language is capable of a variety of interpretations. ${ }^{23 \mathrm{~A}} \mathrm{~A}$ special difficulty, so far as Oklahoma is concerned, is that the Oklahoma Directory on the whole leads one to conclude that the decision in the Matheres case is contrary to some of the apparently confused administrative interpretations in Oklahoma. This is not absolutely certain, because the expression "total vote cast in an election" may seem to be a simple expression, but it is capable of, and has received, varying interpretation. ${ }^{232}$ Suffice to say here that if the Matheres decision should be applied to constitutional amendments, however proposed, then Oklahoma will have to be transferred from its present class and placed in the class of the overwhelming majority, where constitutions can be amended by a majority vote on a particular proposal. ${ }^{233}$

In addition to the power in the voters to initiate constitutional amendments, Oklahoma provides in Article XXIV of its constitution that the legislature may propose amendments to its constitution. ${ }^{234}$ In order to do

${ }^{230} \mathrm{It}$ does not clearly appear whether the statute was voted upon at the primary election of I 28 because it was designated a special election for that purpose. The language on pages 292 and 293 appears to be confusing in this respect. Simpson v. Hill had been decided less than a year previous to this election and State v. Carter had not then been decided. See notes 225, 226 supra.

${ }^{23 x}$ See ro Univ. Chi. L. Rev. I42-46 (r943). The essence of the reasoning of the majority in the Mathews case seems to be this: "Had the initiative measure in question been submitted to the people to be voted upon at a special election called for that express purpose, no one would contend that it would have been required to receive more than a majority of votes cast at such special election, and the fact that it was submitted at a general primary election does not place a greater burden upon its passage, nor upon those who petitioned its submission than would have been had it been submitted at a special election." It is submitted that if the court was assuming a special election called for the single purpose of deciding the fate of the particular measure in question and no other measure or candidate, then its reasoning is faulty. Furthermore, the majority apparently gave no consideration to the part of Section 3 of Article V which immediately follows: "Any measure referred to the people by the referendum shall take effect and be in force when it shall have been approved by a majority of the votes cast thereon and not otherwise" (italics supplied).

${ }_{232}$ See both opinions in State v. State Election Board, I8I Okla. 622, 75 P. 2d 86I (1938).

233 The decision in the case cited supra note 232 would indicate, however, that the Mathews decision will not be applied even to initiated constitutional amendments.

${ }_{234}$ It is suggested in Ramsey v. Persinger, 43 Okla. 4I, I4I Pac. $\mathrm{I}_{3}$ (I9I4) that the methods of amending the Oklahoma constitution are independent of each other. Article XXIV is as follows:

"Section I. Any amendment or amendments to this Constitution may be proposed in either branch of the Legislature, and if the same shall be agreed to by a majority of all the members elected to each of the two houses, such proposed amendment or amendments shall, with the yeas and nays thereon, be entered in their journals and referred by the Secretary of State to the people for their approval or rejection, at the next regular general election, except when the 
this a majority of all members elected to each of the two houses must vote in favor of the proposed amendment. If this occurs, the proposed amendment is to be submitted "at the next regular general election, except when the Legislature, by a two-thirds vote of each house, shall order a special election for that purpose." 235 In order that such a proposed amendment be adopted, it must receive the favorable vote of "a majority of all the electors voting at such election. ...."

This last provision raises the question as to the proper method of determining the total number of electors voting at a particular election. A great deal of light is thrown on this problem by the two opinions in State v. State Election Board. ${ }^{236}$ In the November, I936, election a constitutional amendment submitted by the legislature received a "yes" vote of 379,405 and a "no" vote of 219,996. The question was whether the "yes" vote was a majority of all the electors voting at that election. The state election board certified that the total vote was 767,745 . It arrived at this figure by taking the total number of ballots that were issued to electors, and it subtracted therefrom all the ballots which had been spoiled. This method, according to the minority, included in the total vote the blank ballots, mutilated ballots, and the ballots that were otherwise illegal. According to a certificate made pursuant to a special order of the court, the total vote was 760,055 . This figure was arrived at by adding the highest vote cast and counted in each precinct of the state for any office or measure, as certified by the county election boards. The minority of the court was willing to accept this method of computation, provided that the facts were inves-

Legislature, by a two-thirds vote of each house, shall order a special election for that purpose. If a majority of all the electors voting at such election shall vote in favor of any amendment thereto, it shall thereby become a part of this Constitution.

"If two or more amendments are proposed they shall be submitted in such manner that electors may vote for or against them separately.

"Sec. 2. No convention shall be called by the Legislature to propose alterations, revisions, or amendments to this Constitution, or to propose a new Constitution, unless the law providing for such convention shall first be approved by the people on a referendum vote at a regular or special election, and any amendments, alterations, revisions, or new Constitutions, proposed by such convention, shall be submitted to the electors of the State at a general or special election and be approved by a majority of the electors voting thereon, before the same shall become effective: Provided, That the question of such proposed convention shall be submitted to the people at least once in every twenty years.

"Sec. 3. This article shall not impair the right of the people to amend this Constitution by a vote upon an initiative petition therefor."

${ }_{235}$ Observe that the governor is not authorized to call this special election. Cf. Art. V, $\S 3$. To call a special election it is not sufficient to have the assent of two-thirds of a quorum of each house. State v. State Board of Equalization, ro7 Okla. Ir8, 230 Pac. 743 (1924). See also Looney v. Leeper, I45 Okla. 202, 292 Pac. 365 ( 1930 ).

${ }^{236}$ See note 232 supra. 
tigated with reference to the allegation that in eighty-one precincts errors had been made which would reduce the figure to $75^{6}, 455$. A third possibility of determining the total vote was to accept the highest vote cast and counted for any office or measure for which all the electors of the state were entitled to vote. This figure was 749,740 , the total vote cast and counted for presidential electors. Neither the majority nor the minority was willing to accept this third method. The majority of the court did not decide which of the first two methods was correct. It observed that the amendment failed to receive a majority on either basis. The majority held that the supreme court was not the forum in which to investigate the allegation of errors in eighty-one precincts and thus to determine whether the figure of 760,055 should be reduced.

There are interesting comments in the minority opinion that prior to I 9 í 6 the administrative practice in Oklahoma was to determine the total vote cast by ascertaining the total vote for the office of governor, and that the practice since I9I6 had not been consistent. The majority asserted that since Igr 6 the method advocated by the state election board, in this particular case, had been followed.

Section 2 of Article XXIV provides for a constitutional convention. A proposition to assemble a convention must "be approved by the people ${ }^{237}$ on a referendum vote at a regular or special election. . . . ." It is also provided that the question of a constitutional convention shall be submitted at least once in every twenty years.

The first session of the Legislative Assembly of Oklahoma passed a statute which provided for a blanket ballot to include all candidates for office..$^{28} \mathrm{It}$ also provided for an official referendum ballot on which, apparently, all state questions were to be printed..$^{239} \mathrm{It}$ is reasonably clear that this referendium ballot was separate and distinct from the candidates ballot, and this' has been the uniform practice in Oklahoma from the beginning of its statehood..$^{20}$ The ordinary method of voting on state questions

23.7 Observe that here it is not specified whether the approval shall be by a majority of those voting on the proposition or by a majority of those voting at the election. But the work of the convention is to be approved "by a majority of the electors voting thereon" at a general or special election.

${ }_{238}^{8}$ Oklahoma, L. 1907-8 S. B. No. 23 (ch. 3I) Art. IV. Cf. S. B. I68 (ch. 31) § 9, providing for primary elections. In I $9 \circ 9$ the Massachusetts ballot was adopted, abolishing party columns and party circles and placing all candidates and measures on one ballot. Oklahoma L., I909, ch. 16, pp. 251, 26r. But this law was repealed in I910. Oklahoma L., I910, p. 237.

239 Ibid., H. B. I74 (ch. 44), \$\$. 7, IO, I4.

${ }^{240}$ Information received from J. Wm. Cordell, Secretary of the Oklahoma State Election Board. See Okla. L., I9I3, p. IrI (ch. 7O). 
consists of placing a cross in a square opposite the word "yes" or the word "no." "24r

In its I9Io session the Oklahoma legislature adopted the Illinois-Alabama method of voting on constitutional amendments when submitted after a prescribed fashion. It was first provided that if the legislature desired to ascertain the sentiment of the people on a proposed amendment it could by a concurrent resolution suggest this proposal to the citizens. Then it was provided that if citizens proceeded to initiate "such proposition within one year thereafter," the proposition would then be printed "either on a separate and independent ballot or upon the ballot upon which the names of candidates appear, should such election occur upon the day when candidates are being voted for." In the latter event, the proposition was to appear immediately following the names of the candidates. $^{242}$ In either case, the proposition was to be followed by these words, "For the Amendment." It will be observed that the negative of the proposition, to wit, "Against the Amendment," was not to be printed on the ballot. Then it was provided: "Should the elector desire to vote for the proposed amendment he shall leave the words, 'For the Amendment,' intact without erasing same. But should he desire to vote against such proposition he shall strike out the words, 'For the Amendment,' with a pencil mark. When such words are so erased after any proposition, the ballot shall be recorded as having been cast against the same, and whenever they are not so erased, such ballot shall be recorded as having been voted for such proposition." ${ }^{243}$

The grandfather clause of the Oklahoma constitution was adopted at the primary election in Igro by the use of this method of voting. ${ }^{244}$ This Illinois-Alabama method of voting was again used in Igr6 in voting upon a proposed constitutional amendment which was apparently designed to take the place of the grandfather clause, ${ }^{245}$ after that clause had been de-

${ }_{24 x}$ See note 239 supra, $\S$ Io.

${ }_{242}$ As demonstrated by the results in Mlinois and Ohio during the last decade of the nineteenth century, this was the most obscure position in which constitutional proposals could be placed. Query: Was it compulsory to place the grandfather clause on the candidates ballot, since it was submitted at a primary election? It would be interesting to know just what happened in this respect.

${ }_{243}$ Oklahoma, L., Igro, ch. 66, art. 2, pp. I24-27 (S. B. No. 126). See In re Initiative State Question No. 10, 26 Okla. 554, Iro Pac. 647 (19ro).

${ }_{244}$ Oklahoma, L., Igro, p. 284, Senate Concurrent Resolution No. 3 I; Atwater v. Hassett, 27 Okla. 292, I Ir Pac. 802 (19I0). It relies chiefly on the Alabama case that approved of this method of voting. See ro Univ. Chi. L. Rev. 142, 47 (1943).

${ }_{245}$ Oklahoma, L., I9I6, pp. 144-47. It was provided that this proposed amendment should be printed "on a separate and independent ballot, or, any ballot on which Constitutional Amendments or other propositions submitted by the Legislature to the people for approval 
clared by the Supreme Court of the United States to be in violation of the Fifteenth Amendment. ${ }^{24}$ The proposed amendment was defeated, and as far as is known this has ended the use of the Illinois-Alabama method of voting in Oklahoma. But the statute which provides for it is still a part of the Oklahoma statutory law and can still be used. ${ }^{247}$

The constitutional proposals which have been submitted to the voters of Oklahoma have been arranged in two tables which follow. The first table is an attempt to include all proposals which were submitted at general elections. Whatever the Oklahoma nomenclature may be, these general elections were the primary elections and the final elections in November. They were elections at which all electors were entitled to express themselves upon the various candidates for the various offices. In the second table will be listed those proposals which were submitted at special elections, i.e., elections for the purpose of voting upon legislative or constitutional propositions and at which; as far as is known, no candidates for office were nominated or elected.

In the main the information set forth in Tables 17 and 18 was derived from the Directory of the State of Oklahoma for 194r. ${ }^{248}$ This information was checked by an examination of the Oklahoma constitution, all of the Session Laws down to and including I943, and various court decisions. It has not been possible to reconcile everything found in the Directory with the information available in the other sources. The impression made is that in the early days, at least, Oklahoma officials were confused by their elaborate system of amending their constitution, and that their records were not made or kept with the utmost care. However, it may be possible for one who is familiar with Oklahoma history and customs to explain many records that seem confused or erroneous. Despite whatever errors there may be, Oklahoma has voted so frequently upon constitutional proposals that, for the purposes for this article, valuable conclusions can be drawn even if a certain percentage of error is conceded. Therefore, no effort will be wasted in attempting to specify what seem to be all of the errors or at least all of the confusion in the records.

or rejection may be placed." The proposed amendment was submitted as the second proposition at the I9I6 primary election along with eight other propositions. Oklahoma Directory, r94I, pp. I34-35. Presumably the law was followed and the proposed amendment was submitted under the Illinois-Alabama method of voting, but the submission was not on the candidates ballot. If the submission had been on the candidates ballot, the result might have been different.

${ }^{246}$ Guinn and Beal v. United States 238 U.S. 347 (I9I5). See also Lane v. Wilson, 307 U.S. 268 (I939).

${ }_{447}$ O Oklahoma St. (Harlow, $\left.x 93 x\right) \S \S 5894-97$ inc. ${ }^{248} \mathrm{Pp}$. 129 to $\mathrm{4}_{4} 8$ inc. 
TABLE 17

\section{GENERAL ELECTIONS}

\begin{tabular}{|c|c|c|c|c|}
\hline $\begin{array}{l}\text { Year, Total Vote Cast } \\
\text { at Election, and } \\
\text { Description of } \\
\text { Proposed Amendment }\end{array}$ & $\begin{array}{l}\text { Vote for } \\
\text { Proposed } \\
\text { Amendment }\end{array}$ & $\begin{array}{l}\text { Vote against } \\
\text { Proposed } \\
\text { Amendment }\end{array}$ & $\begin{array}{c}\text { Voting at } \\
\text { Election } \\
\text { but Not } \\
\text { Voting for } \\
\text { or 2gainst } \\
\text { Proposed } \\
\text { Amendment }\end{array}$ & Result \\
\hline \multicolumn{5}{|l|}{ November, 1908: Total } \\
\hline $\begin{array}{l}\text { State agency to dispense } \\
\text { intoxicating liquors }\end{array}$ & $\begin{array}{l}105,392 \\
(42.3 \%)\end{array}$ & $\begin{array}{l}\text { I2I, } 573 \\
(48.9 \%)\end{array}$ & $\begin{array}{l}21,829 \\
(8.8 \%)\end{array}$ & Defeated \\
\hline $\begin{array}{l}\text { Established Torrens } \\
\text { land registration } \\
\text { system }\end{array}$ & $\begin{array}{l}\text { II } 4,394 \\
(46.0 \%)\end{array}$ & $\begin{array}{c}83,888 \\
(33.7 \%)\end{array}$ & $\begin{array}{c}50,512 \\
(20.3 \%)\end{array}$ & Not adopted \\
\hline $\begin{array}{l}\text { Method of selecting } \\
\text { state capitol }\end{array}$ & $\begin{array}{l}\text { I20,352 } \\
(48.4 \%)\end{array}$ & $\begin{array}{l}71,933 \\
(28.9 \%)\end{array}$ & $\begin{array}{c}56,509 \\
(22.7 \%)\end{array}$ & Not adopted \\
\hline Sale of public lands & $\begin{array}{c}96,754 \\
(38.9 \%)\end{array}$ & $\begin{array}{l}\text { I10,840 } \\
(44.5 \%)\end{array}$ & $\begin{array}{l}41,200 \\
(16.6 \%)\end{array}$ & Defeated \\
\hline \multicolumn{5}{|l|}{ August, rgro: Total vote } \\
\hline $\begin{array}{l}\text { Grandfather clause; } \\
\text { qualification of } \\
\text { electors }\end{array}$ & 135,443 & 106,222 & & Adopted \\
\hline \multicolumn{5}{|l|}{ November, I9ro: Total } \\
\hline $\begin{array}{l}\text { Established a district } \\
\text { for state institutions }\end{array}$ & $\begin{array}{l}84,366 \\
(34.1 \%)\end{array}$ & $\begin{array}{l}118,899 \\
(48.0 \%)\end{array}$ & $\begin{array}{l}44,401 \\
(\mathrm{I} 7.9 \%)\end{array}$ & Defeated \\
\hline Woman suffrage & $\begin{array}{l}88,808 \\
(35.8 \%)\end{array}$ & $\begin{array}{l}128,928 \\
(52.1 \%)\end{array}$ & $\begin{array}{c}29,930 \\
(12.1 \%)\end{array}$ & Defeated \\
\hline $\begin{array}{l}\text { Creation of state elec- } \\
\text { tion board } 230\end{array}$ & $\begin{array}{l}80,146 \\
(32.4 \%)\end{array}$ & $\begin{array}{l}\text { 106,459 } \\
(43.0 \%)\end{array}$ & $\begin{array}{l}6 I, 06 I \\
(24.6 \%)\end{array}$ & Defeated \\
\hline $\begin{array}{l}\text { Sale of intoxicating } \\
\text { liquor in municipali- } \\
\text { ties }\end{array}$ & $\begin{array}{l}\text { I05,04T } \\
(42.4 \%)\end{array}$ & $\begin{array}{l}\mathrm{I} 26, \mathrm{II} 8 \\
(50.9 \%)\end{array}$ & $\begin{array}{l}16,507 \\
(6.7 \%)\end{array}$ & Defeated \\
\hline
\end{tabular}

${ }_{349}$ The total number of persons voting on the grandfather clause, strange as it may seem, exceeded the total vote at the election. This may be explained by the discussion concerning the case cited in note 232 supra. Observe that three of the propositions submitted at the August rgr6 election received more votes than the stated total vote. It is true that the Directory does not state in so many words the total vote cast at the elections. But it states that the vote necessary to carry in I910 was 120,333 . Since, in order to carry, a constitutional amendment upon an initiated petition must receive a majority of the total number of voters at the election, it is possible to calculate the total number of voters by subtracting one from the vote necessary to carry and then multiplying the latter figure by two. Thus, we arrive at the figure 240,664 as the total vote at the primary election, August 2, Igro.

${ }^{250} \mathrm{It}$ is very doubtful whether this was a constitutional amendment. The records available make it uncertain. But the Directory states the vote necessary to carry this proposition was 123,834, the same as that necessary to carry propositions at this election which were clearly constitutional amendments. If the proposition was a statute that was referred to the voters, then apparently only a majority of those voting on the particular proposition was necessary to sustain it. Observe Art. V., $\S 3$ of the Oklahoma constitution: "Any measure referred to the people by the referendum shall take effect and be in force when it shall have been approved by a majority of the votes cast thereon and not otherwise." 
TABLE 17-Continued

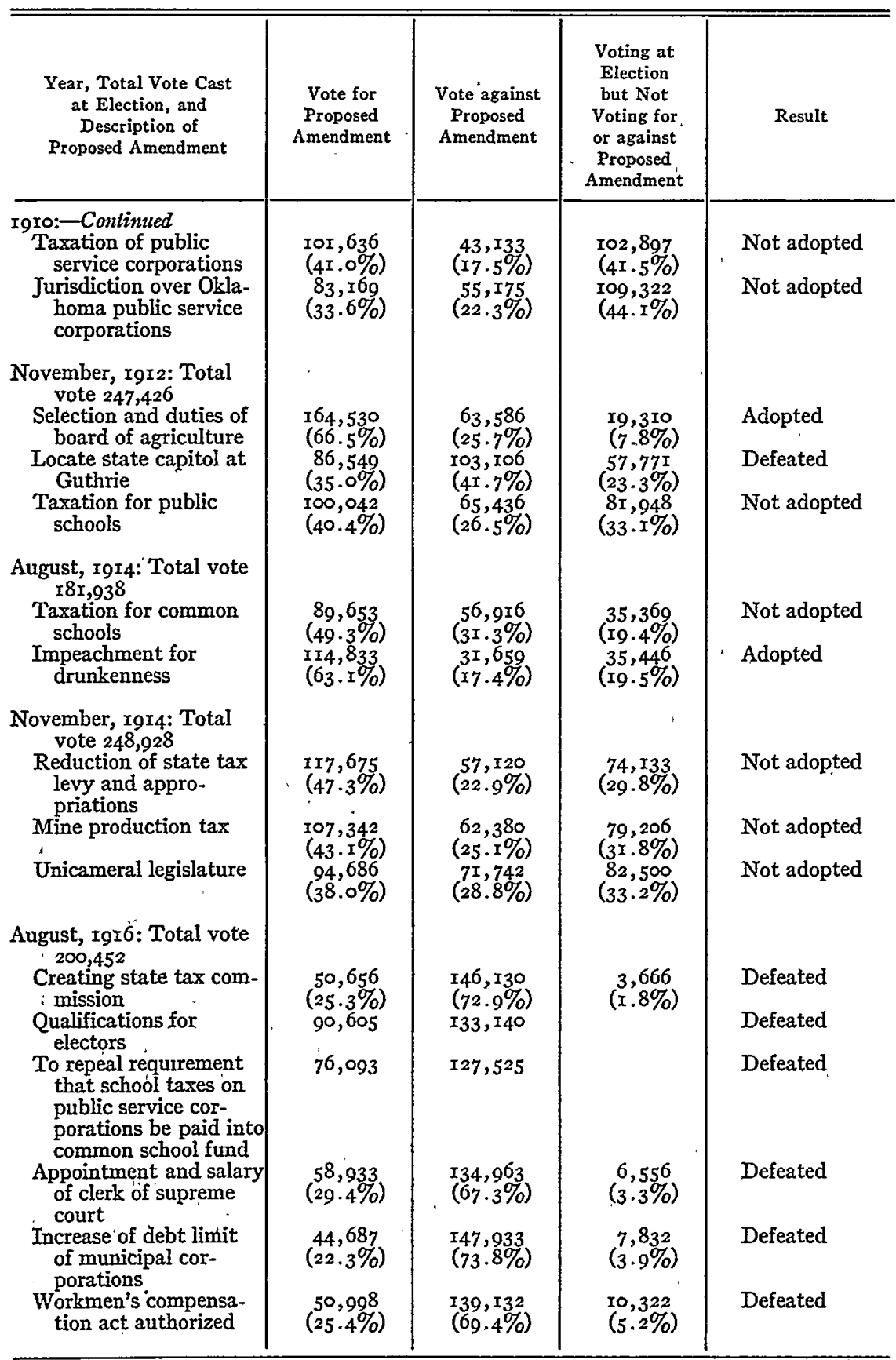


TABLE 17-Continued

\begin{tabular}{|c|c|c|c|c|}
\hline $\begin{array}{l}\text { Year, Total Vote Cast } \\
\text { at Election, and } \\
\text { Description of } \\
\text { Proposed Amendment }\end{array}$ & $\begin{array}{l}\text { Vote for } \\
\text { Proposed } \\
\text { Amendment }\end{array}$ & $\begin{array}{l}\text { Vote against } \\
\text { Proposed } \\
\text { Amendment }\end{array}$ & $\begin{array}{l}\text { Voting at } \\
\text { Election } \\
\text { but Not } \\
\text { Voting for } \\
\text { or against } \\
\text { Proposed } \\
\text { Amendment }\end{array}$ & Result \\
\hline $\begin{array}{l}\text { 1916:- Continued } \\
\text { Consolidation of sup- } \\
\text { preme court and } \\
\text { criminal court of } \\
\text { appeals }\end{array}$ & $\begin{array}{c}42,896 \\
(21.4 \%)\end{array}$ & $\begin{array}{l}149,272 \\
(74.5 \%)\end{array}$ & $\begin{array}{l}8,284 \\
(4.1 \%)\end{array}$ & Defeated \\
\hline Size of juries & $\begin{array}{l}49,954 \\
(24.9 \%)\end{array}$ & $\begin{array}{l}142,333 \\
(7 \mathrm{I} .0 \%)\end{array}$ & $\begin{array}{l}8,165 \\
(4.1 \%)\end{array}$ & Defeated \\
\hline $\begin{array}{l}\text { Abolition of county } \\
\text { court }\end{array}$ & 47,194 & I 57,284 & & Defeated \\
\hline $\begin{array}{l}\text { November, 19I6: Total } \\
\text { vote } 304,106\end{array}$ & & & & \\
\hline $\begin{array}{l}\text { Creation of state elec- } \\
\text { tion board to replace } \\
\text { existing boards }\end{array}$ & $\begin{array}{l}x 47,067 \\
(48.4 \%)\end{array}$ & $\begin{array}{l}\text { II } 9,602 \\
(39.3 \%)\end{array}$ & $\begin{array}{l}37,437 \\
(12.3 \%)\end{array}$ & Not adopted \\
\hline $\begin{array}{l}\text { To prevent legislature } \\
\text { from passing a regis- } \\
\text { tration law; requiring } \\
\text { the use of the initiative }\end{array}$ & $\begin{array}{l}140,366 \\
(46.1 \%)\end{array}$ & $\begin{array}{l}\mathrm{II} 4,824 \\
(37.8 \%)\end{array}$ & $\begin{array}{l}48,916 \\
(16.1 \%)\end{array}$ & Not adopted \\
\hline $\begin{array}{l}\text { November, I9I8: Total } \\
\text { vote } 194,533^{\circ}\end{array}$ & & & & \\
\hline Woman suffrage & $\begin{array}{l}\text { 106, } 909 \\
(55.0 \%)\end{array}$ & $\begin{array}{c}8 \mathrm{r}, 48 \mathrm{r} \\
(4 \mathrm{I}, 9 \%)\end{array}$ & $\begin{array}{c}6,140 \\
(3.1 \%)\end{array}$ & Adopted \\
\hline $\begin{array}{l}\text { November, I920: Total } \\
\text { vote } 489,166\end{array}$ & & & & \\
\hline $\begin{array}{l}\text { School tax on public } \\
\text { service corporations }\end{array}$ & 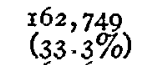 & $\begin{array}{l}x 79,271 \\
(36.6 \%)\end{array}$ & $\begin{array}{l}I 47, I 46 \\
(30.1 \%)\end{array}$ & Defeated \\
\hline $\begin{array}{l}\text { Additional school tax } \\
\text { on all property }\end{array}$ & $\begin{array}{l}+69,639 \\
(34.7 \%)\end{array}$ & $\begin{array}{l}188,574 \\
(38.5 \%)\end{array}$ & $\begin{array}{l}\mathrm{I} 30,953 \\
(26.8 \%)\end{array}$ & Defeated \\
\hline $\begin{array}{l}\text { To authorize mutual } \\
\text { insurance companies }\end{array}$ & $\begin{array}{l}157,064 \\
(32,1 \%)\end{array}$ & $\begin{array}{l}159,919 \\
(32.7 \%)\end{array}$ & $\begin{array}{l}\text { I72, } 183 \\
(35.2 \%)\end{array}$ & Defeated \\
\hline $\begin{array}{l}\text { Compensation of legis- } \\
\text { lators and legislative } \\
\text { procedure }\end{array}$ & $\begin{array}{l}\mathrm{r} 25,463 \\
(25.6 \%)\end{array}$ & $\begin{array}{l}173,274 \\
(35.5 \%)\end{array}$ & $\begin{array}{l}\text { rgo, } 429 \\
(38.9 \%)\end{array}$ & Defeated \\
\hline $\begin{array}{l}\text { August, I922: Total vote } \\
\text { not stated } \\
\text { Increase of ad } \\
\text { valorem tax rate }\end{array}$ & $13^{6,647}$ & $19 x, 180$ & & Defeated \\
\hline $\begin{array}{l}\text { November, 1922: Total } \\
\text { vote } 520,562 \\
\text { Soldier's bonus }\end{array}$ & $\begin{array}{l}255,887 \\
(49.2 \%)\end{array}$ & $\begin{array}{l}234,909 \\
(45.1 \%)\end{array}$ & $\begin{array}{l}29,766 \\
(5 \cdot 7 \%)\end{array}$ & Not adopted \\
\hline $\begin{array}{l}\text { November, 1926: Total } \\
\text { vote } 395,172 \\
\text { Increase compensation } \\
\text { of legislators and } \\
\text { legislative procedure }\end{array}$ & $\begin{array}{c}54, \infty 7 \\
(13.7 \%)\end{array}$ & $\begin{array}{l}251,332 \\
(63.6 \%)\end{array}$ & $\begin{array}{c}89,833 \\
(22.7 \%)\end{array}$ & Defeated \\
\hline
\end{tabular}


TABLE 17-Continued

\begin{tabular}{|c|c|c|c|c|}
\hline $\begin{array}{l}\text { Year, Total Vote Cast } \\
\text { at Election, and } \\
\text { Description of } \\
\text { Proposed Amendment }\end{array}$ & $\begin{array}{l}\text { Vote for } \\
\text { Proposed } \\
\text { Amendment }\end{array}$ & $\begin{array}{l}\text { Vote against } \\
\text { Proposed } \\
\text { Amendment }\end{array}$ & $\begin{array}{c}\text { Voting at } \\
\text { Election } \\
\text { but Not } \\
\text { Voting for } \\
\text { or against } \\
\text { Proposed } \\
\text { Amendment }\end{array}$ & Result \\
\hline $\begin{array}{l}\text { I926:-Continued } \\
\text { Special tax levy for }\end{array}$ & I05, 588 & 223,625 & 65,959 & Defeated \\
\hline $\begin{array}{l}\text { Constitutional con- } \\
\text { vention }\end{array}$ & $\begin{array}{l}(20.7 \%) \\
47,510 \\
(12.0 \%)\end{array}$ & $\begin{array}{l}(50.0 \%) \\
24 \pi, 040 \\
(61.0 \%)\end{array}$ & $\begin{array}{l}(10.7 \%) \\
106,622 \\
(27.0 \%)\end{array}$ & Defeated \\
\hline $\begin{array}{l}\text { Qualifications of speci- } \\
\text { fied state officials }\end{array}$ & $\begin{array}{l}242,656 \\
(47.5 \%)\end{array}$ & $\begin{array}{l}119,338 \\
(23.3 \%)\end{array}$ & $\begin{array}{l}149,326 \\
(29.2 \%)\end{array}$ & Not adopted \\
\hline $\begin{array}{l}\text { Separate board of re- } \\
\text { gents for state agri- } \\
\text { cultural and mechani- } \\
\text { cal colleges }\end{array}$ & $\begin{array}{l}\mathrm{I} 8 \mathrm{o}, 0 \mathrm{OI} \\
(35.2 \%)\end{array}$ & $\begin{array}{l}167,763 \\
(32.8 \%)\end{array}$ & $\begin{array}{l}x 63,543 \\
(32.0 \%)\end{array}$ & Not adopted \\
\hline $\begin{array}{l}\text { Board of regents for } \\
\text { University of Okla- } \\
\text { homa }\end{array}$ & $\begin{array}{l}\text { I7r }, 906 \\
(33.6 \%)\end{array}$ & $\begin{array}{l}164,813 \\
(32.2 \%)\end{array}$ & $\begin{array}{l}174,6 \text { or } \\
(34.2 \%)\end{array}$ & Not adopted \\
\hline $\begin{array}{l}\text { July, r932: Total vote } \\
47 \mathrm{I}, 448\end{array}$ & & & & \\
\hline $\begin{array}{l}\text { To change limits on ad } \\
\text { valorem tax rates }\end{array}$ & $\begin{array}{l}195,042 \\
(41.4 \%)\end{array}$ & $\begin{array}{l}229,27 \circ \\
(48.6 \%)\end{array}$ & $\begin{array}{l}47,136 \\
(10.0 \%)\end{array}$ & Defeated \\
\hline $\begin{array}{l}\text { November, } 1934: \text { Total } \\
\text { vote } 639,938\end{array}$ & & & & \\
\hline $\begin{array}{l}\text { To authorize municipal } \\
\text { police pensions }\end{array}$ & $\begin{array}{l}302,618 \\
(47 \cdot 3 \%)\end{array}$ & $\begin{array}{l}183,855 \\
(28.7 \%)\end{array}$ & $\begin{array}{l}\text { I53,465 } \\
(24.0 \%)\end{array}$ & Not adopted \\
\hline $\begin{array}{l}\text { Restrictions upon con- } \\
\text { solidations of public } \\
\text { service corporątions }\end{array}$ & $\begin{array}{l}254,631 \\
(39.8 \%)\end{array}$ & $\begin{array}{l}\text { I55,330 } \\
(24.3 \%)\end{array}$ & $\begin{array}{l}229,977 \\
(35.9 \%)\end{array}$ & Not adopted \\
\hline $\begin{array}{l}\text { July, r936: Total vote } \\
\text { not stated } 25 x\end{array}$ & & & & \\
\hline Care of needy persons & $346,95^{\circ}$ & 210,888 & & Adopted \\
\hline $\begin{array}{l}\text { November, } 1936: \text { Total } \\
\text { vote } 767,746\end{array}$ & & & & \\
\hline $\begin{array}{l}\text { To authorize municipal } \\
\text { police pensions }\end{array}$ & $\begin{array}{l}390,142 \\
(50.8 \%)\end{array}$ & $\begin{array}{l}232,310 \\
(30.3 \%)\end{array}$ & $\begin{array}{l}I 45,294 \\
(18.9 \%)\end{array}$ & Adopted \\
\hline $\begin{array}{l}\text { Separate board of re- } \\
\text { gents for agricultural } \\
\text { and mechanical } \\
\text { schools }\end{array}$ & $\begin{array}{l}379,405 \\
(49.4 \%)\end{array}$ & $\begin{array}{l}219,996 \\
(28.7 \%)\end{array}$ & $\begin{array}{l}\text { ז68,343 } \\
(2 \mathrm{r} .9 \%)\end{array}$ & Not adopted \\
\hline $\begin{array}{l}\text { Repeal of prohibition } \\
\text { and establishment of } \\
\text { state liquor system }\end{array}$ & $\begin{array}{l}267,285 \\
(34.8 \%)\end{array}$ & $\begin{array}{l}39 r, 083 \\
(50.9 \%)\end{array}$ & $\begin{array}{l}\text { rog, } 378 \\
\text { (14.3\%) }\end{array}$ & Defeated \\
\hline
\end{tabular}

${ }^{25 x}$ The Oklahoma Directory for 194 I states that the vote necessary to carry this proposition was 278,920 . This is merely a majority of the vote cast upon the particular amendment, and leaves the impression that the amendment could have been adopted by such a vote. This seems contrary to Article V, Section 3 of the Oklahoma Constitution, which provides: "Any measure referred to the people by the initiative shall take effect and be in force when it shall have been approved by a majority of the votes cast in such election." 
TABLE 17-Continued

\begin{tabular}{|c|c|c|c|c|}
\hline $\begin{array}{l}\text { Year, Total Vote Cast } \\
\text { at Election, and } \\
\text { Description of } \\
\text { Proposed Amendment }\end{array}$ & $\begin{array}{l}\text { Vote for } \\
\text { Proposed } \\
\text { Amendment }\end{array}$ & $\begin{array}{c}\text { Vote against } \\
\text { Proposed } \\
\text { Amendment } \\
\text { - }\end{array}$ & $\begin{array}{l}\text { Voting at } \\
\text { Election } \\
\text { but Not } \\
\text { Voting for } \\
\text { or against } \\
\text { Proposed } \\
\text { Amendment }\end{array}$ & Result \\
\hline \multicolumn{5}{|l|}{$\begin{array}{l}\text { November, I938: Total } \\
\text { vote not stated }\end{array}$} \\
\hline $\begin{array}{l}\text { To permit municipal } \\
\text { indebtedness for } \\
\text { municipal utilities }\end{array}$ & 98,216 & 266,893 & & Defeated \\
\hline $\begin{array}{l}\text { Pensions and benefits } \\
\text { for employees in state } \\
\text { schools }\end{array}$ & $\begin{array}{c}183,997 \\
-\end{array}$ & 218,945 & & Defeated \\
\hline $\begin{array}{l}\text { To reduce number of } \\
\text { legislators and estab- } \\
\text { lish annual salaries }\end{array}$ & 92,264 & $25^{6,745}$ & & Defeated \\
\hline \multicolumn{5}{|l|}{ November, r940: Total } \\
\hline $\begin{array}{l}\text { vote } 847,770 \\
\text { To levy additional } \\
\text { graduated tax on land } \\
\text { in excess of a section } \\
\text { for old age security }\end{array}$ & $\begin{array}{l}408,559 \\
(48.2 \%)\end{array}$ & $\begin{array}{l}\text { I96,7II } \\
(23.2 \%)\end{array}$ & $\begin{array}{l}242,500 \\
(28.6 \%)\end{array}$ & Not adopted \\
\hline $\begin{array}{l}\text { To make women eligible } \\
\text { for specified state } \\
\text { offices }\end{array}$ & $\begin{array}{l}354,433 \\
(4 \mathrm{I} .8 \%)\end{array}$ & $\begin{array}{l}169,926 \\
(20.0 \%)\end{array}$ & $\begin{array}{l}323,4 \mathrm{II} \\
(38.2 \%)\end{array}$ & Not adopted \\
\hline $\begin{array}{l}\text { To regulate public } \\
\text { service corporations } \\
\text { in consolidating or } \\
\text { controlling parallel or } \\
\text { competing lines of } \\
\text { other public service } \\
\text { corporations }\end{array}$ & $\begin{array}{l}256,466 \\
(30.2 \%)\end{array}$ & $\begin{array}{l}210,890 \\
(24.9 \%)\end{array}$ & $\begin{array}{l}380,414 \\
(44.9 \%)\end{array}$ & Not adopted \\
\hline $\begin{array}{l}\text { To regulate the manu- } \\
\text { facture, transporta- } \\
\text { tion and sale of alco- } \\
\text { holic beverages }\end{array}$ & $\begin{array}{l}290,752 \\
(34.3 \%)\end{array}$ & $\begin{array}{l}374,9 \mathrm{Ix} \\
(44.2 \%)\end{array}$ & $\begin{array}{l}182,107 \\
(21.5 \%)\end{array}$ & Defeated \\
\hline \multicolumn{5}{|l|}{ November, I942: Total } \\
\hline $\begin{array}{l}\text { To authorize legislature } \\
\text { to provide retirement } \\
\text { allowances and death } \\
\text { and/or disability } \\
\text { benefits for teachers } \\
\text { and other employees } \\
\text { of schools supported } \\
\text { wholly or in part by } \\
\text { public funds }\end{array}$ & $\begin{array}{l}125,229 \\
(31.2 \%)\end{array}$ & $\begin{array}{l}\text { I7I, } 433 \\
(42.8 \%)\end{array}$ & $\begin{array}{l}\text { 104,256 } \\
(26.0 \%)\end{array}$ & Defeated \\
\hline $\begin{array}{l}\text { To prevent abrogation } \\
\text { of recovery for dam- } \\
\text { ages for injuries re- } \\
\text { sulting in death or } \\
\text { any statutory limita- } \\
\text { tion except as } \\
\text { specially provided }\end{array}$ & $\begin{array}{l}I 44,846 \\
(36.1 \%)\end{array}$ & $\begin{array}{l}\text { I08,452 } \\
(27.1 \%)\end{array}$ & $\begin{array}{l}147,620 \\
(36.8 \%)\end{array}$ & Not adopted \\
\hline $\begin{array}{l}\text { To provide age and } \\
\text { residence require- } \\
\text { ments for elective } \\
\text { state officials }\end{array}$ & $\begin{array}{l}201,763 \\
(50.3 \%)\end{array}$ & $\begin{array}{l}98,013 \\
(24.5 \%)\end{array}$ & $\begin{array}{l}101,142 \\
(25.2 \%)\end{array}$ & Adopted \\
\hline
\end{tabular}


TABCE 18

SPECIAL, ELECTIONS

\begin{tabular}{|c|c|c|c|c|}
\hline $\begin{array}{l}\text { Year, Total Vote Cast } \\
\text { at Election, and } \\
\text { Description of } \\
\text { Proposed Amendment }\end{array}$ & $\begin{array}{c}\text { Vote for } \\
\text { Proposed } \\
\text { Amendment }\end{array}$ & $\begin{array}{l}\text { Vote against } \\
\text { Proposed } \\
\text { Amendment }\end{array}$ & $\begin{array}{l}\text { Voting at } \\
\text { Election } \\
\text { but Not } \\
\text { Voting for } \\
\text { or against } \\
\text { Proposed } \\
\text { Amendment } \\
\text { As2 }\end{array}$ & Result \\
\hline $\begin{array}{l}\text { June, Igro: Total vote } \\
\text { not stated } \\
\text { Foreign transportation } \\
\text { corporations required } \\
\text { to appoint a resident } \\
\text { agent }\end{array}$ & 53,784 & 108,205 & & Defeated \\
\hline $\begin{array}{l}\text { April, rgIr: Total vote } \\
88,430 \\
\text { Foreign transportation } \\
\text { corporations required } \\
\text { to appoint a resident } \\
\text { agent }\end{array}$ & $\begin{array}{c}41,768 \\
(47.2 \%)\end{array}$ & $\begin{array}{c}46,662 \\
(52.8 \%)\end{array}$ & & - Defeated \\
\hline $\begin{array}{l}\text { August, I913: Total vote } \\
\text { about } 95,000^{253} \\
\text { Regulation of the sale, } \\
\text { lease, or purchase of } \\
\text { transportation com- } \\
\text { panies }\end{array}$ & $\begin{array}{c}59,437 \\
(62.6 \%)\end{array}$ & $\begin{array}{c}35,115 \\
(36.9 \%)\end{array}$ & $\begin{array}{c}448 \\
(0.5 \%)\end{array}$ & Adopted \\
\hline $\begin{array}{l}\text { School taxes upon pub- } \\
\text { lic service corpora- } \\
\text { tions to be paid into } \\
\text { common school fund }\end{array}$ & $\begin{array}{c}63,330 \\
(66,7 \%)\end{array}$ & $\begin{array}{c}30,295 \\
(3 \times .9 \%)\end{array}$ & $\begin{array}{l}I, 375 \\
(\mathrm{r} .4 \%)\end{array}$ & Adopted \\
\hline $\begin{array}{l}\text { Abolish or establish } \\
\text { township government } \\
\text { Creation of new board } \\
\text { of agriculture }\end{array}$ & $\begin{array}{c}50,634 \\
(53 \cdot 3 \%) \\
67,367 \\
(70.9 \%)\end{array}$ & $\begin{array}{c}39,690 \\
(4 \mathrm{x} .8 \%) \\
25,087 \\
(26,4 \%)\end{array}$ & $\begin{array}{l}4,676 \\
(4.9 \%) \\
2,546 \\
(2.7 \%)\end{array}$ & $\begin{array}{l}\text { Adopted } \\
\text { Adopted }\end{array}$ \\
\hline $\begin{array}{l}\text { May, rgrg: Total vote } \\
\text { 24I,244 } \\
\text { Bond issue for hard- } \\
\text { surfaced highways } 254\end{array}$ & $\begin{array}{r}69,917 \\
(29.0 \%)\end{array}$ & $\begin{array}{l}\text { I7I, 327 } \\
(71.0 \%)\end{array}$ & & Defeated \\
\hline $\begin{array}{l}\text { October, 1923: Total vote } \\
289,100 \\
\text { Workmen's compensa- } \\
\text { tion }\end{array}$ & $\begin{array}{l}r 37,358 \\
(47.5 \%)\end{array}$ & $\begin{array}{l}\text { I20, } 76 \mathrm{I} \\
(4 \mathrm{I} .8 \%)\end{array}$ & $\begin{array}{c}30 ; 98 \mathrm{I} \\
(10.7 \%)\end{array}$ & Not adopted \\
\hline
\end{tabular}

${ }^{252}$ Since this table deals exclusively with special elections at which no candidates were to be nominated or elected, the number of those not voting on a particular amendment would probably be small. They would include only those voters who were interested enough to vote at the election on at least one proposition, but not sufficiently interested to vote on another proposition or propositions.

253 This figure was obtained from the opinion in Ramsey v. Persinger, 43 Okla. 4I, I4I Pac. I3 (IgI4).

254 The Oklahoma Directory states that the vuce necessary to carry this amendment was $120,59 \mathrm{I}$. This seems to be incorrect in view of the fact that the total vote on the proposition was 241,244 . A majority of 'the latter figure would be $x 20,623$. However, this discrepancy is not material in view of the fact that the amendment was decisively defeated. No other amendment was submitted at this particular election. 
TABLE 18-Continued

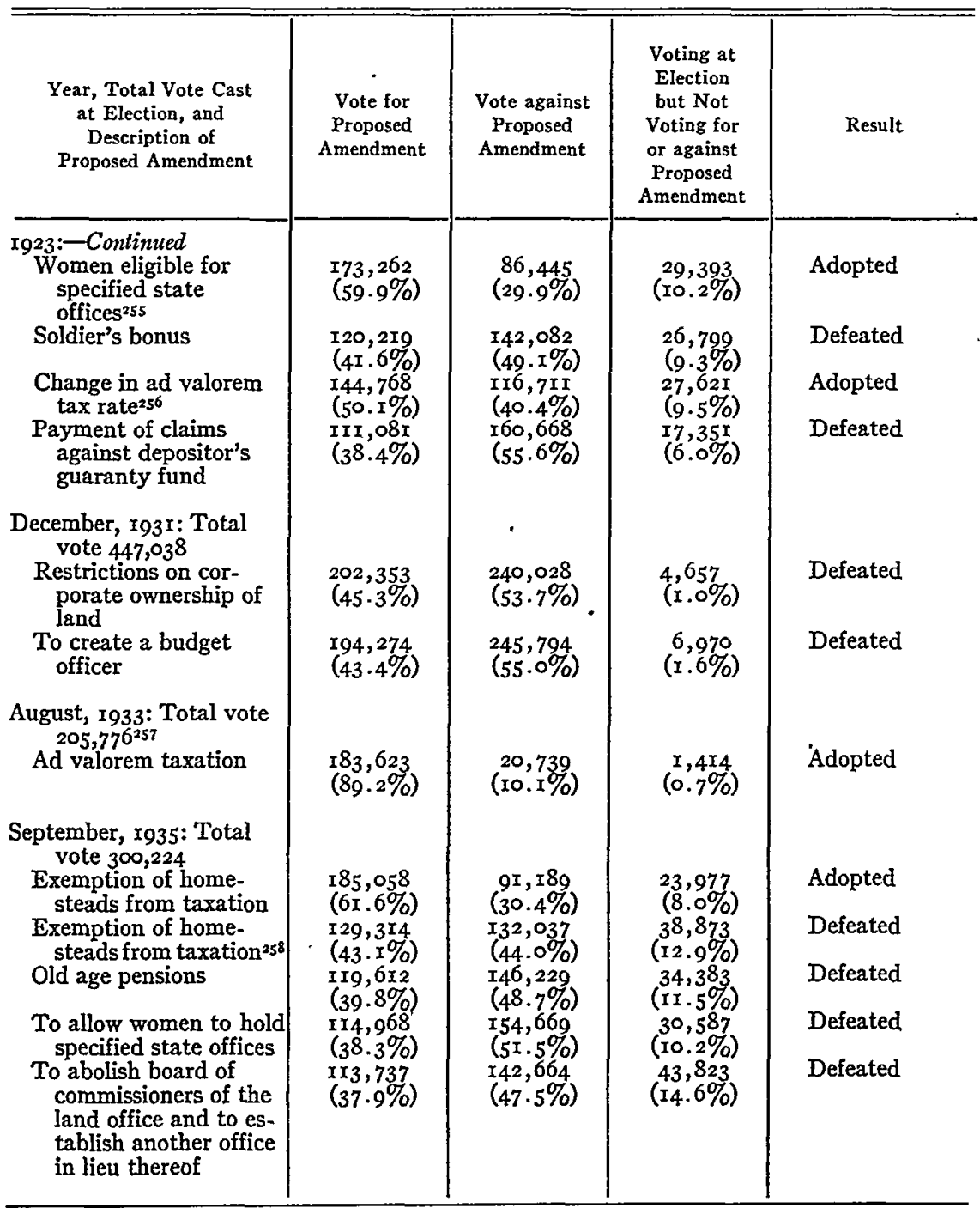

${ }_{255}$ Looney v.Leeper, ${ }_{45}$ Okla. 202, 292 Pac. 365 (I930), held that this proposed amendment was improperly submitted at this special election and that it was not adopted legally. It ordered a re-submission of the amendment at the November, 1930, election.

${ }^{256}$ State v. State Board of Equalization, Io7 Okla. II8, 230 Pac. 743 (1924), held that this proposed amendment was improperly submitted at this special election and that therefore it was ineffective.

${ }^{257}$ While there was only one constitutional amendment submitted at this special election, there were two other propositions presented to the voters.

${ }^{258}$ The first two propositions in this special election were similar. The first was proposed by an initiative petition; the second was submitted by the legislature. 
TABLE 18-Continued

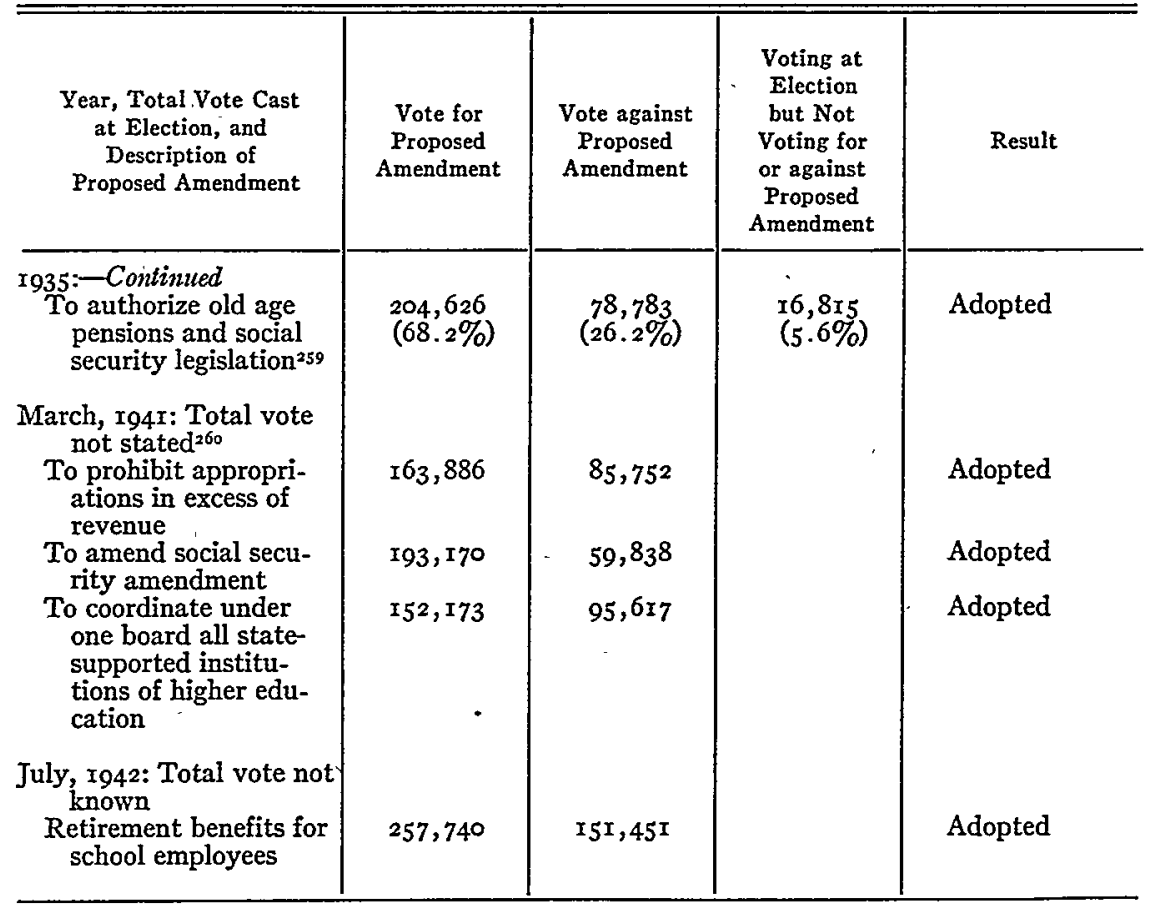

Conchusions-Out of sixty constitutional proposals submitted at general elections only seven, or II per cent, of them were adopted. One of these was adopted by using the Illinois-Alabama method of voting. That is about what one should expect under the restrictive method of adoption in the Illinois group of states. It is to be observed, however, that the Oklahoma voters, while somewhat temperamental about their voting on amendments, have been more interested in voting on them than Illinois voters have been. In Oklahoma the highest percentage of non-voters has been 44.9 per cent. Only thrice have the non-voters equaled 40 per cent. Four times the voters have exceeded the stated total vote. In Illinois, beginning

259 This proposed amendment was declared invalid because it was submitted contrary to law. Associated Industries of Oklahoma v. Oklahoma Tax Commission, r76 Okla. 120, 55 P. 2d 79 (1936). Observe that it is stated in the opinion that the affirmative vote on the proposal was 204,522 .

${ }^{260}$ The OkJahoma Directory does not state the result as to any one of the three amendments submitted at this special election, March II, I94I. However, the highest vote cast on the three amendments was 253,008 . If this may be considered the total vote or close to it, then the vote necessary to carry any amendment was 126,505. Thus, it would appear that all three amendments were adopted. The Session Laws for I94I, pp. 547 to 552 inc., states that these three amendments were adopted. 
with I924, the smallest percentage of non-voters has been $4 \mathrm{I}$ per cent and the largest 62.I per cent. It is the special election that has been the main factor in the amendment of the Oklahoma constitution.

Tennessee-The Tennessee constitution of 18 70 has never been amended. Neither has a constitutional convention been called since that year. These facts have resulted in much discussion in Tennessee as to the possibility of meeting modern problems by changing certain provisions of its I870 constitution. ${ }^{26 x}$

Amending the Tennessee constitution by proposals submitted by the Tennessee General Assembly is an exceedingly difficult procedure. As far as is known, it is the most difficult of any state in the Union. Article XI, Section 3 , of the Tennessee constitution ${ }^{262}$ provides that before a proposed amendment may be submitted to the voters, it must first pass the two Houses of the Tennessee General Assembly "by a majority of all the members elected to each of the two Houses. . ..."The second important step in the procedure requires a proposed amendment, which has met the first hurdle, to "be agreed to by two-thirds of all the members elected to each House" of the General Assembly "then next to be chosen." The third step requires a proposed amendment to be approved and ratified "by a majority of all the citizens of the State, voting for Representatives. . . . ." Not satisfied with these restrictions, the Tennessee constitution also provides that "the Legislature shall not propose amendments to the Constitution oftener than once in six years."

${ }^{26 x}$ Combs and Cole, Tennessee-A Political Problem 27, 28-46 inc. (I940); 32 Am. Pol. Sci. Rev. 514 (1938); McClure, State Constitution Making 347, 349, 354 (r9I6). Other discussions are cited in these publications.

${ }_{263}$ "Any amendment or amendments to this Constitution may be proposed in the Senate or House of Representatives; and, if the same shall be agreed to by a majority of all the members elected to each of the two Houses, such proposed amendment or amendments shall be entered on their journals, with the yeas and nays thereon, and referred to the General Assembly then next to be chosen; and shall be published six months previous to the time of making such choice; and if, in the General Assembly then next chosen as aforesaid, such proposed amendment or amendments shall be agreed to by two-thirds of all the members elected to each House, then it shall be the duty of the General Assembly to submit such proposed amendment or amendments to the people, in such manner, and at such times as the General Assembly shall prescribe. And if the people shall approve and ratify such amendment or amendments, by a majority of all the citizens of the State, voting for Representatives, voting in their favor, such amendment or amendments shall become a part of this Constitution. When any amendment or amendments to the Constitution shall be proposed, in pursuance of the foregoing provisions, the same shall, at each of the said sessions, be read three times on three several days in each House. The Legislature shall not propose amendments to the Constitution oftener than once in six years. The Legislature shall have the right, at any time, by law, to submit to the people the question of calling a Convention to alter, reform, or abolish this Constitution, and when, upon such submission, a majority of all the votes cast shall be in favor of said proposition, then delegates shall be chosen, and the Convention shall assemble in such mode and manner as shall be prescribed." 
However, there is no limitation on the number of amendments that may be submitted every sixth year. Despite these restrictions amendments have been submitted. The first one was submitted at a special election in $1887,{ }^{263}$ and concerned the prohibition of intoxicating liquor, a subject easy to understand and one which arouses much feeling. It was defeated by a majority of 27,730 of those voting on the issue. The vote for and against this amendment was $26,75^{\circ}$ in excess of the vote for governor, and it is likely that the vote for governor was in excess of the vote for representatives. However, the vote on the prohibition amendment was in an odd year while that for governor was in an even year. Aside from this first proposed amendment, the remainder have received affirmative-votes that have never exceeded one-fourth of the vote for governor. ${ }^{2{ }^{2} 4}$

The Tennessee constitution permits proposed amendments to be submitted at either a general election or a special election, but even though they are submitted at a special election, it seems to be the understanding that the vote for them, in order to adopt them, must be a majority of those voting for representatives. ${ }^{265} \mathrm{It}$. seems to be uncertain whether the vote for representatives will be the vote at the general election preceding the special election or the vote for the representatives at the general election next following the special election. One may guess that it will be the vote at the general election preceding the special election. That will make it possible to declare the result of a special election as soon as the vote has been ascertained.

The seven amendments submitted in I904 were voted upon at the November general election. The method of voting upon these amendments is not clear. Section 2 of the act submitting them provides:

Sec. 2. Be it further enacted, That each of said proposed Constitutional amendments shall be printed or written upon the ballots to be voted in said general election.

In counties, towns and civil districts where Section 5, Chapter 24, Acts extra session of $I 890$ is applicable, the manner of voting shall be as therein provided.

${ }^{263}$ Tennessee, Acts (I887) pp. $x 67,424$. General elections in Tennessee for some officers are held on the first Thursday in August of the even-numbered years and for other officers on the first Tuesday after the first Monday in November of the even-numbered years. Tenn. Const. art. $7, \S 5$; art. $2, \S 7$; art. $3, \S 2$; Combs and Cole, op. cit. supra note $26 \mathrm{I}$, at 58 .

${ }^{264}$ Combs and Cole, op. cit. supra note $26 I$, at 40 .

${ }_{265}$ Such could be inferred to be the belief of Combs and Cole. Apparently, however, the total vote for representatives in Tennessee is not determined. In the apparent absence of that, the total vote for governor is used by Combs and Cole.

Professor Henry $\mathbf{N}$. Williams of the political science department of Vanderbilt University and a native of Tennessee wrote this to the author: "... . should a case arise I have no doubt that the courts would hold that this limitation on voting applied even though the proposed amendment had been voted on at a special election. Doubtless the vote for representatives in the previous general election would be the base for comparison." 
A cross mark $(X)$ opposite the word "yes" will indicate that the person so marking his ballot desires to vote for the amendment and the ballot will be so counted.

Ballots for use in this election at all voting precincts where said Section 5 , Chapter 24, Acts extra session of $x 890$ does not apply, shall be as now provided by law, except that Section I, Chapter 2I, extra session of I8gr, is hereby amended so as to substitute 6 inches instead of 3 inches to designate the width of ballots, but this amendment shall apply only to ballots for use in said general election November, I9O4.

The matter to go upon these ballots shall be arranged in two columns.

Names of offices and candidates to be voted for shall be printed or written, as heretofore, in the first column and the proposed Constitutional amendments as set out in the caption of this Act, shall be printed in the second column.

A voter may scratch, mark out or cancel any of the proposed amendments, and ballots shall be counted for all amendments not so scratched. ${ }^{266}$

An effort was made to understand the meaning of this section by reading the specified statutes and by consulting the Tennessee Code of $I 896$ and the supplement to that code for $1897-$-1903. This effort was not rewarded with much understanding. Apparently, however, the Tennessee code at that time differentiated between counties of 50,000 or more inhabitants and counties of less than 50,000 inhabitants. ${ }^{267}$ In counties of the first class it appears that voting upon constitutional amendments was to be accomplished by the familiar method of placing a cross mark opposite the word "yes" or the word "no" as the voter chose. In counties of the second class it does not appear that any provision of this sort was made. ${ }^{268}$ Therefore, the act of 1903 , which submitted the seven amendments, would seem to have been of particular importance as to the method of voting in counties of less than 50,000.269 Observe this language: "A voter may scratch, mark out or cancel any of the proposed amendments, and ballots shall be counted for all amendments not so scratched." This language, without further explanation, would seem to provide for the Illinois-Alabama method of voting, which has been previously discussed. ${ }^{270}$ But the meaning of this language is not clear and without more it is difficult to believe that Tennessee provided for the ordinary method of voting on constitutional amendments in the larger counties, and at the same time provided for a radically different and a very drastic method of voting in the more rural

${ }^{266}$ Tenn. Acts, I903, ch. 532, pp. I410-I5. Cf. Tenn. Acts (1887) ch. 86 providing for the form of the "tickets" and the returns to be made of the special election on the prohibition amendment.

${ }^{267}$ But the act of 1890 referred to in Section 2 differentiates between counties of 70,000 and over and cities of 9,000 and over and counties and cities of less population. Tenn. Acts ( $1890-$ 91) ch. 24, p. 5o. Cf. Tenn. Acts (I8gI) chs. 224, 225, pp. 438-40.

${ }^{268}$ Tenn. Code (1896) pp. $382-90$. Cf. Art. IX with Art. X.

${ }^{269}$ Cf. note 267 supra, which would seem to require 70,000 to be used in place of 50,000.

${ }^{270}$ See note $242-47$, supra. 
counties. However, it will be observed that in Section 2 of the act of I9०3, submitting the amendments, it is provided that, in the more populous counties, a cross mark opposite the word "yes" will be counted in favor of the amendment. Why is there no statement that a cross mark opposite the word "no" will be counted against the amendment? This question and others will have to remain unanswered. Perhaps some person who knows the history and the ramifications of the Tennessee statutes can explain the doubts and answer the questions.

It is also interesting to observe that in Section 3 of the act of I903, submitting the amendments, the county commissioners of election were required to certify to the secretary of state the vote cast in each county for the proposed amendments and the vote cast for representatives. Again it will be observed that there is no requirement that there shall be a certification of the vote cast against the amendments. This would seem to be the explanation for the failure to record the negative vote in the secretary of state's office. But one is puzzled to know why Professors Combs and Cole failed to set forth in their table the vote cast for representatives rather than the vote cast for governor.

Table I 9 is based upon figures which appear in a study made by a member and a former member of the University of Tennessee faculty. They secured their figures on the popular voting by an examination of records in the state capitol. ${ }^{27 x}$ As far as is known, these figures have not been published elsewhere. As will be observed, however, this information is not complete. The information as to the two amendments submitted in I940 was secured from Joe C. Carr, the secretary of state of Tennessee.

The Tennessee constitution of $x 870$ provides very briefly for the calling of a constitutional convention. Here is the language on that subject:

The Legislature shall have the right, at any time, by law, to submit to the people the question of calling a Convention to alter, reform or abolish this Constitution, and when, upon such submission, a majority of all the votes cast shall be in favor of said proposition, then delegates shall be chosen, and the Convention shall assemble in such mode and manner as shall be prescribed.

This provision is notable for its vagueness. To begin with, there is no provision as to the majority of the legislators who must vote in favor of a resolution calling a convention. In the absence of a definite requirement, it is possible, if there is a quorum present in each House, that a majority of that quorum by voting in favor of a resolution to call a convention can submit it to the voters. At most, it would seem that no more than a mere 
TABLE 19

AMENDMENTS

\begin{tabular}{|c|c|c|c|c|}
\hline $\begin{array}{l}\text { Year, Nature of Election, } \\
\text { Vote for Governor, and } \\
\text { Description of } \\
\text { Proposed Amendment }\end{array}$ & $\begin{array}{l}\text { Vote for } \\
\text { Proposed } \\
\text { Amendment }\end{array}$ & $\begin{array}{l}\text { Vote against } \\
\text { Proposed } \\
\text { Amendment }\end{array}$ & $\begin{array}{l}\text { Voting at } \\
\text { Election } \\
\text { but Not } \\
\text { Voting for } \\
\text { or against } \\
\text { Proposed } \\
\text { Amendment }\end{array}$ & Result \\
\hline $\begin{array}{l}\text { x887: Special election: } \\
\text { Vote for governor } \\
235,988 \\
\text { Prohibition }\end{array}$ & 117,504 & 145,234 & & Defeated \\
\hline $\begin{array}{l}\text { 1904: General election: } \\
\text { Vote for governor } \\
236,021 \\
\text { Limitation on local } \\
\text { governmental in- } \\
\text { debtedness }\end{array}$ & 50,353 & & & Defeated \\
\hline $\begin{array}{l}\text { Popular election of } \\
\text { secretary of state }\end{array}$ & 58,975 & & & Defeated \\
\hline $\begin{array}{l}\text { Popular election of } \\
\text { treasurer and comp- } \\
\text { troller }\end{array}$ & 57,757 & & & Defeated \\
\hline $\begin{array}{l}\text { Local legislation to be } \\
\text { permitted on roads, } \\
\text { game, and fences }\end{array}$ & $5^{6,290}$ & & & Defeated \\
\hline $\begin{array}{l}\text { Exemption of manu- } \\
\text { facturers from tax- } \\
\text { ation by local govern- } \\
\text { ments }\end{array}$ & $5^{2}, 5^{17}$ & & & Defeated \\
\hline $\begin{array}{l}\text { Four-year term for } \\
\text { governor }\end{array}$ & 57,834 & & & \\
\hline $\begin{array}{l}\text { Increase in terms of some } \\
\text { county officers }\end{array}$ & 57,363 & & & Defeated \\
\hline $\begin{array}{l}\text { I935: Special election:272 } \\
\text { Vote for governor }\end{array}$ & & & & - \\
\hline $\begin{array}{l}240,235 \\
\text { Increase in per diem of } \\
\text { legislators }\end{array}$ & $\begin{array}{l}15,167 \\
(6.3 \%)\end{array}$ & $\begin{array}{l}59,309 \\
(24.7 \%)\end{array}$ & $\begin{array}{l}165,759 \\
(69.0 \%)\end{array}$ & Defeated \\
\hline $\begin{array}{l}\text { I940: General election: } \\
\text { Vote for governor } \\
448,720\end{array}$ & & & & \\
\hline $\begin{array}{l}\text { Compensation of mem- } \\
\text { bers of General } \\
\text { Assembly }\end{array}$ & $\begin{array}{l}558,216 \\
(35 \cdot 3 \%)\end{array}$ & $\begin{array}{l}77,614 \\
(17.3 \%)\end{array}$ & $\begin{array}{l}212,89 \circ \\
(47.4 \%)\end{array}$ & Not adopted \\
\hline $\begin{array}{l}\text { Governor's term of } \\
\text { service }\end{array}$ & $\begin{array}{l}\text { I7x,209 } \\
(38.1 \%)\end{array}$ & $\begin{array}{c}68,5 \circ 6 \\
(15.3 \%)\end{array}$ & $\begin{array}{l}209,005 \\
(46.6 \%)\end{array}$ & Not adopted \\
\hline
\end{tabular}

${ }_{272}$ The table in Combs and Cole, note 26r, supra, sets forth 1935 as the year of the election and that would be a special election. The table in the Review, note 261, supra, sets forth r932. The chances are that that would have been a general election. An effort to discover the law or resolution providing for this election was unsuccessful. 
majority of the members elected to each House could submit such a resolution.

After a resolution for a convention is submitted to the voters, it has been decided that the majority required to adopt the resolution is a majority of the votes cast upon the proposition, rather than a majority of all votes at a general election..$^{273}$

It will be observed that the Tennessee constitution is silent as to any requirement concerning the ratification of the work of a constitutional convention. Thus, there is nothing explicit in its constitution to prevent a convention from passing a resolution that would declare the amendments which it had framed and adopted, or even a totally new constitution, to be in effect without a popular vote thereupon. Similar action has occurred in modern times, particularly in southern states. ${ }^{274}$ There is nothing, however, to prevent a convention from submitting its recommendations to popular ratification; but the Tennessee constitution is silent as to whether this will be at a special or general election and as to the vote required for ratification.

Table 20 is based upon information secured by Professors Combs and Cole. ${ }^{275} \mathrm{It}$ will be observed that all attempts to assemble a constitutional convention in Tennessee since 1870 have failed. But it will also be observed that the failure has been due to the fact that Tennessee voters on that proposition have cast more votes against a convention than for it. Because of the decision in the Derryberry case, it is believed that there is no unreasonable or unusual barrier to securing a constitutional convention in Tennessee, whenever a majority of the voters on that question, and that question alone, determine that they want a convention. The trouble in Tennessee is that a majority of its voters, who have voted on the question, have been conservative, not to say reactionary, in their attitude toward a constitutional convention. But they are not handicapped as to a conyention, by a provision similar to that in the Illinois constitution. ${ }^{276}$ A majority of those voters in Tennessee who are sufficiently interested in the proposition to vote upon it can alter their constitution through the

${ }^{273}$ Derryberry v. State Board of Election Com'rs, I5o Tenn. 525, 266 S.W. 102 (1924). The reasoning of the opinion makes it clear that the decision would be the same if the proposition to call a convention were submitted at a special election.

$274 \mathrm{McCl}$ (ure, op. cit. supra note $26 \mathrm{I}$, at $35 \mathrm{I}$.

${ }^{275}$ Note $26 \mathrm{x}$ supra at 37 . See also $32 \mathrm{Am}$. Pol. Sci. Rev. 514, 516 (1938).

${ }^{276} \mathrm{Ill}$. Const., art. I4, § I. First, the proposal must be approved by "two-thirds of the members of each house of the General Assembly." Then "the question shall be submitted to the electors at the next general election." But a convention is to be assembled only "if a majority voting at the election vote for a convention" (italics supplied). 
convention method under a very elastic procedure, whenever they convince themselves that that is what they desire. . $^{27}$

Tennessee has the Massachusetts form of ballot. "The names of all candidates for the same office shall be printed together, and arranged alphabetically according to the initials of their surnames, irrespective of party." This is copied from the Dortch Ballot Law which also provides:

TABLE 20

CONSTITUTIONAL CONVENTIONS

\begin{tabular}{|c|c|c|c|c|}
\hline $\begin{array}{l}\text { Year, Nature of } \\
\text { Election, Vote } \\
\text { for Governor }\end{array}$ & $\begin{array}{l}\text { Vote for } \\
\text { Proposed } \\
\text { Convention }\end{array}$ & $\begin{array}{c}\text { Vote against } \\
\text { Proposed } \\
\text { Convention }\end{array}$ & $\begin{array}{l}\text { Voting at } \\
\text { Election } \\
\text { but Not } \\
\text { Voting for } \\
\text { or against } \\
\text { Proposed } \\
\text { Convention }\end{array}$ & ' Result \\
\hline $\begin{array}{l}\text { 1897: Special election. } \\
\text { Vote for governor, } \\
320,580\end{array}$ & $\begin{array}{l}22,450 \\
(7.0 \%)\end{array}$ & $\begin{array}{l}\mathrm{II} 3, \mathrm{I} 58 \\
(35.3 \%)\end{array}$ & $\begin{array}{l}184,972 \\
(57.7 \%)\end{array}$ & Defeated \\
\hline $\begin{array}{l}\text { IgI6: Vote for governor, } \\
266,64 \mathrm{I}\end{array}$ & $\begin{array}{l}63,940 \\
(24.0 \%)\end{array}$ & $\begin{array}{c}67,335 \\
(25.2 \%)\end{array}$ & $\begin{array}{l}\mathrm{T} 35,366 \\
(50.8 \%)\end{array}$ & Defeated \\
\hline $\begin{array}{l}\text { I917: Special election. } \\
\text { Vote for governor, } \\
266,64 \mathrm{I}\end{array}$ & $\begin{array}{l}20,903 \\
(7.9 \%)\end{array}$ & $\begin{array}{c}85,16 x \\
(3 r .9 \%)\end{array}$ & $\begin{array}{l}160,577 \\
(60.2 \%)\end{array}$ & Defeated \\
\hline $\begin{array}{l}\text { 19r9: Special election. } \\
\text { Vote for governor, } \\
158,147\end{array}$ & $\begin{array}{l}7,680 \\
(4.9 \%)\end{array}$ & $\begin{array}{l}4 r, 839 \\
(26.4 \%)\end{array}$ & $\begin{array}{l}\text { '108,628 } \\
(68.7 \%)\end{array}$ & Defeated \\
\hline $\begin{array}{l}\text { x924: Vote for governor, } \\
283,119\end{array}$ & $\begin{array}{l}93,081 \\
(32.9 \%)\end{array}$ & $\begin{array}{l}135,875 \\
(48.0 \%)\end{array}$ & $\begin{array}{c}54, \mathrm{I} 63 \\
\text { (19.r\%) }\end{array}$ & Defeated \\
\hline $\begin{array}{l}\text { 1926: Vote for governor, } \\
\text { I3I,217 }\end{array}$ & $\begin{array}{c}27,978 \\
(21.3 \%)\end{array}$ & $\begin{array}{l}43,335 \\
(33.0 \%)\end{array}$ & $\left(\begin{array}{c}59,904 \\
(45.7 \%)\end{array}\right.$ & Defeated \\
\hline $\begin{array}{l}\text { r93r: Special election. } \\
\text { Vote for governor, } \\
240,235\end{array}$ & $\begin{array}{l}9,685 \\
(4.0 \%)\end{array}$ & $\begin{array}{c}49,313 \\
(20.5 \%)\end{array}$ & $\begin{array}{l}18 \mathrm{I}, 237 \\
(75.5 \%)\end{array}$ & Defeated \\
\hline
\end{tabular}

"Whenever the question of a constitutional amendment or other question is so submitted to the vote of the people, such questions shall be printed

277 See Tenn. Public Acts (1935) chs. I27 and 128 , which are concerned with the 1935 proposal to call a convention. The proposal was not submitted to a vote but Chapter I28, Section I, assumed that the convention would be called if a majority of the yoters participating in the special election provided in Chapter 127 cast their ballots in favor of a convention. It was not deemed necessary to secure a favorable vote that would constitute a majority of the vote cast for the governor or representatives at any preceding or succeeding general election. Also observe that Chapter I28, Section 12, provided for the work of the convention to be submitted at the general November election in I936. The work would be ratified if approved by "a majority voting on the question." 
upon the ballot after the list of candidates, followed by the words 'yes' and 'no,' so that the voter can intelligently vote his preference by making a cross mark $(X)$ opposite the proper word." ${ }_{278}$ As shown by the voting in Illinois and Ohio for a short time following $189 \mathrm{r},{ }^{279}$ this is apparently the most obscure place on a ballot for constitutional propositions. But one may be permitted to guess that this consideration is not very important in Tennessee, since its ballot appears to be a short one. To begin with, that state does not elect by a popular vote as many officers as does Illinois, and those elected by the voters are divided between the two general elections in August and November of even-numbered years. ${ }^{280}$ "The ballot shall not be less than eleven nor more than thirteen inches wide." ${ }^{128}$ The length does not appear to be specified, but the relatively small number of candidates and propositions that appear on the ballot seems to make it clear that the ballot is short. Thus, it is not believed that placing constitutional propositions at the foot of the ballot has caused such a handicap as occurred in Illinois and Ohio. Furthermore, the Tennessee General Assembly can alter the position of constitutional propositions on the ballot. This was done in $1903^{282}$ for the submission of seven amendments in I904.

Also, it should be remembered that Tennessee in I870 did not embody in its constitution as much unessential detail as Illinois. Its constitution is not so sadly out of date as the Illinois constitution..$^{283}$

It is possible but not likely that the elections in the even years were special elections. In considering the percentage figures it should be kept in mind that the total vote at the special elections was not given. The basis for figuring the percentages is the vote for governor, and a governor is elected at a general, and not at a special, election.

Wyoming-Article XX, Section $I^{284}$ of the constitution of Wyoming

${ }^{278}$ Tenn. Code Ann. (Michie, I938) § 205I. This section was first enacted in I890 and $189 \mathrm{I}$.

${ }^{279}$ See note 21 I supra.

${ }^{280}$ There is no lieutenant-governor. The secretary of state, treasurer, comptroller, and state board of elections are elected by the two Houses of the General Assembly. Some local officers are elected by the county court. See note 278 supra, $\$$ Ig०3, I904, I9II, I9I5, Igrg.

${ }^{38 x}$ See note 278 supra.

${ }^{282}$ See note 266 supra.

${ }_{28}$ Combs, 32 Am. Pol. Sci. Rev. 514, 5 I5 (1938).

${ }_{28}$ "Any amendment or amendments to this constitution may be proposed in either branch of the legislature, and, if the same shall be agreed to by two-thirds of all the members of each of the two houses, voting separately, such proposed amendment or amendments shall, with the yeas and nays thereon, be entered on their journals, and it shall be the duty of the legislature to submit such amendment or amendments to the electors of the state at the next general election, and cause the same to be published without delay for at least twelve (I2) consecutive weeks, prior to said election, in at least one newspaper or general circulation, published in each county, 
provides that a proposed amendment of the constitution, if agreed to by two-thirds of all the members of each of the two Houses, voting separately, is adopted if it is ratified by "a majority of the electors" at the next general election. The Supreme Court of Wyoming interpreted this provision to mean that a proposed amendment was not ratified even though it had received the yes vote of a majority of those voting on the amendment, when this yes vote was less than a majority of the total vote cast at the general election at which the amendment was submitted. ${ }^{285}$ The language of the court is rather striking in stating that an amendment to be ratified must secure a majority of all the electors, and that the word "electors" in cludes not only those who vote but also those who are qualified to vote, yet fail to exercise their right of franchise. It is remarkable, in view of this language, that no subsequent litigation has arisen with reference to amendments of the Wyoming constitution which have been declared adopted. The administrative action of declaring certain proposed amendments adopted has been based upon the theory that a proposed amendment is ratified, if the yes vote for it is a majority of the total vote cast at the particular general election to which the amendment has been submitted. But it seems to be clear in American voting that at no time is the total vote cast at a particular election equal to the total number of those qualified to vote at that election.

It would be exceedingly difficult, if not for practical purposes impossible, to determine the total number of electors in Wyoming. In order to be an elector in Wyoming, ${ }^{286}$ a person must be at least twenty-one years of age and a citizen of the United States; he must be a resident of the state one year, and of the county sixty days, preceding the election; he must not be an idiot or insane; he must not be one who has been convicted of an infamous crime, unless he has been restored to his civil rights; and he must be one who can read the Wyoming constitution, unless prevented by physical disability. Registration is also required, unless the failure is caused by sickness or absence. With these qualifications, it is not possible to understand how the total number of electors in Wyoming on a particular day could be known short of an investigation that would be remarkable for its

and if a majority of the electors shall ratify the same, such amendment or amendments shall become a part of this constitution.

"Sec. 2. If two or more amendments are proposed, they shall be submitted in such manner that the electors shall vote for or against each of them separately."

Does "two-thirds of all the members" mean two-thirds of the members elected?

${ }^{285}$ State v. Brooks, I7 Wyo. 344, 352 et seq., 99 Pac. 874 (rgog). See ro Univ. Chi. L. Rev. 142, I44, n. I0 (1943).

${ }^{286}$ Wyo. Const. art. 6, $\$ 8 \mathrm{I}-\mathrm{I} 2$ inc. 
length and difficulty, and then for its subsequent futility. Apparently, therefore, administrative officials in Wyoming have applied the decision of the Wyoming Supreme Court in the Brooks case in the only practical way in which it can be applied. Apparently, also, if the proposition has been presented to lawyers concerning a contest of amendments which have been declared to be adopted, they have concluded that the Wyoming Supreme Court would probably not insist upon a rigid adherence to the language used in the Brooks case.

The result of these observations is that Wyoming, in the adoption of constitutional amendments, is in the same category as Mlinois, but, as will be later observed, the voters in. Wyoming generally have shown more interest in voting upon constitutional amendments than have the voters in Tllinois. Moreover, there is no limit in Wyoming on the number of amendments that may be submitted at a particular election.

Article XX, Section $3{ }^{287}$. of the Wyoming constitution provides for the calling of a constitutional convention. In'order to do so, however, twothirds of the members elected to each branch of the legislature must recommend a convention to the electors. If, at the next general election, "a majority of all the electors voting at.such election" vote for a convention, then the next legislature shall provide for a convention. It will be observed that this provision makes certain what is left uncertain in Section I concerning amendments. For it is expressly provided that the majority to secure a convention must be a majority of all the electors voting at a general election, not a majority of all the electors in the state, whether voting or not. Also it will be observed that Section 3 places Wyoming in the same class as. Ilinois for the purpose of securing a constitutional convention.

A constitutional convention has not been assembled in Wyoming since the convention that framed, its one and only constitution, just prior to its admission to statehood: Section 4 of Article XX provides briefly as follows: "Any constitution adopted by such convention shall have no validity until it has been submitted to and adopted by the people." This provision by itself seems to contemplate that a constitutional convention shall confine its work to framing an entirely new constitution. If it should be so construed, Section 4 is likely to prove to be unfortunate in its language. The

${ }^{287}$ "Whenever two-thirds of the members elected to each branch of the legislature shall deem it necessary to call a convention to revise or amend this constitution, they shall recommend to the electors to vote at the next general election for or against a convention, and if a majority of all the electors voting at such election shall have voted for a convention, the legislature shall at the next session provide by law for calling the same; and such convention shall consist of a number of members, not less than double that of the most numerous branch of the legislature." 
adoption of an entirely new constitution by a single vote is seldom required these days, and under modern conditions it is very difficult to obtain such action. To be highly useful, a constitutional convention should be permitted to submit amendments to the existing constitution. Section 3 , however, provides for a convention "to revise or amend this constitution." This language may be sufficient to avoid the difficulties just mentioned.

It will also be observed that Section 4 contains no expression as to how the new constitution is to be submitted, or by what majority it must be ratified. It is one thing to submit a new constitution at a special election, and quite another thing to submit it at a general election. Since there is no restriction upon submittal at a special election or upon adoption by a majority of those voting on the question at either a general or a special election, a guess is ventured that these things would be within the power of a constitutional convention. ${ }^{288}$

Aside, however, from constitutional provisions, there is a provision in the Wyoming statutes concerning special elections, that may be of considerable importance even though, so far as is known, it has not been used in Wyoming. Section $36-204^{289}$ provides: "Whenever any question is to be brought before and decided by the electors of Wyoming, the governor may call a special election, which shall be conducted the same as a special election called to fill a vacancy in the office of representative in Congress." "Any question" would seem to include constitutional propositions, whether a legislatively proposed amendment or a proposed new constitution. But the inclusion of such an amendment would seem to conflict with Section I of Article XX of the constitution, which provides that a legislatively proposed amendment shall be submitted "at the next general election." In the absence of any interpretation of Section 36-204, it is concluded that it would not be possible to submit such a proposed constitutional amendment in Wyoming at a special election. However, it is believed that this section would permit the submission of a new constitution, and possibly amendments proposed by a constitutional convention, under Section 3

${ }^{288}$ The Wyoming constitution was adopted at a special election on the first Tuesday in November, I889. The official ballot contained: "For the constitution-Yes. No." and the following instruction: "All persons who desire to vote for the constitution may erase the word 'No.' All persons who desire to vote against the constitution may erase the word 'Yes." But there was an alternative provision: "Any person may have printed or written on his ballot only the words: 'For the Constitution' or 'Against the Constitution,' and such ballots shall be counted for or against the constitution accordingly." It would seem that this alternative provision made it possible for parties, groups, and individuals, to prepare and distribute the type of ballot they desired. See Art. XXI, $\$ 7$.

${ }^{289}$ Wyoming R. S. I93r. 
of Article XX of the constitution, to a special election. If so, Wyoming may have a way out if it ever finds itself in a constitutional bog similar to the one into which the great state of Mllinois has sunk.

Chapter 27 of the Wyoming statutes ${ }^{290}$ provides for the mechanics by which legislatively proposed constitutional amendments are to be submitted to the electors and the method of voting upon them. Section 27Io6 provides that there shall be a separate official ballot for the proposed amendments. It is also provided that the paper upon which the ballot is to be printed is to be the same in color and quality as the regular official ballot containing the names of candidates. It is also provided that this separate ballot shall contain each proposed amendment, if there is more than one, in the order of its number, and the subject of it and the words "yes" and "no" so arranged that a voter can make his choice by marking a cross following the word which expresses his wishes. The "proper election officer" has the duty to deliver this separate ballot to the voter "and to see that the same is returned by such voter and deposited in a separate ballot box provided for that purpose." Despite this command, it will be observed that an excessive number of the voters have not voted on constitutional amendments, except on the question of prohibition.

This plan of using a separate ballot to vote on constitutional amendments appears to have first come into the Wyoming statutes in I909. ${ }^{29 x}$ Prior to 1909 , the statute enacted in $1895,{ }^{292}$ and later placed in the Wyoming Revised Statutes of $18999^{293}$ provided that constitutional amendments should be placed on the "official" ballot. By this was meant the ballot that contained the names of the candidates. This is made clear by Section 289 , R. S. 1899 , which, after providing for printing the names of the candidates on the ballot, states: "Fourth-Any proposed constitutional amendments or other questions to be submitted to the electors for popular vote, shall be printed at the foot of the ballot in such convenient place as to be readily distinguishable." All known experience, however, demonstrates that placing amendments "at the foot of the ballot" made these amendments very obscure to most voters. ${ }^{294}$ And. in Wyoming the amendments submitted before the separate ballot law was passed were

290 Ibid.

${ }^{292}$ Session Laws of Wyoming 1909, ch. 22, p. 28. This appears in the rgro Revised Statutes as Section 3594, which seems to conflict with Section 2184 (Fourth), which was the same as Section 289 of R. S. I899. This seeming conflict was apparently corrected by Session Law IgIT, ch. 5I. $^{\text {I }}$

${ }^{292}$ Session Laws of Wyoming, 1895, ch. $49, \S 6$.

293 Division one, title 21, ch. 4, § 2704 .

294 Compare the experience in Illinois and Ohio, supra, note 211. 
neglected and not voted upon by large percentages of the voters. The success that Wyoming has had has followed the enactment of the separate ballot law, and this is another item of evidence to show the value of a separate ballot for constitutional propositions.

It is also interesting that the Wyoming legislature, in $x 9 \mathrm{I} r$, in submitting a proposed initiative and referendum amendment provided that it should be submitted on the "general ballot upon which are the names of the candidates for offices at the next general election." ${ }^{295}$ No provision was made as to the portion of the general ballot on which this amendment should appear, and where it appeared, whether at the foot or elsewhere, is not known. The amendment received strong support. The percentage of voters (8.r per cent) who voted against it was small. But the percentage of voters who did not vote on the amendment (43.2 per cent) was almost as large as the percentage who voted yes. It seems to be a plausible guess that the initiative and referendum amendment would have been adopted if it had been submitted on a separate ballot.

After an amendment is adopted the governor shall issue his proclamation announcing that fact.

Table $2 x$ presents the facts concerning legislatively proposed constitutional amendments in Wyoming. ${ }^{296}$ A consideration of this table discloses that twenty-nine amendments were submitted to the voters. Twelve were ratified and thus adopted. Only three were defeated; but fourteen were not adopted. Thus, the Wyoming voters, despite their restrictive manner of adopting amendments, have ratified better than 4I per cent of those submitted. Why have they been able to do this while Illinois voters have sunk into a constitutional bog? The main answer seems to be that usually a larger percentage of the Wyoming voters are interested in, and vote upon, constitutional amendments. But it will be observed that, aside from schools, tax and debt increasing amendments, when not involving

295 Session Laws of Wyoming, I9Ir, ch. 52, § 3 .

${ }^{296}$ This table was mainly compiled from information contained in the official directory issued each odd-numbered year by the Wyoming Secretary of State. Additional information was also obtained from Dodd, op. cit. supra note ro, at 344, from the Wyoming Session Laws and Revised Statutes, and from Lester C. Hunt and Mart T. Christensen, Secretaries of State of Wyoming. It is clear from these sources that Wyoming executives and legislative officials interpret the Wyoming constitution to mean that an amendment to it is ratified if it has received a majority of the total vote cast at the general election at which the amendment is submitted. The total number of electors existing in the state at the time of the general election does not enter in to their calculations. The official directories vary somewhat. Some state the total vote at the elections and some state merely the vote necessary to adopt a particular amendment. In the latter event by subtracting one from the figure and multiplying the result by two, the total vote is obtained, except, it seems, where the necessary vote is not divisible by two. In that event, only a half of one is to be subtracted before multiplying by two. 
TABLE 21

\begin{tabular}{|c|c|c|c|c|}
\hline $\begin{array}{l}\text { Year, Total Vote Cast } \\
\text { at Election, and } \\
\text { Description of } \\
\text { Proposed Amendment }\end{array}$ & $\begin{array}{l}\text { Vote for } \\
\text { Proposed } \\
\text { Amendment }\end{array}$ & $\begin{array}{c}\text { Vote against } \\
\text { Proposed } \\
\text { Amendment }\end{array}$ & $\begin{array}{l}\text { Voting at } \\
\text { Election } \\
\text { but Not } \\
\text { Voting for } \\
\text { or against } \\
\text { Proposed } \\
\text { Amendment }\end{array}$ & Result \\
\hline $\begin{array}{l}\text { x900: Total vote } 25,459 \\
\text { Permitting counties to } \\
\text { refund indebtedness } \\
\text { in excess of consti- } \\
\text { tutional limitation }\end{array}$ & $\begin{array}{c}5,435 \\
(2 \mathrm{x} .4 \%)\end{array}$ & $\begin{array}{l}2,170 \\
(8.5 \%)\end{array}$ & $\begin{array}{l}17,853 \\
(70.1 \%)\end{array}$ & Not adopted \\
\hline $\begin{array}{l}\text { I904:297 Total vote } 30,64 \mathrm{r} \\
\text { Increasing salaries of } \\
\text { judges }\end{array}$ & $\begin{array}{c}5, \mathrm{x} 26 \\
(\mathrm{r} 6.7 \%)\end{array}$ & $\begin{array}{l}\text { II }, \text { I35 } \\
(36.4 \%)\end{array}$ & $\begin{array}{c}14,380 \\
(46.9 \%)\end{array}$ & Defeated \\
\hline $\begin{array}{l}\text { I908: Total vote } 37,56 \mathrm{~T} \\
\text { Constituency of state } \\
\text { board of equalization }\end{array}$ & $\begin{array}{l}\text { I2,I6o } \\
(32.4 \%)\end{array}$ & $\begin{array}{l}1,363 \\
(3.6 \%)\end{array}$ & $\begin{array}{c}24,038 \\
(64.0 \%)\end{array}$ & Not adopted \\
\hline $\begin{array}{l}\text { I9ro: Total vote } 37,926 \\
\text { Create state board of } \\
\text { equalization }\end{array}$ & $\begin{array}{c}24,429 \\
(64.4 \%)\end{array}$ & $\begin{array}{c}4,94 \mathrm{I} \\
(\mathrm{I} 3.0 \%)\end{array}$ & $\begin{array}{c}8,550 \\
(22.6 \%)\end{array}$ & Adopted \\
\hline $\begin{array}{l}\text { rgre: Total vote } 42,296 \\
\text { Initiative and referen- } \\
\text { dum }\end{array}$ & $\begin{array}{c}20,579 \\
(48.7 \%)\end{array}$ & $\begin{array}{c}3,446 \\
(8.1 \%)\end{array}$ & $\begin{array}{l}I 8,27 I \\
(43.2 \%)\end{array}$ & Not adopted \\
\hline $\begin{array}{l}\text { I9r4: Total yote } 44,877 \\
\text { Workmen's compensa- }\end{array}$ & 24,258 & 3,915 & 16,704 & -Adopted \\
\hline $\begin{array}{l}\text { tion } \\
\text { Sixty-day session for } \\
\text { legislature }\end{array}$ & $\begin{array}{l}(54.0 \%) \\
16,996 \\
(37.8 \%)\end{array}$ & $\begin{array}{r}(8.7 \%) \\
8,479) \\
(18.9 \%)\end{array}$ & $\begin{array}{l}(37.3 \%) \\
19,402 \\
(43.3 \%)\end{array}$ & Not adopted \\
\hline $\begin{array}{l}\text { Special tax on livestock } \\
\text { to destroy wild ani- } \\
\text { mals }\end{array}$ & $\begin{array}{l}20,4 \mathrm{rg} \\
(45.5 \%)\end{array}$ & $\begin{array}{r}8,331 \\
(18.5 \%)\end{array}$ & $\begin{array}{l}16,127 \\
(36.0 \%)\end{array}$ & Not adopted \\
\hline $\begin{array}{l}\text { Donations; internal im- } \\
\text { provements; state } \\
\text { work on highway }\end{array}$ & $\begin{array}{c}16,88 z \\
(37 \cdot 5 \%)\end{array}$ & $\begin{array}{c}7,507 \\
(\mathrm{I} 7.0 \%)\end{array}$ & $\begin{array}{c}20,488 \\
(45 \cdot 5 \%)\end{array}$ & Not adopted \\
\hline $\begin{array}{l}\text { I9x6: Total vote } 54,080 \\
\text { Authorizing investment } \\
\text { of state public school } \\
\text { funds in farm }\end{array}$ & $\begin{array}{l}41,798 \\
(77 \cdot 3 \%)\end{array}$ & $\begin{array}{c}3,86 \mathrm{I} \\
(7 . \mathrm{x} \%)\end{array}$ & $\begin{array}{c}8,42 I \\
(15.6 \%)\end{array}$ & Adopted \\
\hline $\begin{array}{l}\text { Construction and im- } \\
\text { proyement of state } \\
\text { highways }\end{array}$ & $\begin{array}{l}43,643 \\
(80.8 \%)\end{array}$ & $\begin{array}{l}2,987 \\
(5 \cdot 5 \%)\end{array}$ & $\begin{array}{c}7,450 \\
( \pm 3 \cdot 7 \%)\end{array}$ & Adopted \\
\hline $\begin{array}{l}\text { Igr8: Total vote } 44,338 \\
\text { Prohibition }\end{array}$ & $\begin{array}{c}31,439 \\
(71.0 \%)\end{array}$ & $\begin{array}{c}\text { Io, 200 } \\
(22.9 \%)\end{array}$ & $\begin{array}{c}2,699 \\
(6.1 \%)\end{array}$ & Adopted \\
\hline $\begin{array}{l}\text { Special tax on livestock } \\
\text { for inspection, pro- } \\
\text { tection, and in- } \\
\text { demnity }\end{array}$ & $\begin{array}{c}22,011 \\
(49.6 \%)\end{array}$ & $\begin{array}{l}10,499 \\
(23.7 \%)\end{array}$ & $\begin{array}{l}\text { II,828 } \\
(26.7 \%)\end{array}$ & Not adopted \\
\hline
\end{tabular}

297 Dodd, op. cit. supra note Io, at 344, states that the total I904 vote was 30,909 ; the I907 Wyoming official directory states $3^{\mathrm{r}, 567}$; and the $\mathrm{I} 9 \circ 9$, I9II, IgI3, and I9I5 directories state 30,64 r. 
TABLE 21-Continued

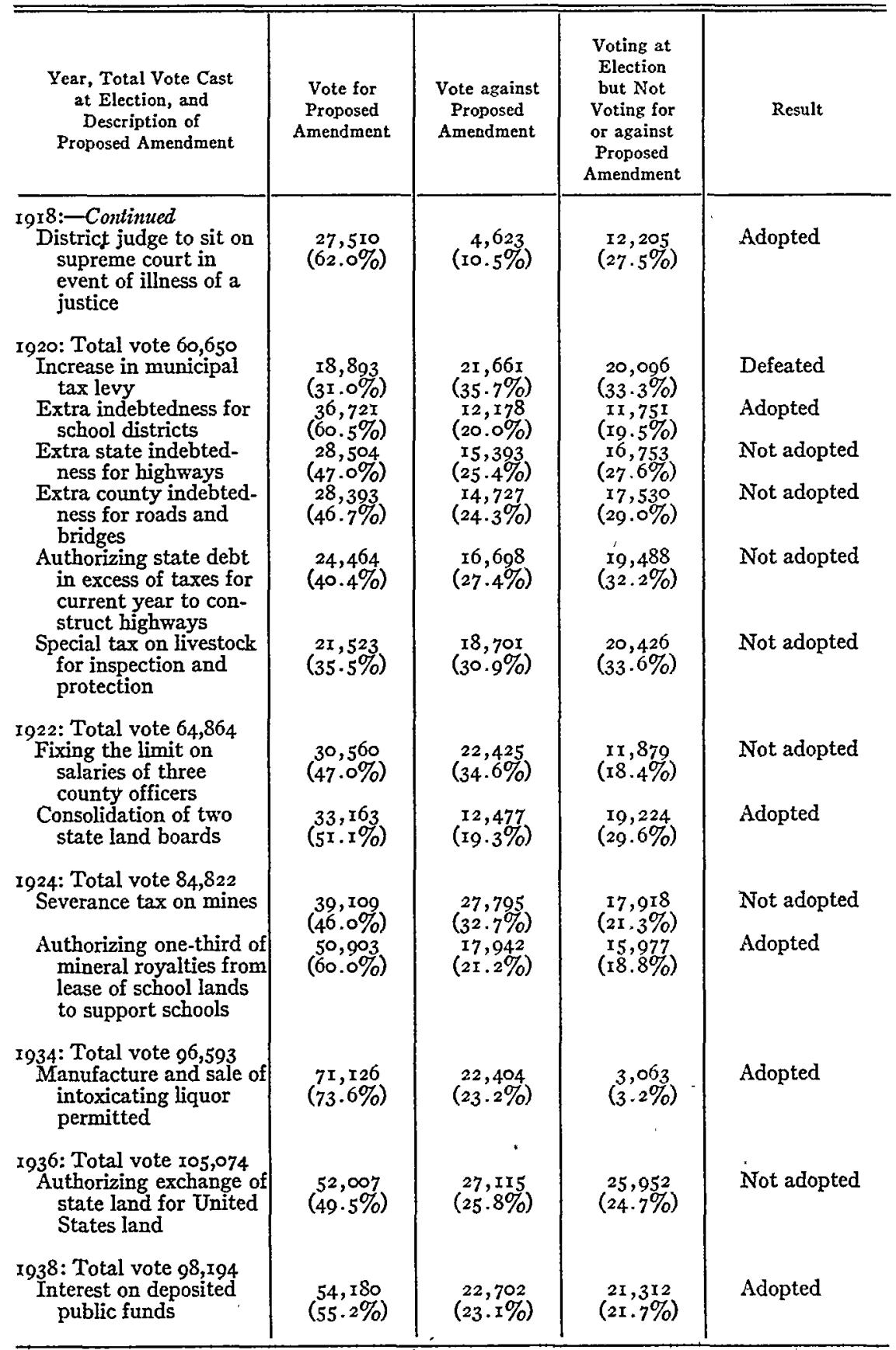


TABLE 21-Continued

\begin{tabular}{|c|c|c|c|c|}
\hline $\begin{array}{l}\text { Year, Total Vote Cast } \\
\text { at Election, and } \\
\text { Description of } \\
\text { Proposed Amendment }\end{array}$ & $\begin{array}{l}\text { Vote for } \\
\text { Proposed } \\
\text { Amendment }\end{array}$ & $\begin{array}{l}\text { Vote against } \\
\text { Proposed } \\
\text { Amendment }\end{array}$ & $\begin{array}{c}\text { Voting at } \\
\text { Election } \\
\text { but Not } \\
\text { Voting for } \\
\text { or against } \\
\text { Proposed } \\
\text { Amendment }\end{array}$ & Result \\
\hline $\begin{array}{l}\text { I940: Total vote I } 13,942 \\
\text { Construction of internal } \\
\text { improvements for } \\
\text { conservation of wvater }\end{array}$ & $\begin{array}{c}62,87 x \\
(55.2 \%)\end{array}$ & $\begin{array}{r}29,389 \\
(25.8 \%)\end{array}$ & $\begin{array}{c}21,682 \\
(19.0 \%)\end{array}$ & Adopted \\
\hline $\begin{array}{l}\text { Salaries of county } \\
\text { officers }\end{array}$ & $\begin{array}{c}37,847 \\
(33.2 \%)\end{array}$ & $\begin{array}{c}53,898 \\
(47.3 \%)\end{array}$ & $\begin{array}{c}22, \mathrm{rg} 7 \\
(\mathrm{x} 9.5 \%)\end{array}$ & Defeated \\
\hline
\end{tabular}

school financing, have not been generally adopted. Neither have amendments concerning official salaries. Wyoming may yet regret its restrictive provision on the adoption of amendments.

\section{GENERAL CONCLUSIONS}

By one method or another Alabama, Arkansas, Indiana, Nebraska, and Ohio have left the group of states which have the restrictive and rigid requirement that in order to amend their constitutions, it is necessary for a proposed amendment to secure the favorable vote of a majority of all electors who vote for any person or proposition at a general election. These states have joined the vast majority of the states which permit an amendment to be adopted, if it secures a favorable majority of those who vote on the particular amendment. This method is adhered to by forty states. Delaware permits amendment by the action of its legislature without the requirement of popular ratification. On the other hand, New Hampshire has no provision for legislatively proposed amendments; but it provides for constitutional conventions on a basis that appears to be distinctive to New Hampshire.

The remaining six states-Mllinois, Minnesota, Mississippi, Oklahoma, Tennessee, and Wyoming - generally require a legislatively proposed constitutional amendment to secure a favorable majority of all electors who vote in a general election for any person or proposition. The peculiarities in these six states have already been discussed. Except for certain types of amendments, Wyoming has had no great cause for grief, for the simple reason that more Wyoming voters have taken an interest in their governmental problems than have voters in Illinois. Minnesota has had less success with the restrictive method than Wyoming; but, except for certain types of amendments, its success has been fair, due to the interest of its 
voters, a separate ballot, no limit on the number of amendments, repeated submission of them, and the ease with which its legislature can pass an amendment to the voters.

Oklahoma apparently would be in about the same sad status as Mlinois if it had not been for the device of submitting amendments at special elections. That has been the main factor in preventing Oklahoma from sinking into a constitutional bog.

Mississippi is in a class by itself. The fate of constitutional amendments is determined in that state by what amounts to a special election, apparently attended in the main by the very small number of voters who are particularly interested in political affairs and who apparently have nothing to decide that is seriously contested except the fate of these constitutional amendments.

Tennessee takes the ribbon, whatever color it may be, for the most rigid and restrictive provision on the adoption of legislatively proposed amendments to its constitution. But it has a very easy way to constitutional reform by summoning a constitutional convention whenever it wishes to make use of it. There is no occasion to force the voters to modernize their constitution if they are well satisfied with what they have. And that appears to have been the case in Tennessee.

Illinois, everything considered, is in the worst position of any state in the Union. A majority of its voters who have any ideas to express have frequently shown that they think that their constitution is in need of a general revision. But, owing to the rigid and restrictive provisions for a revision or amendment, Illinois flounders around in its constitutional morass. It is a ridiculous spectacle for what is supposed to be one of the great states in the United States. Only one judgment can be uttered: Illinois has been politically backward and heaven alone knows when it will become ashamed of itself and exhibit political astuteness. There are ways out of the morass whenever Illinois secures the political leadership that can overcome the forces that believe in a relatively static society.

\section{APPENDIX A}

Instead of setting forth the citations of the sections of all state constitutions which deal with amendment and constitutional conventions, it has been decided to refer to Vol. III of the New York State Constitutional Convention Committee ( 1938 ), which contains the constitutions of the states and United States, and also to the Book of the States (I94I-42), published by The Council of State Governments, pp. 45-55. 
APPENDTX B

\begin{tabular}{|c|c|c|c|c|c|c|c|c|}
\hline \multirow[b]{2}{*}{ State } & \multicolumn{2}{|c|}{$\begin{array}{c}\text { LegISLatIVE } \\
\text { Proposal }\end{array}$} & \multirow[b]{2}{*}{$\begin{array}{l}\text { INITIA- } \\
\text { IIVE }\end{array}$} & \multicolumn{2}{|c|}{ RATIFICATION } & \multicolumn{2}{|c|}{ Convention MEtaod } & \multirow{2}{*}{$\begin{array}{c}\text { POPULAR } \\
\text { RATIFICATION } \\
\text { OF } \\
\text { CONVENIION'S } \\
\text { WORK } \\
\text { (8) }\end{array}$} \\
\hline & $\begin{array}{l}\text { First } \\
\text { Legis- } \\
\text { lature } \\
\text { (x) }\end{array}$ & $\begin{array}{l}\text { Second } \\
\text { Legis- } \\
\text { Iature } \\
\text { (2) }\end{array}$ & & $\begin{array}{c}\text { Major- } \\
\text { ity } \\
\text { upon } \\
\text { Issue } \\
\text { (4) }\end{array}$ & $\begin{array}{l}\text { Major- } \\
\text { ity at } \\
\text { Elec- } \\
\text { tion } \\
(5)\end{array}$ & $\begin{array}{c}\text { Legis- } \\
\text { lative } \\
\text { Vote } \\
(6)\end{array}$ & $\begin{array}{l}\text { Popular } \\
\text { Vote to } \\
\text { Call Con- } \\
\text { vention } \\
(7)\end{array}$ & \\
\hline 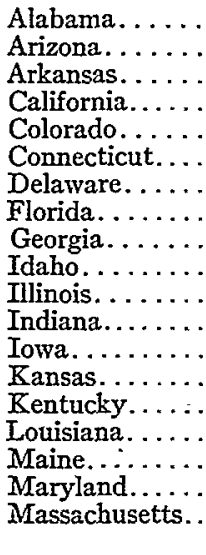 & $\begin{array}{l}3 / 5 \\
M \\
M \\
2 / 3 \\
2 / 3 \\
5 \\
2 / 3 \\
3 / 5 \\
2 / 3 \\
2 / 3 \\
2 / 3 \\
M \\
M \\
2 / 3 \\
3 / 5 \\
2 / 3 \\
2 / 3 \\
3 / 5 \\
M^{2}\end{array}$ & $\begin{array}{l}2 / 3 \\
2 / 3\end{array}$ & $\begin{array}{l}\text { yes } \\
\text { yes } \\
\text { yes } \\
\text { yes }\end{array}$ & $\begin{array}{l}\text { yes* } \\
\text { yes } \\
\text { yes* } \\
\text { yes } \\
\text { yes } \\
\text { yes } \\
7 \\
\text { yes } \\
\text { yes } \\
\text { yes } \\
\text { yes* } \\
\text { yes } \\
\text { yes } \\
\text { yes } \\
\text { yes } \\
\text { yes } \\
\text { yes } \\
\text { yes }\end{array}$ & $\underset{*}{\text { yes }}$ & $\begin{array}{l}\mathrm{M}^{\mathrm{x}} \\
\mathrm{M} \\
\text { no pro } \\
2 / 3 \\
2 / 3^{4} \\
\text { no } \mathrm{pr} \\
2 / 3 \\
2 / 3 \\
2 / 3 \\
2 / 3 \\
2 / 3 \\
\text { no pr } \\
\mathrm{M}, \mathrm{R}^{\mathrm{xo}} \\
2 / 3 \\
\mathrm{M}-\mathrm{M}^{\mathrm{r}} \\
\text { no pr } \\
2 / 3 \\
\mathrm{R} \\
\text { no pr }\end{array}$ & 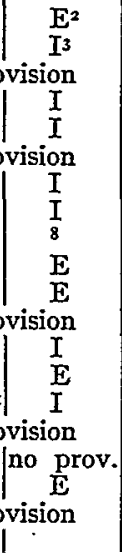 & $\begin{array}{l}\text { not required } \\
I \\
I \\
I \\
\text { not req. } \\
\text { not req. } \\
\text { not req. } \\
A^{9} \\
\text { I } \\
\text { not req. } \\
\text { not req. } \\
\text { not req. } \\
\text { not req. } \\
\text { I }\end{array}$ \\
\hline
\end{tabular}

* Formerly a majority of all voting at a general election was required; but, by either amendment or decision, this requirement was changed, so that now a majority of those voting on the issue is sufficient. " " $M$ " (majority) means that a majority of those elected to each house is required.

2 " $\mathrm{E}$ " (election) means that a majority of all voting at a general election is required to call a convention.

" "I" (issue) means that a majority of the voters voting upon the issue of whether or not a convention shall be called, or its work approved, is sufficient to call the convention, or approve the work.

4 In Colorado and Oregon the question of calling a convention may also be submitted to the electorate by initiative.

s In Connecticut the resolution to amend must pass the House of Representatives only by a majority vote. The Senate does not consider it at this time. It must pass both houses of the next legislature by a two-thirds vote.

- In Connecticut the proposed amendment must be approved by a majority of those participating in town meetings. But this is regarded as substantially the same as a majority voting upon the issue at a general election.

in Delaware no popular vote is necessary to ratify an amendment adopted by either the legislative or by the convention method.

- In Georgia a convention may be called by a two-thirds vote of the legislature without the need of that issue being submitted to the electorate.

" "A" (ambiguous) indicates that the constitutional provision regarding the popular vote upon the convention's work is ambizuously worded or otherwise not clear. For instance, in Idaho it is provided that "any Constitution

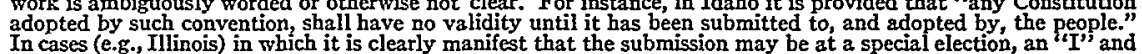
not an " $A$ " will appear in this column.

10 " $R$ " (routine submission) indicates that the constitution requires that at stated intervals the question of calling a convention to make or propose amendments be submitted to popular vote. The intervals are: Iowa, every ten years; Maryland, every twenty years; Michigan, every sixteen years; Missouri, every twenty years; New Hampshire, every seven years; New York, every twenty years; Ohio, every twenty years; and Oklahoma, every twenty years. The presence of both the "M," " $2 / 3$, , or " $3 / 5$ " and the " $R$," as in the case of Iowa and other states, indicates that a proposal to call a convention may be submitted to the voters at other times in addition to the required occasions.

"I In Kentucky a resolution to submit to the electorate the question of calling a convention must be passed by a majority vote of each house of two successive legislatures; and the electors voting for it must equal one-fourth of the electors who voted at the last preceding general election.

Iz In Massachusetts a legislatively proposed amendment must pass two successive legislatures by a majority of all members, voting not in each house but in a joint session of the two houses, before it is submitted to popular vote.

I3 In Massachusetts an amendment proposed by initiative petition may be withheld from popular vote, or may be amended and thus submitted by a three-fourths vote of all the members of two successive legislatures voting in a joint session of the two houses. If not amended and passed, or withheld by a three-fourths vote, an initiated amendment can be passed by one-fourth of two successive legislatures in joint session. The Massachusetts provisions are too complicated for full recitation here. 
APPENDIX B-Continued

\begin{tabular}{|c|c|c|c|c|c|c|c|c|}
\hline \multirow[b]{2}{*}{ State } & \multicolumn{2}{|c|}{$\begin{array}{c}\text { LEGISLATIVE } \\
\text { PROPOSAL }\end{array}$} & \multirow[b]{2}{*}{$\begin{array}{l}\text { INITIA- } \\
\text { TIVE }\end{array}$} & \multicolumn{2}{|c|}{ Ratification } & \multicolumn{2}{|c|}{ Convention Method } & \multirow{2}{*}{$\begin{array}{l}\text { POPULAR } \\
\text { RATIFICATION } \\
\text { OF } \\
\text { ConveNtION'S } \\
\text { WORK } \\
\text { (8) }\end{array}$} \\
\hline & $\begin{array}{l}\text { First } \\
\text { Legis- } \\
\text { lature } \\
\text { (I) }\end{array}$ & $\begin{array}{c}\text { Second } \\
\text { Iegis- } \\
\text { lature } \\
\text { (2) }\end{array}$ & & $\begin{array}{c}\text { Major- } \\
\text { ity } \\
\text { upon } \\
\text { Issue } \\
(4)\end{array}$ & $\begin{array}{l}\text { Maior- } \\
\text { ity at } \\
\text { Elec- } \\
\text { tion } \\
(5)\end{array}$ & $\begin{array}{c}\text { Legis- } \\
\text { lative } \\
\text { Vote } \\
(6)\end{array}$ & $\begin{array}{c}\text { Popular } \\
\text { Vote to } \\
\text { Call Con- } \\
\text { vention } \\
\text { (7) }\end{array}$ & \\
\hline 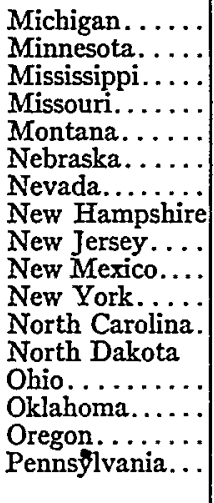 & $\begin{array}{l}2 / 3 \\
M \\
2 / 3 \\
M \\
2 / 3 \\
3 / 5^{16} \\
M \\
\text { no pro } \\
M \\
M^{29} \\
M \\
3 / 5^{20} \\
M \\
3 / 5 \\
M^{25} \\
M \\
M\end{array}$ & $\begin{array}{c}M \\
\text { vision } \\
M \\
M\end{array}$ & $\begin{array}{l}\text { yes } \\
\text { yes } \\
\text { yes } \\
\text { yes }\end{array}$ & $\begin{array}{l}\text { yes } \\
\text { yes } \\
\text { yes*17 } \\
\text { yes } \\
\text { yes } \\
\text { yes } \\
\text { yes } \\
\text { yes } \\
\text { yes } \\
\text { yes* } \\
\text { yes } \\
\text { yes }\end{array}$ & $\begin{array}{l}\text { yes } \\
\text { yes }^{55}\end{array}$ & $\begin{array}{l}\mathrm{R} \\
2 / 3 \\
\text { no pro } \\
\mathrm{M}, \mathrm{R} \\
2 / 3 \\
3 / 5 \\
2 / 3 \\
\mathrm{R} \\
\text { no } \mathrm{prc} \\
2 / 3 \\
\mathrm{M}, \mathrm{R} \\
2 / 3 \\
\text { no pro } \\
2 / 3 \mathrm{R} \\
\mathrm{M}, \mathrm{R} \\
\mathrm{M}^{22} \\
\text { no pro }\end{array}$ & 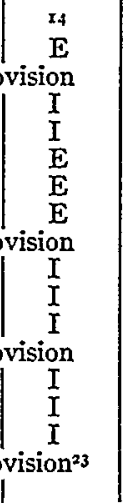 & $\begin{array}{l}\text { I } \\
\text { not req. } \\
\mathrm{I} \\
\mathrm{I} \\
\mathrm{I} \\
\text { not req. } \\
2 / 3 \mathrm{I}^{\mathrm{I}} \\
\mathrm{A} \\
\text { I } \\
\text { not req. } \\
\text { I } \\
\text { I } \\
\text { not req. }\end{array}$ \\
\hline
\end{tabular}

is In addition to a periodical submission of the question, Michigan provides that the question of the gezeral revision of its constitution shall be submitted "at such other times as may be provided by law." The convention is called if a majority of "such" electors "voting at such election" shall decide in favor of a convention. It would appear that this election could be a special election.

1s After an amendment has been adopted by the electors in Mississippi, the constitution provides that "it shall be inserted at the next succeeding session of the legislature as a part of the constitution and not otherwise." What would be the status of an amendment that was adopted but not inserted has not been determined.

${ }^{6}$ In Nebraska a resolution proposing a constitutional amendment, or the calling of a constitutional convention, must pass the unicameral legislature by a three-fifths vote.

i7 In Nebraska a proposed amendment to be ratified must receive more favorable votes than those opposed, but also the affirmative votes must be at least 35 per cent of the total vote cast at the election at which the proposed amendment is voted upon.

is In New Hampshire alterations proposed by a convention are submitted to the electorate at town meetings, and must be ratified by two-thirds of those voting for or against ratification before they become effective.

3In New Mexico legislatively proposed amendments dealing with specified sections concerning the elective franchise and education must be proposed by a three-fourths vote of each house of the legislature and ratifed by a "three-fourths vote of the electors yoting in the whole state and at least two-thirds of those voting in each county." Section $I$ of the amending article can only be changed by a constitutional convention.

20 See comment concerning North Carolina in Io Univ. of Chi. L. Rev. 142, I46 (1943).

ax In Oklahoma and Tennessee submission of legislatively proposed amendments may be at a special election. But in Oklahoma a special election cannot be held unless the legislature so votes by a two-thirds majority. The Oklahoma provisions are complicated. See the discussion supra.

22 See note 4 supra.

23 In both Pennsylvania and Rhode Island an interesting doctrine has been announced. In each state it has been held that, notwithstanding the failure of the constitution to provide for the calling of a convention to propose constitutional amendments or a new constitution, the legislature may provide for the calling of a convention. In Pennsylvania several steps must occur: ( $I$ ) the legislature passes a resolution taking the sense of the people as to whether a convention should be called; (2) a favorable popular vote is cast; (3) the legislature passes a resolution calling the convention and the election of delegates; (4) the amendments drafted by this convention are submitted to popular vote for approval or rejection. In Rhode Island the supreme court, in answer to questions propounded to it by the legislature under the advisory opinion provision of the state constitution, has ruled that the legislature may call a convention without first submitting to the voters the question as to whether one should be called. The delegates must be selected by a popular vote. The method of amendment provided for in the constitution was regarded as not exclusive. Sovereignty is in the people, and they have the inherent power to amend their constitution through their representatives in a convention and by ratifying the work of that body. Wells $\mathrm{v}$. Bain, 75 Pa. 39 , I5 Am. Rep. 563 (I874); Wood's Appeal, 75 Pa. 59 (I874); Armstrong v. King, 281 Pa. 207, 219, 222 , I26 Atl. 263 (1924); In re the Constitutional Convention, 55 R. I. 56, I78 Atl. 433 (I935), overruling In re the Constitutional Convention, 14 R. I. 649 (1883). 
APPENDTX B-Continued

\begin{tabular}{|c|c|c|c|c|c|c|c|c|}
\hline \multirow[b]{2}{*}{ State } & \multicolumn{2}{|c|}{$\begin{array}{c}\text { Legislative } \\
\text { Proposal }\end{array}$} & \multirow[b]{2}{*}{$\begin{array}{l}\text { INITIA- } \\
\text { TIVE }\end{array}$} & \multicolumn{2}{|c|}{ RATIFICATION } & \multicolumn{2}{|c|}{ CONVEntion Method } & \multirow{2}{*}{$\begin{array}{c}\text { PopUlar } \\
\text { RATIFICATION } \\
\text { OF } \\
\text { CONVENTION'S } \\
\text { WORK } \\
\text { (8) }\end{array}$} \\
\hline & $\begin{array}{c}\text { First } \\
\text { Legis- } \\
\text { lature } \\
\text { (I) }\end{array}$ & $\begin{array}{c}\text { Second } \\
\text { Legis- } \\
\text { lature } \\
\text { (2) }\end{array}$ & & $\begin{array}{c}\text { Major- } \\
\text { ity at } \\
\text { Elec- } \\
\text { tion } \\
(4)\end{array}$ & $\begin{array}{c}\text { Major- } \\
\text { ity } \\
\text { upon } \\
\text { Issue } \\
(5)\end{array}$ & $\begin{array}{c}\text { Iegis- } \\
\text { lative } \\
\text { Vote } \\
(6)\end{array}$ & $\begin{array}{l}\text { Popular } \\
\text { Vote to } \\
\text { Call Con- } \\
\text { vention } \\
(7)\end{array}$ & \\
\hline $\begin{array}{l}\text { Rhode Tsland... } \\
\text { South Carolina. } \\
\text { South Dakota. } \\
\text { Tennessee.... } \\
\text { Texas. . . . . . } \\
\text { Utah........ } \\
\text { Vermont. . . . } \\
\text { Virginia...... } \\
\text { Washington... } \\
\text { West Virginia. } \\
\text { Wisconsin..... } \\
\text { Wyoming..... }\end{array}$ & $\begin{array}{l}M \\
2 / 3 \\
M \\
M \\
2 / 3 \\
2 / 3 \\
27 \\
M \\
2 / 3 \\
2 / 3 \\
M \\
2 / 3\end{array}$ & $\begin{array}{l}M^{25} \\
2 / 3 \\
M \\
M\end{array}$ & & $\begin{array}{l}\text { yes }^{24} \\
\text { yes } \\
\text { yes } \\
\text { yes } \\
\text { yes } \\
\text { yes } \\
\text { yes } \\
\text { yes } \\
\text { yes } \\
\text { yes }\end{array}$ & yes & $\begin{array}{l}\text { no pr } \\
2 / 3 \\
2 / 3 \\
\mathrm{MI} \\
\text { no pr } \\
2 / 3 \\
\text { no pr } \\
\mathrm{M} \\
2 / 3 \\
\mathrm{M} \\
\mathrm{M} \\
2 / 3\end{array}$ & $\begin{array}{c}\text { vision } \\
E \\
E \\
I^{26} \\
\text { vision } \\
\text { E } \\
\text { vision } \\
\stackrel{I}{E} \\
\underset{I}{I} \\
\frac{I}{E}\end{array}$ & $\begin{array}{l}\text { not req. } \\
\text { not req. } \\
\text { not req. } \\
\mathrm{E} \\
\text { not req. } \\
\mathrm{A} \\
\mathrm{A} \\
\text { not req. } \\
\mathrm{A}\end{array}$ \\
\hline
\end{tabular}

“In Rhode Island a legislatively proposed amendment must be approved by three-fifths of the electors of the state present and voting thereon in town and ward meetings. See, also, note 23 supra.

${ }_{25}$ South Carolina has the unusual provision that to adopt a legislatively proposed amendment, which has been ratified by the electors, it is necessary for a majority of each branch of the next general assembly to ratify the same amendment.

${ }^{26}$ By reason of the decision in Derryberry v. State Board, 150 Tenn. 525, 266 S. W. I02 (I924).

m In Vermont an amendment must be proposed by the Senate and then pass the first legislature by a two-thirds vote of the Senate and a majority of the House. At the next legislature it must pass each house by a majority. Amendments may be proposed only once every ten years.

${ }^{28}$ The West Virginia provision is: "And such convention shall not be held unless a majority of the votes cast at such polls be in favor of calling the same." But the question can be submitted at a special election and apparently it cannot be submitted at a general election.

The material contained in this table and in the notes thereto has been taken from the texts of constitutional provisions and court opinions, and has been compared: (I) with information in an article entitled "Amendment and Revision of State Constitutions," by Charles C. Rohling, in the Annals of the American Academy of Political and Social Science, September, 1935, at 180-87; $(2)$ with The Book of the States (1941-42), The Council of State Governments; (3) with tables contained in an unpublished thesis by Rodney B. Chipp entitled, "Fundamental Attitude of the American People Regarding the Amending Process," (1938), Library of Congress Number J. K 2421 ; (4) with a mimeographed memorandum issued by the Illinois Agricultural Association; and (5) with Constitutions of the States and United States, New York State Constitutional Convention Committee (I938), vol. iii. 